\title{
Assessment of Very High-Temperature Reactors in Process Applications
}

Appendix II - VHTR Process Heat Application Studies
J. E. Jones
W. R. Gambill
R. H. Cooper
E. C. Fox
L. C. Fuller
C. C. Littlefield
M. D. Silverman

\section{OAK RIDGE NATIONAL LABORATORY}




\section{DISCLAIMER}

This report was prepared as an account of work sponsored by an agency of the United States Government. Neither the United States Government nor any agency Thereof, nor any of their employees, makes any warranty, express or implied, or assumes any legal liability or responsibility for the accuracy, completeness, or usefulness of any information, apparatus, product, or process disclosed, or represents that its use would not infringe privately owned rights. Reference herein to any specific commercial product, process, or service by trade name, trademark, manufacturer, or otherwise does not necessarily constitute or imply its endorsement, recommendation, or favoring by the United States Government or any agency thereof. The views and opinions of authors expressed herein do not necessarily state or reflect those of the United States Government or any agency thereof. 


\section{DISCLAIMER}

Portions of this document may be illegible in electronic image products. Images are produced from the best available original document. 


\title{
Printed in the United States of America. Available from National Technical Information Service U.S. Department of Commerce 5285 Port Royal Road, Springfield, Virginia 22161 \\ Price: P'rinted Copy $\$ 5.50 ;$ Microfiche $\$ 3.00$
}

\begin{abstract}
This report was prepared as an account of work sponsored by the United States Government. Neither the United States nor the Energy Research and Development Administration/United States Nuclear Regulatory Commission, nor any of their employees, nor any of their contractors, subcontractors, or their employees. makes any warranty. express or implied. or assumes any legal liability or responsib!lity for the accuracy. completeness or usefulness of any information, apparatus. product or process disclosed, or represents that its use would not infringe privately owned rights.
\end{abstract}


Contract No. W-7405-eng-26

ENGINEERING TECHNOLOGY DIVISION

ASSESSMENT OF VERY HIGH-TEMPERATURE REACTORS

IN PROCESS APPLICATIONS.

APPENDIX II - VHTR PROCESS HEAT APPLICATION STUDIES
J. E. Jones
W. R. Gambill
R. H. Cooper
E. C. Fox
L. C. Fuller
C. C. Littlefield
M. D. Silverman

Date Published: June 1977

\author{
Prepared by the \\ OAK RIDGE NATIONAL LABORATORY \\ Oak Ridge, Tennessee 37830 \\ operated by \\ UNION CARBIDE CORPORATION \\ for the \\ ENERGY RESEARCH AND DEVELUP'MENT ADMINISTRATION
}

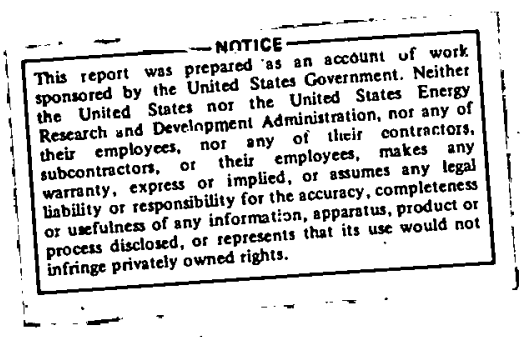


The complete report is composed of the following:

ORNL/TM-5242 - Assessment of Very High-Temperature Reactors in Process Applications

ORNL/TM-5409 - Evaluation of the Reactor System

(Appendix I)

ORNL/TM-5410 - Very High-Temperature Reactor Process Heat

(Appendix II) Application Studies

ORNL/TM-5411 - Engineering Evaluation of Process Heat Applications

(Appendix III) for Very High-Temperature Reactors 
FOREWORD . . . . . . . . . . . . . . . . . . . . . . v

ABSTRACT . . . . . . . . . . . . . . . . . . . . vii

INTRODUCTION . . . . . . . . . . . . . . . . . . . ix

1. PROCESS HEAT APPLICATIONS . . . . . . . . . . . . . . 1

1.1. Summary . . . . . . . . . . . . . . . . . . 1

1.1.1 Coal conversion ............... . 1

1.1.2 Nuclear steelmaking . . . . . . . . . . . 1

1.1.3 Petroleum refinery ............... 1

1.1.4 0il shale and tar sands . . . . . . . . . . 2

1.2 Coal Conversion ................... 2

1.2.1 Discussion of rationale for developing nuclear

process heat for coal conversion ....... 2

1.2.2 Evaluation of a coal liquefaction process using either a nuclear- or a fossil-heat source for reforming . . . . . . . . . . . 3

1.2.3 Conceptual design of a coal-steam gasification process heated by a gas-cooled reactor . . . . . 11

1.2.4 Hydrogen from water splitting - electrolytic and thermochemical - and its application to fuel synthesis . . . . . . . . . . . . . . 24

1.2.5 Advantages and disadvantages of nuclear coal conversion . . . . . . . . . . . 32

1.2.6 Conclusions and recommendations for nuclear coal conversion ... . . . . . . 34

1.3 Nuclear Steelmaking . . . . . . . . . . . . 35

1.4 Petroleum Refinery .. . . . . . . . . . . . . 37

1.5 0il Shale and Tar Sands ............. . 49

2. ENERGY STORAGE, TRANSPORT, AND PEAKING POWER

APPLICATIONS . . . . . . . . . . . . . . . . . . 57

2.1 Summary . . . . . . . . . . . . . . . 57

2.1.1 Introduction . . . . . . . . . . . . 57

2.1.2 Potential market ............. . 57

2.1.3 Conclusions . . . . . . . . . . . . 58

2.2 EVA-ADAM .................. 62

2.2.1 Results.................. . 68

2.2.2 Detailed system description . . . . . . . . . 71

2.3 Heat Transfer Salt . . . . . . . . . . . . . . 77

2.3.1 Heat source ................. . 78

2.3 .2 Salt ................... 78

2.3.3 System description .. . . . . . . . . 79

2.3.4 Economic analysis ........... . . 79 
3. MATERIALS REQUIREMENTS FOR PROCESS HEAT EXCHANGERS . . . . . 85

3.1 Steam Reforming . . . . . . . . . . . . . . 85

3.2 Steam-Coal Gasification . . . . . . . . . . . 86

3.3 High-Temperature Load-Carrying Capabilities . . . . . 87

3.4 Materials Compatibility . . . . . . . . . . . . 89

3.5 Thermochemical Hydrogen Production . . . . . . . . . 91

3.6 Summary . . . . . . . . . . . . . . . . . . 97

REFERENCES . . . . . . . . . . . . . . . . . 99 


\section{FOREWORD}

This is one of a series of reports on nuclear process heat. The overall summary is Assessment of Very High-Temperature Reactors in Process Applications (ORNL/TM-5242). Details and background information are presented in Appendix I - Evaluation of the Reactor System (ORNL/TM-5409); Appendix II - VHTR Process Application Studies (ORNL/TM-5410); and Appendix III - Engineering Evaluation of Process Heat Applications for VHTRS (ORNL/TM-5411). 
THIS PAGE

\section{WAS INTENTIONALLY LEFT BLANK}




\section{ABSTRACT}

A critical review is presented of the technology and economics for coupling a very high-temperature gas-cooled reactor to a variety of process applications. It is concluded that nuclear steam reforming of light hydrocarbons for coal conversion could be a near-term alternative and that direct nuclear coal gasification could be a future consideration. Thermochemical water splitting appears to be more costly and its availability farther in the future than the coal-conversion systems. Nuclear steelmaking is competitive with the direct reduction of iron ore from conventional coal-conversion processes but not competitive with the reforming of natural gas at present gas prices. Nuclear process heat for petroleum refining, even with the necessary backup systems, is competitive with fossil energy sources. The processing with nuclear heat of oil shale and tar sands 1 s of marginal economic importance. An analysis of peaking power applications using nuclear heat was also made. It is concluded that steam reforming methane for energy storage and production of peaking power is not a viable economic alternative, but that energy storage with a high-temperature heat transfer salt (HTS) is competitive with conventional peaking systems. An examination of the materials required in process heat exchangers is made. 
THIS PAGE

WAS INTENTIONALLY LEFT BLANK 


\section{INTRODUCTION}

In April 1974, the Energy Research and Development Administration (ERDA) authorized General Atomic Company, General Electric Company, and Westinghouse Astronuclear Laboratory to assess the available technology for producing process heat utilizing very high-temperature nuclear reactors (VHTRs). ${ }^{1-3}$ The final reports of this work were submitted in December 1974.

Oak Ridge National Laboratory (ORNL) was assigned a lead role in evaluating the vendor VHTR studies and assessing the application of VHTRs in a number of specific high temperature processes and in intermediate and peaking power generation.

This is an Appendix of a summary report entitled Assessment of Very High-Temperature Reactors in Process Applications (ORNL/TM-5242). The other two appendices are Evaluation of the Reactor System - Appendix I (ORNL/TM-5409) and Engineering Evaluation of Process Heat Applications for Very High-Temperature Nuclear Reactors - Appendix III (ORNL/TM-5411). This Appendix includes the discussion of process heat applications and peaking power applications. Each section is organized to present a discussion of the merits of the specific applications. 


\section{PROCESS HEAT APPLICATIONS}

\subsection{Summary}

A very wide range of process heat applications has been considered. Because of the diversity of process heat applications, it is not practical to present direct comparisons of the alternatives considered. All applications appear to be technically achievable with development of the VHTR.

\subsubsection{Coal conversion}

The major long-term process heat application of the VHTR is in synthetic fuels via coal conversion. As many as 132 3000-MW(t) VHTRs could be used in synthetic fuel production by the year $2030 .^{4}$ However, this application could not have a significant impact until after the year 2000 .

The most reasonable near-term use of the VHTR in coal conversion is its application in the steam reforming of light hydrocarbons. In the modified Hydrocarbon Research H-Coal process to produce crude liquids, the nuclear reformer application is economically competitive with the all-fossil plant and produces less environmental pollution. Direct coal gasification using nuclear heat is a promising nuclear coal-conversion application for the long term. This generally requires higher-temperature or catalyzed coal. Use of the VHTR to produce hydrogen for coal conversion via thermochemical or electrolytic water splitting is not economically competitive with hydrogen via coal gasification.

\subsubsection{Nuclear steelmaking}

Steelmaking via direct reduction using synthesis gas from a nuclearheated reformer appears to be competitive with the conventional coke-ovenblast-furnace process and with the direct reduction process using synthesis gae from a Koppers-Totzek gasifier. It is not competitive with synthesis gas from a conventional natural-gas reformer, when considering present natural gas costs.

Because of size mismatch the steel industry does not appear to represent a major market for the VHTR in number of units, but that market may be a very important one. The Japanese have launched a major program in nuclear steelmaking, allocating about $\$ 26$ million over a six-year period. Nuclear steelmaking technology may be required to keep the U.S. steel industry competitive in the future.

\subsubsection{Petroleum refinery}

The high-temperature gas-cooled reactor (HTGR) (or low-range VHTR) has been evaluated as a source of high-temperature process heat and steam for petroleum refining. Although the heat transfer system was 
made more complex (and expensive) by the necessity for a backup heat source to assure very high availability, heat can be delivered to the refinery for $\$ 1.91$ to $\$ 3.92$ per $10^{6} \mathrm{Btu}$. This appears to be in a competitive range with most fossil fuels for delivered energy cost.

\section{1 .4 Oil shale and tar sands}

The relative cost of oil.shale recovery using the VHTR appears to be marginally competitive with conventional alternatives. Potential benefits of the VHTR application are the $24 \%$ to $50 \%$ greater yield from the oil shale resource and the approximately $20 \%$ lower water requirement.

The market potential for the VHTR in shale oil recovery and processing is not projected to be significant at present. The market potential in tar sands recovery in the United States is nil, but potential applications in Canada, Venezuela, and Colombia could provide an export market.

\subsection{Coal Conversion}

\subsubsection{Discussion of rationale for developing nuclear process heat for coal conversion}

Nuclear conversion of coal to synthetic pipeline gas, synthesis gas, and liquid fuels is an option that will not be realized until the twenty-first century because the necessary reactor technology will not, in all probability, be demonstrated before 1995. However, the application of nuclear power to coal conversion could be of great importance. In the next century, possible limitations in the availability of fossil fuels could cause coal to be restricted to feedstock fur synthetics dedicated to transportation, chemicals, and consumer fuels. With the expected commercialization of a breeder reactor, which would provide nuclear resources in excess of our projected coal resources, the development of nuclear power for the conversion of coal could become an attractive and economic option.

For the conversion of coal to synthetic fuels, there are four processes that are amenable to the application of nuclear process heat:

1. Hydrogasification of coal. (This type of process has been studied and developed extensively in West Germany. ${ }^{5}$ )

2. Solution hydrocracking of coal. (General Atomic and Stone \& Webster have investigated the production of synthetic pipeline gas ${ }^{6}$ and hydrogen. ${ }^{7}$ )

3. Direct steam gasification of coal. (This type of process has also been studied and developed extensively in West Germany. ${ }^{5}$ )

4. Thermochemical and electrolytic production of hydrogen from water for coal conversion. 
This assessment was conducted as a preliminary analysis of the feasibility of nuclear coal conversion, rather than as an exhaustive investigation of all possible coal-conversion techniques. Because of this limited scope, only three specific processes were chosen for evaluation:

1. A modified H-Coal (solution hydrocracking) process which incorporates convective reforming with hot helium to produce crude liquids.

2. Gasification of coal in a steam-fluidized bed heated by helium in tubes immersed in the bed to produce synthesis gas $\left(\mathrm{H}_{2}+\mathrm{CO}\right)$.

3. The use of hydrogen and oxygen produced by thermochemical water splitting, using a nuclear energy source, to produce syncrude, methanol, and other products from coal.

These processes were felt to be sufficiently diverse to provide an overview of the coupling of nuclear reactors to provide process heat for coal conversion.

\subsubsection{Evaluation of a coal liquefaction process using either a nuclear- or a fossil-heat source for reforming}

The study of coal liquefaction via a nuclear- or a fossil-heat source was conducted under subcontract by United Engineers \& Constructors Inc. (UE\&C) and is reported separately. ${ }^{8}$ The results are summarized below. The study constitutes the preliminary design of a coal liquefaction plant that uses either a nuclear reactor or fuel gas produced in the plant as the primary heat source for the process. The process is based on a modified H-Coal process. The costs of products produced by these two processes are estimated and are compared with each other and with some competing products. A block flow diagram of the process is shown in Fig. 1.

The plant converts 60,000 tons per day of western Kentucky highvolatile-b-bituminous (hvbb) coal into liquid hydrocarbons with boiling points in the range of $180^{\circ}$ to $975^{\circ} \mathrm{F}$. Coker gas, a mixture of gaseous hydrocarbons with a heating value of $1080 \mathrm{Btu} / \mathrm{ft}^{3}$, is a coproduct of the nuclear-heated plant. The plant also produces salable quantities of ammonia, elemental sulfur, and a solid residue with a heating value of $8235 \mathrm{Btu} / \mathrm{lb}$. This solid residue (char) is relatively high in sulfur and ash but would be an acceptable fuel under some circumstances. Table 1 is a summary of the material requirements and the product quantities for the fossil- and nuclear-heated plants. In Table 2, these quantities are normalized to provide a basis for comparison with other processes:

The cost of the energy contained in the crude liquids ranges from $\$ 1.70$ to $\$ 4.06$ per $10^{6}$ Btu for the material and utility costs used in the evaluation. Coal was assumed to cost between $\$ 12$ and $\$ 42$ per ton; 
ORNL-DWG 76-11151

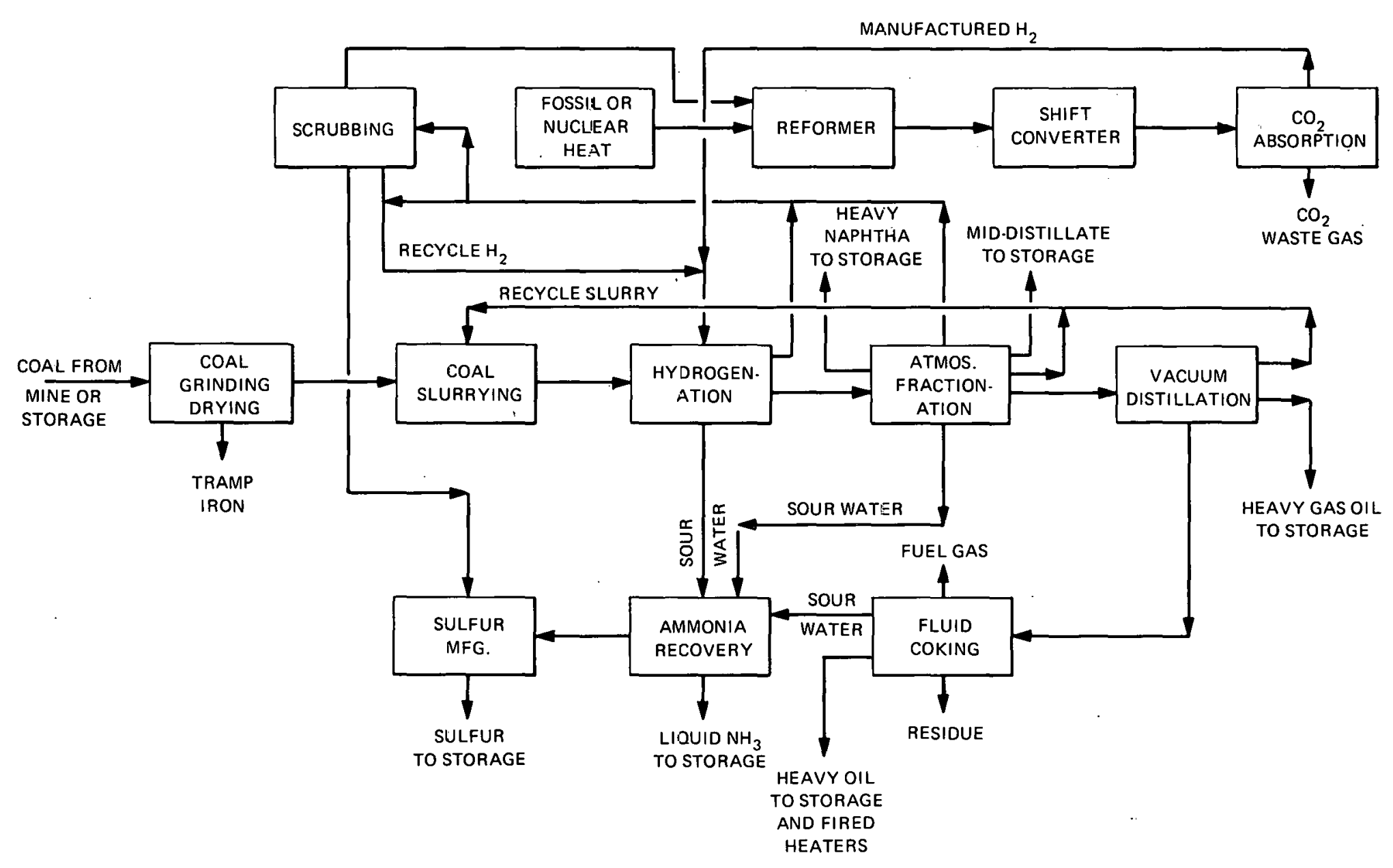

Fig. 1. Block diagram of the coal liquefaction process. 
Table 1. Plant operating characteristics

\begin{tabular}{|c|c|c|}
\hline Item & Fossil & Nuclear \\
\hline Plant size, crude liquids (Btu per day) & $923 \times 10^{9}$ & $1,033 \times 10^{9}$ \\
\hline Plant size, total product (Btu per day) & $1,114 \times 10^{9 a}$ & $1,305 \times 10^{9 b}$ \\
\hline Energy efficiency, \% & 78 & 78 \\
\hline Coal-use efficiency, \% & 78 & 90 \\
\hline Stream factor, days per year & 330 & 330 \\
\hline \multicolumn{3}{|c|}{ Materials } \\
\hline Coal ( $7.5 \%$ moisture), tons per day & 60,000 & 60,000 \\
\hline Water, tons per day & 150,000 & 150,000 \\
\hline Catalysts and chemicals, $\$$ per year & $21.2 \times 10^{6}$ & $21.2 \times 10^{6}$ \\
\hline \multicolumn{3}{|l|}{ Products } \\
\hline Heavy naphtha, Btu per day & $334 \times 10^{9}$ & $405 \times 10^{9}$ \\
\hline Middistillate, Btu per day & $298 \times 10^{9}$ & $298 \times 10^{9}$ \\
\hline Heavy oil, Btu per day & $247 \times 10^{9}$ & $286 \times 10^{9}$ \\
\hline Heavy gas oil, Btu per day & $44 \times 10^{9}$ & $44 \times 10^{9}$ \\
\hline Coker gas $(1080 \mathrm{Btu} / \mathrm{scf})$, Btu per day & & $52 \times 10^{9}$ \\
\hline Ammonia, tone per day & 441 & 441 \\
\hline Sulfur (elemental.), tons per day & 1,200 & 1,200 \\
\hline Char $(8,235 \mathrm{Btu} / 1 \mathrm{~b})$, tons per day & 11,518 & 13,280 \\
\hline \multicolumn{3}{|c|}{ Polzutants, tons per day } \\
\hline Sulfur dioxide & 113 & 28 \\
\hline Nitrogen oxides & 45 & 12 \\
\hline Particulates & 2.6 & 1.1 \\
\hline Solid waste & 1,128 & $494^{\circ}$ \\
\hline
\end{tabular}

$a_{\text {Includes char. }}$

$b$ Includes char and coker gas. 
Table 2. Normalized operating characteristics

\begin{tabular}{ccc}
\hline Item & Fossil & Nuclear \\
\hline Coal utilization, $1 \mathrm{~b} / 10^{6} \mathrm{Btup}^{\alpha}$ & 107.7 & 91.9 \\
Water use, tons per ton of coal & 2.51 & 2.51 \\
$1 \mathrm{~b} / 10^{6}$ Btup & 270.5 & 230.9
\end{tabular}

Products

\begin{tabular}{lcc} 
Heavy naphtha, bbl per ton of coal & 1.065 & 1.324 \\
Middistillate, bbl per ton of coal & 0.875 & 0.875 \\
Heavy gas oil, bbl per ton of coal & 0.114 & 0.114 \\
Heavy oil, bbl per ton of coal & 0.687 & 0.796 \\
Coker gas, scf per ton of coal & 0 & 802 \\
Ammonia, lb per ton of coal & 14.7 & 14.7 \\
Sulfur, lb per ton of coal & 40.0 & 40.0 \\
Char, tons per ton of coal & 0.192 & 0.221 \\
\hline
\end{tabular}

other cost assumptions are stated in Table 3. Figure 2 shows a breakdown of the product costs for the low- and high-cost bases. The differences between the nuclear- and fossil-heated costs are mostly in the costs of coal and capital. There is no significant difference between the total costs of the nuclear- and fossil-heated products (nuclear plant products are more costly by $1 \%$ to $6 \%$ ).

The costs per unit energy of the crude liquids compared with the approximate current market costs for oil and natural gas are shown in Fig. 3. The coal costs used in this report are also shown. If a plant can be built with utility financing and can burn coal costing less than about $\$ 25$ per ton, then crude liquids produced by these plants should be competitive with the current cost of oil. Note that the synthetic crude liquids produced have a higher heating value and a lower sulfur content than normal crude oil and should command a somewhat higher price.

Combustion of the crude liquid product (all liquid fractions combined) should produce a sulfur dioxide emission of 0.6 to $0.8 \mathrm{lb} / 10^{6}$ Btu, which meets the Environmental Protection Agency's new source performance standards for a liquid fuel in large electric generating plants. The sulfur content of the products and internal fuels is given in Table 4. The total water use is estimated to be 27.7 and $32.5 \mathrm{gal} / 10^{6} \mathrm{Btu}$ of total fuel products for the nuclear and fossil cases respectively. 
Table 3. Cost estimate bases

(July 1974 dollars)

\begin{tabular}{|c|c|c|c|c|}
\hline Item & Low estimate & & High & estimate \\
\hline Coal, $\$$ per $10^{6} \mathrm{Btu}$ & 0.50 & & & 1.75 \\
\hline$\$$ per ton $12,000 \mathrm{Btu} / 1 \mathrm{~b}$ & 12 & & & 42 \\
\hline Nuclear fuel, $\$$ per $20^{6} \mathrm{Btu}$ & 0.25 & & & 0.60 \\
\hline Raw water, \$ per 1000 gal & 0.30 & & & 0.30 \\
\hline Fixed charge rate, $\%$ per year & 15 & & & 25 \\
\hline \multicolumn{5}{|l|}{ Nuclear reactor cost } \\
\hline Capital & & $\$ 800$ million & & \\
\hline Operating & & $\$ 9$ million per year & & \\
\hline Interest during construction & & $8 \%$ per year & & \\
\hline Standard operating year & & 330 days & & \\
\hline Chemical plant lifetime & & 20 years & & \\
\hline \multicolumn{5}{|l|}{ Potential credits } \\
\hline Ammonia $^{a}$ & & $\$ 60$ per ton & & \\
\hline Sulfur ${ }^{\alpha}$ & & $\$ 25$ per ton & & \\
\hline Char (residue, $8235 \mathrm{Btu} / \mathrm{lb}$ ) & & $\$ 3$ per ton & & \\
\hline
\end{tabular}

\footnotetext{
arocess Evaluation Group, U.S. Bureau of Mines, H-Coal Process, Liquid Fuels from Wyodak Coal Twenty-Five Thcusand Barrels Per Day Liquid Fuels Plant, An Economic Analysis, Report 7523, U.S. Bureau of Mines, Morgantown, W. Va., March 1975.
} 


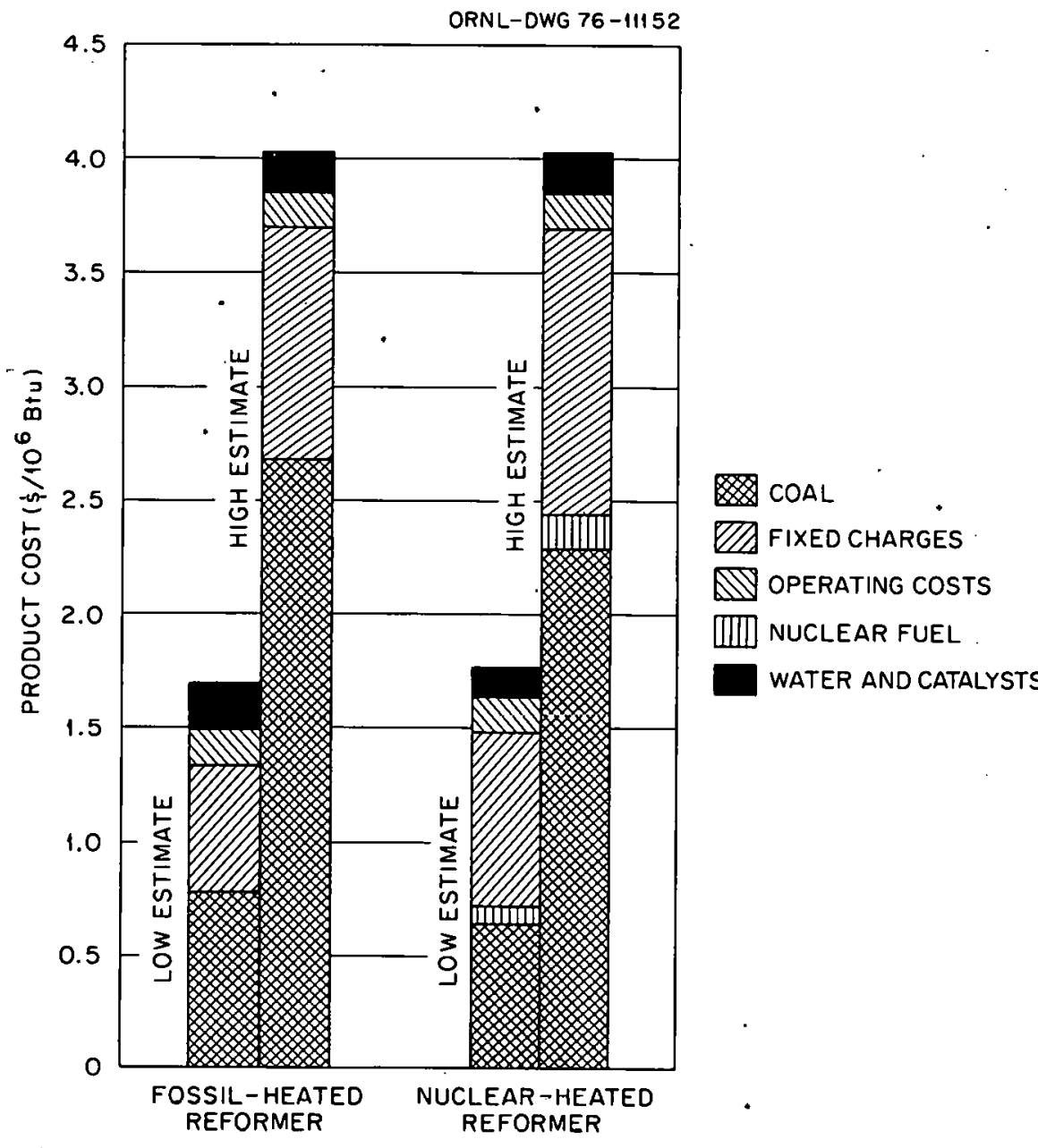

Fig. 2. Product costs.

\subsubsection{Cost estimate bases}

The capital cost of the coal liquefaction plant was estimated using UE\&C coal and chemical processing experience and estimates prepared by others for similar plants. Costs for the process and offsite sections were based on estimates published by Hydrocarbon Research, Inc., American Oil Company, the U.S. Bureau of Mines, and General Atomic Company. Applicable costs of equipment and/or sections were converted to July 1974 doilars using the Chemical Engineering (CE) plant cost index. Because the plant: consists of multiple, identical equipment trains, the cost of the equipment was assumed to be directly proportional to the plant capacity. The escalated and extrapolated costs were then compared and adjusted as required for differences in design. Electricity generating costs are based on recent UE\&C experience. 


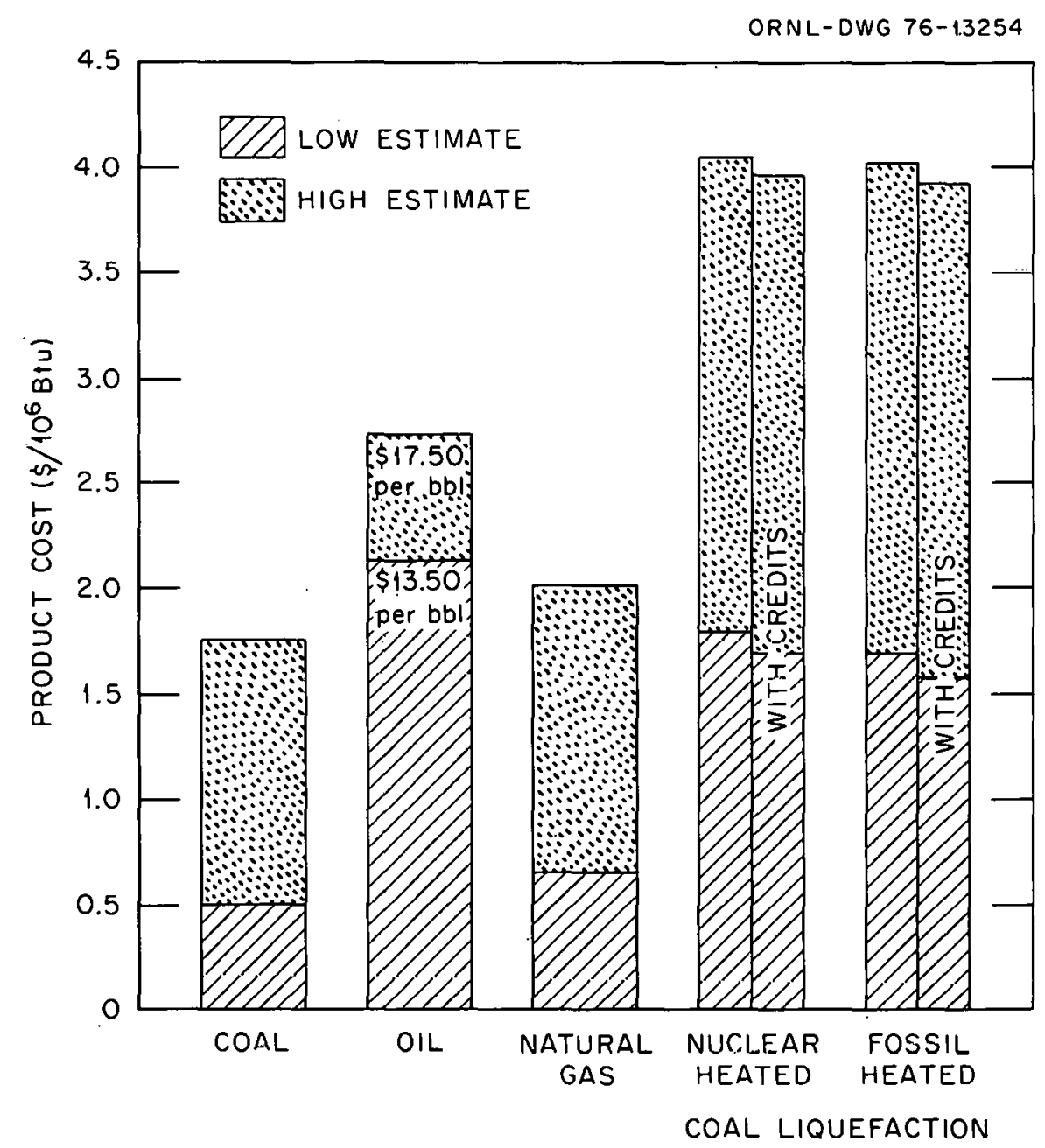

Fig. 3. Comparison of product costs.

The capital costs of the nuclear- and fossil-heated plants are shown in Table 5. The cost of the VHTR system was taken as $\$ 800$ m111ion as a basis for this study.

The costs of catalysts and other chemicals were obtained from the referenced cost estimates and were escalated to July 1974 dollars using the CE industrial chemicals wholesale price index. These costs were adjusted for the size and stream factor of the plant.

Direct operating costs were also obtained from the referenced estimates. Operating and supervisory labor costs were adjusted for plant size, stream factor, the CE chemical products hourly earnings index, and the CE chemical products productivity index. Maintenance was assumed to be $4 \%$ of the capital cost for onsite facilities and $2 \%$ For those offisite. 
Table 4. Sulfur content of products and internal fuels

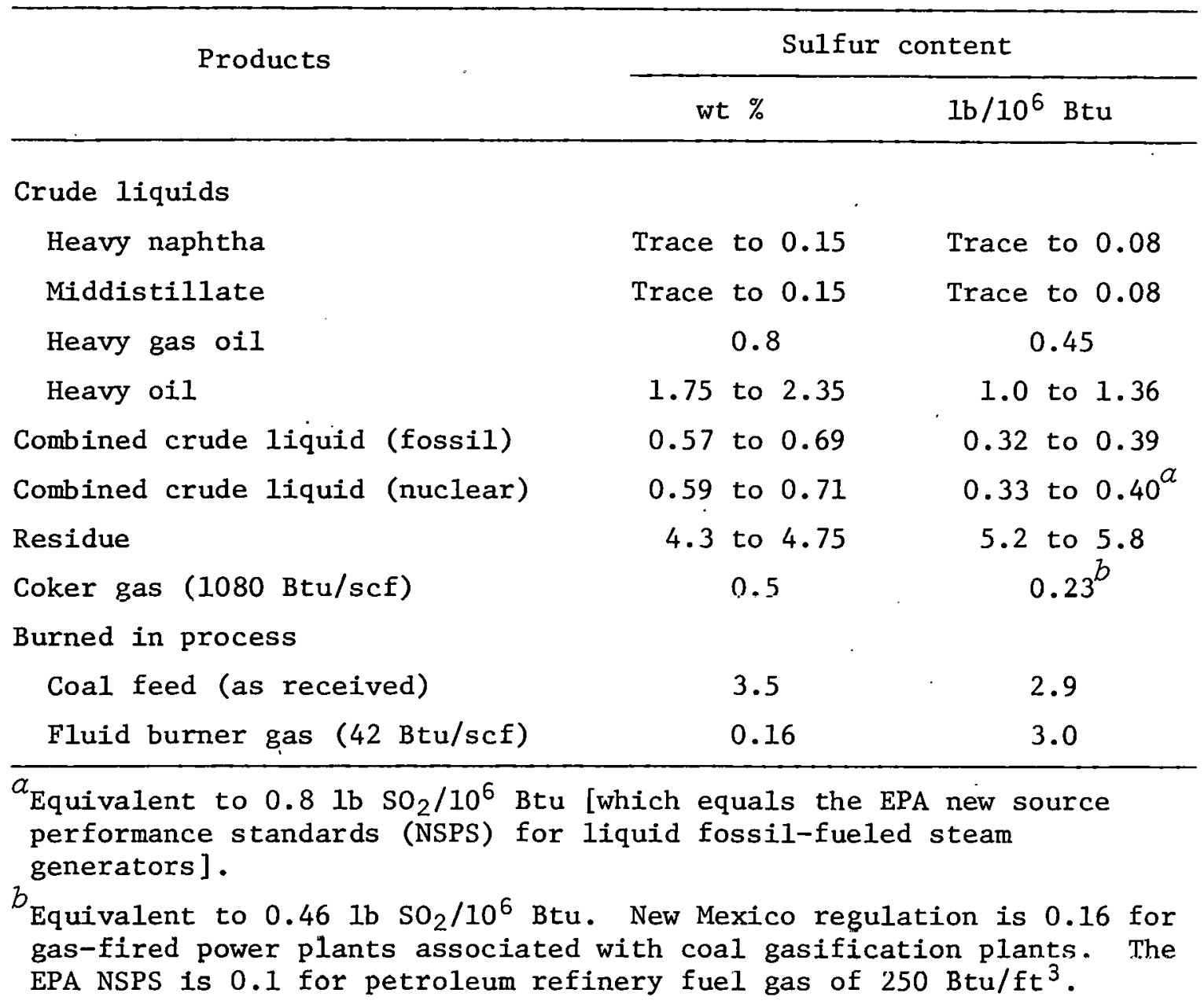

The capital, operating, and fuel costs for these plants were calculated in dollars per million Btu of products and are presented in Table 6. Two cases, high and low, are shown for each plant.

Also shown in Table 6 are credits for ammonia, sulfur, and the residual char. The ammonia and sulfur are useful industrial-quality products if a customer is found for these quantities. The values of the ammonia and sulfur were obtained from the U.S. Bureau of Mines. The char has a heating value of $8235 \mathrm{Btu} / \mathrm{lb}$, but the sulfur and ash contents are fairly high ( 4.3 and $36 \mathrm{wt} \%$ respectively). The credit of $\$ 3$ per ton of char was arbitrarily assumed by UE\&C.

\subsubsection{Conclusions}

United Engineers concluded that the modified $\mathrm{H}$-Coal process, either fossil or nuclear, can produce synthetic crude liquids that are competitive with and maybe cheaper (with utility financing and cheap coal) than imported crude oil. 
Table 5. Capital cost estimate

(July 1974 dollars)

\begin{tabular}{|c|c|c|}
\hline \multirow{2}{*}{ Section } & \multicolumn{2}{|c|}{ Capital cost $\left(\$ \times 10^{6}\right)$} \\
\hline & Fossil & Nuclear \\
\hline 100 - Coal preparation & 80 & 80 \\
\hline 200 - Coal hydrogenation & 320 & 320 \\
\hline 300 - Liquid products/Solvent recovery & & \\
\hline 400 - Fluid coking & 60 & 60 \\
\hline $\begin{array}{l}500 \text { - Reforming and shift conversion } \\
600-\text { Hydrogen production }\end{array}$ & 320 & 235 \\
\hline 700 - Ammonia and sulfur recovery & 9 & 9 \\
\hline $\begin{array}{l}1000,1100,1200,1300 \text { - Miscellaneous } \\
\text { offsite }\end{array}$ & 178 & 178 \\
\hline $\begin{array}{l}1400 \text { - Electricity generation (by char } \\
\text { combustion) }\end{array}$ & 64 & 36 \\
\hline Tankage & 33 & 33 \\
\hline Subtotal & 1064 & 951 \\
\hline $\begin{array}{l}\text { Interest during construction (IDC) - } \\
8 \% \text { for four years }\end{array}$ & 177 & 158 \\
\hline $\begin{array}{l}\text { VHTR system (includes IDC at } 8 \% \text { for } \\
\text { eight years) }\end{array}$ & & 800 \\
\hline Total & 1241 & 1909 \\
\hline
\end{tabular}

The use of nuclear process heat for coal liquefaction by this process results in a more efficient utilization of the energy in the coal. However, there is no other significant advantage to be gained.

\subsubsection{Conceptual design of a coal-steam gasification process heated by a gas-cooled reactor}

\subsubsection{Gelieral}

Conceptually, a gas-cooled reactor can be designed to operate at a high enough gas outlet temperature to permit the use of nuclear heat for the promotion of certain chemical reactions. One such proposal is to use nuclear heat to promote the steam-carbon reaction, producing a synthcsic gae (primarily carbon monoxide and hydrogen) which may be used to synthesize compounds such as methane (for synthetic pipeline gas), 
Table 6. Product cost estimate (July 1974 dollars)

\begin{tabular}{|c|c|c|c|c|}
\hline \multirow[b]{3}{*}{ Item } & \multicolumn{4}{|c|}{ Product cost $\left(\$ / 10^{6} \mathrm{Btu}\right)^{\alpha}$} \\
\hline & \multicolumn{2}{|c|}{ Fossil heat } & \multicolumn{2}{|c|}{ Nuclear heat } \\
\hline & Low $^{b}$ & $\mathrm{High}^{b}$ & Low & High \\
\hline $\begin{array}{l}\text { Coal } \\
\text { Nuclear fuel }\end{array}$ & 0.78 & 2.71 & $\begin{array}{l}0.66 \\
0.06\end{array}$ & $\begin{array}{l}2.31 \\
0.14\end{array}$ \\
\hline $\begin{array}{l}\text { Raw water } \\
\text { Catalysts and chemicals }\end{array}$ & $\begin{array}{l}0.01 \\
0.12\end{array}$ & $\begin{array}{l}0.01 \\
0.12\end{array}$ & $\begin{array}{l}0.01 \\
0.10\end{array}$ & $\begin{array}{l}0.01 \\
0.10\end{array}$ \\
\hline $\begin{array}{l}\text { Direct operating cost } \\
\text { Process plant } \\
\text { Electricity generation } \\
\text { HTGR }\end{array}$ & $\begin{array}{l}0.15 \\
0.03\end{array}$ & $\begin{array}{l}0.15 \\
0.03\end{array}$ & $\begin{array}{l}0.12 \\
0.02 \\
0.03\end{array}$ & $\begin{array}{l}0.12 \\
0.02 \\
0.03\end{array}$ \\
\hline Fixed charges & 0.61 & 1.02 & 0.80 & 1.33 \\
\hline Total product cost & 1.70 to & 4.04 & 1.80 to & 4.06 \\
\hline $\begin{array}{l}\text { Potential credits } \\
\text { Ammonia } \\
\text { Sulfur } \\
\text { Char }\end{array}$ & $\begin{array}{l}0.0 \\
0.03 \\
0.02\end{array}$ & & $\begin{array}{l}0.02 \\
0.03 \\
0.04\end{array}$ & \\
\hline Potential product cost & 1.60 to & 3.94 & 1.71 to & 3.97 \\
\hline
\end{tabular}

ammonia, methanol, or longer chain hydrocarbons, such as gasoline, via the Fischer-Tropsch reaction.

To allow estimation of the feasibility of such a process, a simplified material and heat balance flow sheet for one such scheme has been developed. The flow sheet is based on a VHTR with a gas outlet temperature of $982^{\circ} \mathrm{C}\left(1800^{\circ} \mathrm{F}\right)$ and a thermal rating of $3000 \mathrm{MW}(\mathrm{t}) .9^{9}$

The heat from the nuclear reactor is transferred to the coal processing system by recirculating helium gas. To accomplish this, part of the reactor heat contained in a primary helium recirculating stream is transferred to a secondary helium recirculating stream by an intermediate heat exchanger (IHX). The heat content of the secondary helium stream is then used in the coal processing plant. The heat remaining in the primary helium is used to generate high-pressure steam, part of which supplies power to the helium circulators and to the coal-plant product gas compressor; the remainder generates electricity for in-plant use and for sale. About $62 \%$ of the VHTR thermal output is used in the coal processing plant; the remainder is used to generate electricity. 
The secondary helium stream, heated to $932^{\circ} \mathrm{C}\left(17.10^{\circ} \mathrm{F}\right)$ in the $\operatorname{IHX}$, is routed to the steam-carbon reactor where it is cooled to $850^{\circ} \mathrm{C}$ $\left(1562^{\circ} \mathrm{F}\right)$ by heat exchange with the reacting bed of coal at $800^{\circ} \mathrm{C}$ $\left(1472^{\circ} \mathrm{F}\right)$. The helium flow leaving the steam-carbon reactor is split, with about $16.5 \%$ flowing to the carbonizer and the remainder flowing to the process steam generator. The helium leaves the carbonizer and the steam generator at the same temperature $\left(662^{\circ} \mathrm{C}\right.$ or $\left.1224^{\circ} \mathrm{F}\right)$, is recombined, compressed, and returned to the IHX.

Incorporation of an IHX is dictated by the need for isolation of the coal processing system from the nuclear reactor system to reduce the danger of cross-contamination from leaks that might occur as a result of the high-temperature, corrosive conditions in the coal-conversion plant.

The use of the IHX decreases the plant capacity as a result of the inherent temperature gradients associated with heat exchange equipment. An approach temperature or minimum temperature difference of $50^{\circ} \mathrm{C}\left(90^{\circ} \mathrm{F}\right)$ was assigned to the IHX and to the steam-carbon process heat exchanger (PHX) in the high-temperature section of the secondary helium loop. The sum of these approach temperatures (the temperature drop required to achieve the desired heat transfer) for the intermediate and the steamcarbon reactor heat exchangers is $100^{\circ} \mathrm{C}\left(180^{\circ} \mathrm{F}\right)$. This temperature decrease lowers the quantity of heat available for transfer to the reactor fluid bed and therefore limits the gasifier production rate. Higher or lower fluid-bed temperatures affect the quantity of heat transferred and thus the reactor throughput. Additionally, since the effect of temperature on the reaction rate is marked, changes in bed temperature change the gasifier size (and its capital cost). Lower bed temperatures require larger reactors and vice versa for a constant gasification rate. With a sufficient carbon supply, a higher helium temperature results in a higher heat transfer rate and bed temperature and thus a higher gas generation rate.

The reactor bed temperature is a function of the heat transfer rate and the reaction rate as expressed by

$$
q_{r} k w=U A \Delta T_{1 \mathrm{~m}},
$$

where $q_{r}$ is the heat of reaction, $k$ is the specific reaction rate as a function of temperature, and $w$ is the quantity of carbon available for reaction. 10 This product is equated to the product of $U$, the overall heat transfer coefficient, multiplied by $A$, the heat transfer area, and $\Delta T_{1 \mathrm{~m}}$, the $\log$ mean temperature difference, which is a function of the inlet and outlet helium temperatures and the bed temperature. By fixing values for $w, A$, and $q_{r}$, calculating the overall heat transfer coefficient $U$, and substituting the appropriate value for $k$ (from the Arrhenius equation, $k=k_{o} e^{-E / R T}$ ) as determined by experiments on the coal to be processed, a bed temperature and gas generation rate may be calculated.

For this flow sheet, since specific experimental data were lacking, a nominal reaction temperature of $800^{\circ} \mathrm{C}\left(1472^{\circ} \mathrm{F}\right)$ was assumed, thus fixing the average temperature difference, the heat input rate to the reactor, and, in turn, the coal consumption rate. With these values fixed, the remaining flows were calculated and the heat balance determined. 


\subsubsection{Coal reactivity}

The rate of coal gasification in the steam-carbon reaction is primarily a function of the reaction temperature and the inherent reactivity of the coal. The reactivity of the coal is generally dependent on its rank, ranging from a maximum for lignite to a minimum for anthracite. ${ }^{11}$ For example, as shown in Fig. 4, at $800^{\circ} \mathrm{C}\left(1472^{\circ} \mathrm{F}\right)$ the specific reaction rate for lignite in a laboratory test was about $38 \%$ of the carbon gasified per minute, whereas anthracite, in semicommercial tests, 12 showed a specific carbon conversion rate of only about $0.19 \%$ / min, a difference of 200-fold.

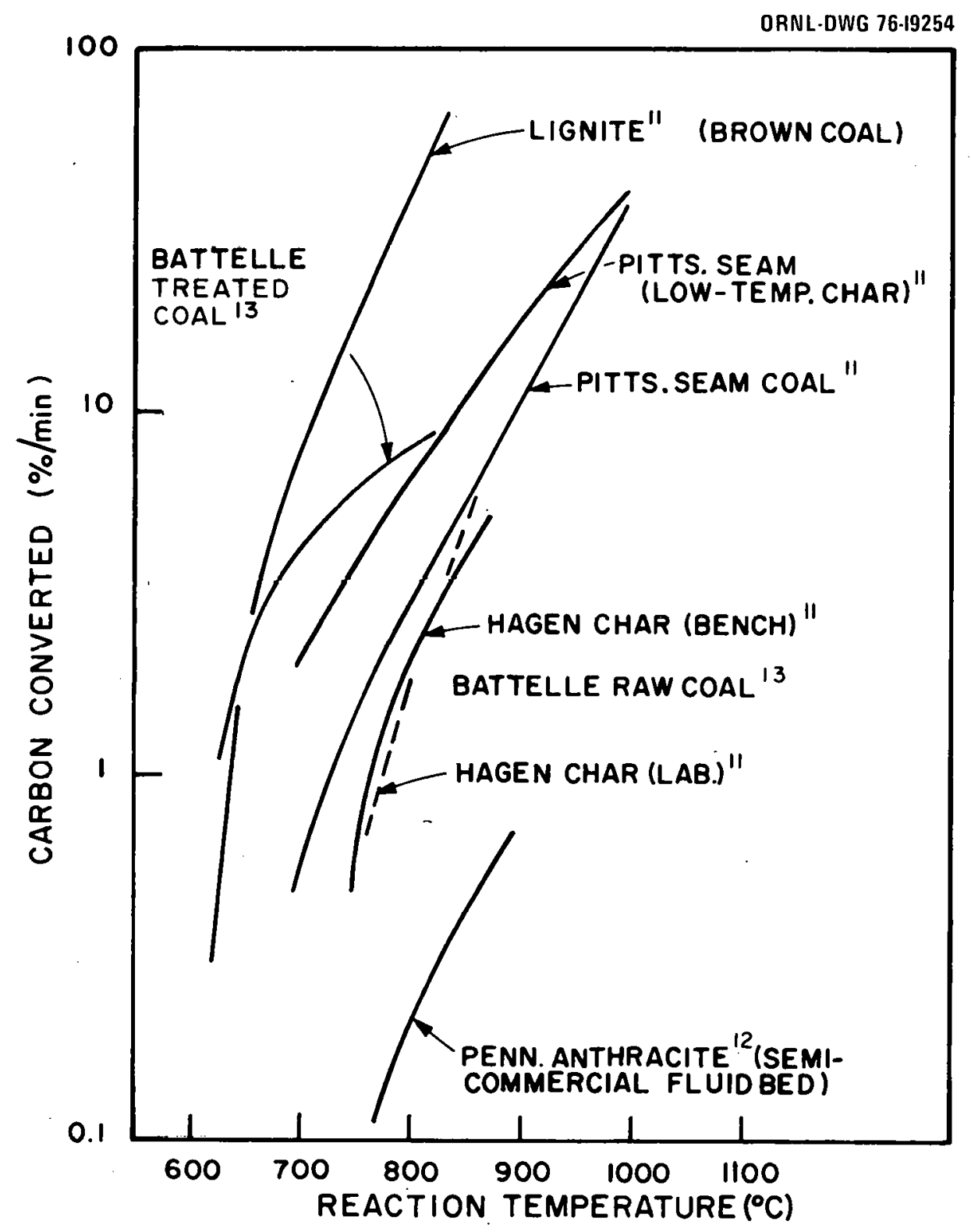

Fig. 4. Steam-carbon reaction rates for various types of coal. 
Higher temperatures greatly increase the reaction rates - as exemplified by the Koppers-Totzek reactor where the gasification of carbon approaches $100 \%$ - and the reaction essentially is accomplished instantaneously at the nominal operating temperature of $1800^{\circ} \mathrm{C}\left(3272^{\circ} \mathrm{F}\right)$. Specific reaction rates, at temperatures up to about $900^{\circ} \mathrm{C}\left(1652^{\circ} \mathrm{F}\right)$, can be enhanced by pretreatment of the feed coal and by the addition of inorganic salts, for example, calcium oxides or carbonates. A case in point is Battelle Treated Coal (BTC), where aqueous treatment with lime and $\mathrm{NaOH}$ (nominally to remove sulfur) results in an increase by a factor of about 5 in the carbon-steam reaction rate compared with that of the untreated coal, using a Pittsburgh seam coal as feed, a reaction temperature of $825^{\circ} \mathrm{C}\left(1517^{\circ} \mathrm{F}\right)$, and a pressure of 500 psig. 13

According to Van Heek, Juentgen, and Peters, ${ }^{11}$ hard coals exhibit a nearly constant reactivity over a range of volatile matter from about $5 \%$ to $30 \%$. Above about $35 \%$-volatile matter, the carbon steam reaction rate starts to increase. Van Heek, Juentgen, and Peters found that the effect of steam pressure, above $10 \mathrm{~atm}$ and up to $70 \mathrm{~atm}$, on reaction rates of coals is small. (However, for lignite, a minimum rate appeared at about 35 atm and a maximum at about 50 atm.) Particle size also had no marked effect below about $2 \mathrm{~mm}(0.08 \mathrm{in.})$. The only effect of an increase in steam pressure on the coal gasification reaction appeared to be an increase in the concentration of methane in the outlet gas, presumably due to an increase in the hydrogasification and methanation reaction rates, which are pressure sensitive.

The use of nuclear heat, with its inherent temperature limitations resulting from the multiple transfers of heat required to transport heat from the nuclear fuel to the gasifier, requires that a relatively reactive coal be used or that the volume of the reacting coal bed in the converter be extremely large. Hence, if nuclear heat is used for the steam-carbon reaction, it will probably be applied to the conversion of the higher volatility coals, lignites, or coals whose reactivity has been enhanced catalytically. For this flow sheet, a Pittsburgh seam coal having a volatile content of $36.0 \%$ was chosen as the feed material.

\subsubsection{Processing plant chemistry}

In the steam-carbon reaction system, the following chemical reactions are important:

1. Coal devolatilization or carbonization - Coal volatile matter $\rightarrow \mathrm{C}+\mathrm{CH}_{4}+$ light oils and tars. The heat requirement for this reaction is estimated to be about $830 \mathrm{cal} / \mathrm{g}$ of coal ( $1500 \mathrm{Btu} / \mathrm{lb})$. For coals of higher volatility, the temperature required to initiate devolatilization is about $300^{\circ} \mathrm{C}\left(572^{\circ} \mathrm{F}\right)$, and devolatilization is essentially complete at about $700^{\circ} \mathrm{C}\left(1292^{\circ} \mathrm{F}\right)$.

2. Carbon-steam reaction $-\mathrm{C}+\mathrm{H}_{2} \mathrm{O} \rightarrow \mathrm{H}_{2}+\mathrm{CO}, \Delta H=32,400$ $\mathrm{cal} / \mathrm{g}-\mathrm{mole}$ ( $58,300 \mathrm{Btu} / \mathrm{lb}-\mathrm{mole})$. Depending on coal reactivity, this reaction will begin at a temperature of 
about $650^{\circ} \mathrm{C}\left(1202^{\circ} \mathrm{F}\right)$ for lignite. 11 The reaction rate increases rapidly with temperature, with the reaction becoming essentially instantaneous at temperatures above about $1100^{\circ} \mathrm{C}\left(2012^{\circ} \mathrm{F}\right)$. Catalytic materials such as lime will accelerate the reaction at lower temperatures with some coals.

3. Carbon monoxide shift reaction - $\mathrm{CO}+\mathrm{H}_{2} \mathrm{O} \rightarrow \mathrm{CO}_{2}+\mathrm{H}_{2}, \Delta H=$ $-9200 \mathrm{cal} / \mathrm{g}$-mole $(-16,600 \mathrm{Btu} / \mathrm{lb}$-mole). With sufficient gas residence time and in the presence of catalytic surfaces such as ash residues in the reacting bed, this reaction will approach thermodynamic equilibrium. $14-16$ The reaction rate is accelerated by higher temperatures.

4. Hydrogasification reaction $-\mathrm{C}+2 \mathrm{H}_{2} \rightarrow \mathrm{CH}_{4}, \Delta H=-21,200$ cal/g-mole $(-38,200 \mathrm{Btu} / \mathrm{lb}-$ mole). This reaction proceeds primarily at lower temperatures (less than $1100^{\circ} \mathrm{C}$ or $2012^{\circ} \mathrm{F}$ ) and at pressures greater than atmospheric. Higher pressures and lower temperatures increase the equilibrium methane concentration.

The compositions shown on the flow sheet for the steam-carbon reaction were calculated by assuming that the percent water decomposition was about $60 \%$, that the shift reaction was at thermodynamic equilibrium, 17 and that the amount of methane formed was small (about 3 mole \%). Higher quantities of methane would be formed if the reaction pressure were increased [the equilibrium concentration being about $8 \%$ to $10 \%$ at 20 atm and $16 \%$ to $18 \%$ at 68 atm and $\left.800^{\circ} \mathrm{C}\left(1472^{\circ} \mathrm{F}\right)\right]$. Thus, if the ultimate product of the reaction were to be synthetic pipeline gas rather than carbon monoxide and hydrogen, it would be advantageous to increase the reaction pressure, maximizing the conversion of carbon to methane in the reactor rather than in an external methanator.

\subsubsection{Flow sheet discussion}

The nuclear-heat-driven steam-carbon process as conceptually depicted in the flow sheet (Fig. 5) results in the plant yields and thermal efficiencies shown in Table 7. The overall thermal efficiency of the system is defined as the ratio of the total heating values of the plant products (including the thermal equivalent of the electricity generated for sale) to the total heating value of the coal feed to the plant plus the heat generated by the VHTR heat source.

Because the flow sheet described for the process was conceptual in nature, the assumption was made that sufficient waste and excess heat were available in the process offgases and the process steam generator to supply heat for the plant auxiliary processes such as coal driers and product gas purifiers. An in-plant electrical requirement of 14 MW(e) was assumed to be available from the 319-MW(e) power plant. The large power consumers, that is, the helium circulators and the product gas compressors, were assumed to be driven directly by high-pressure steam 


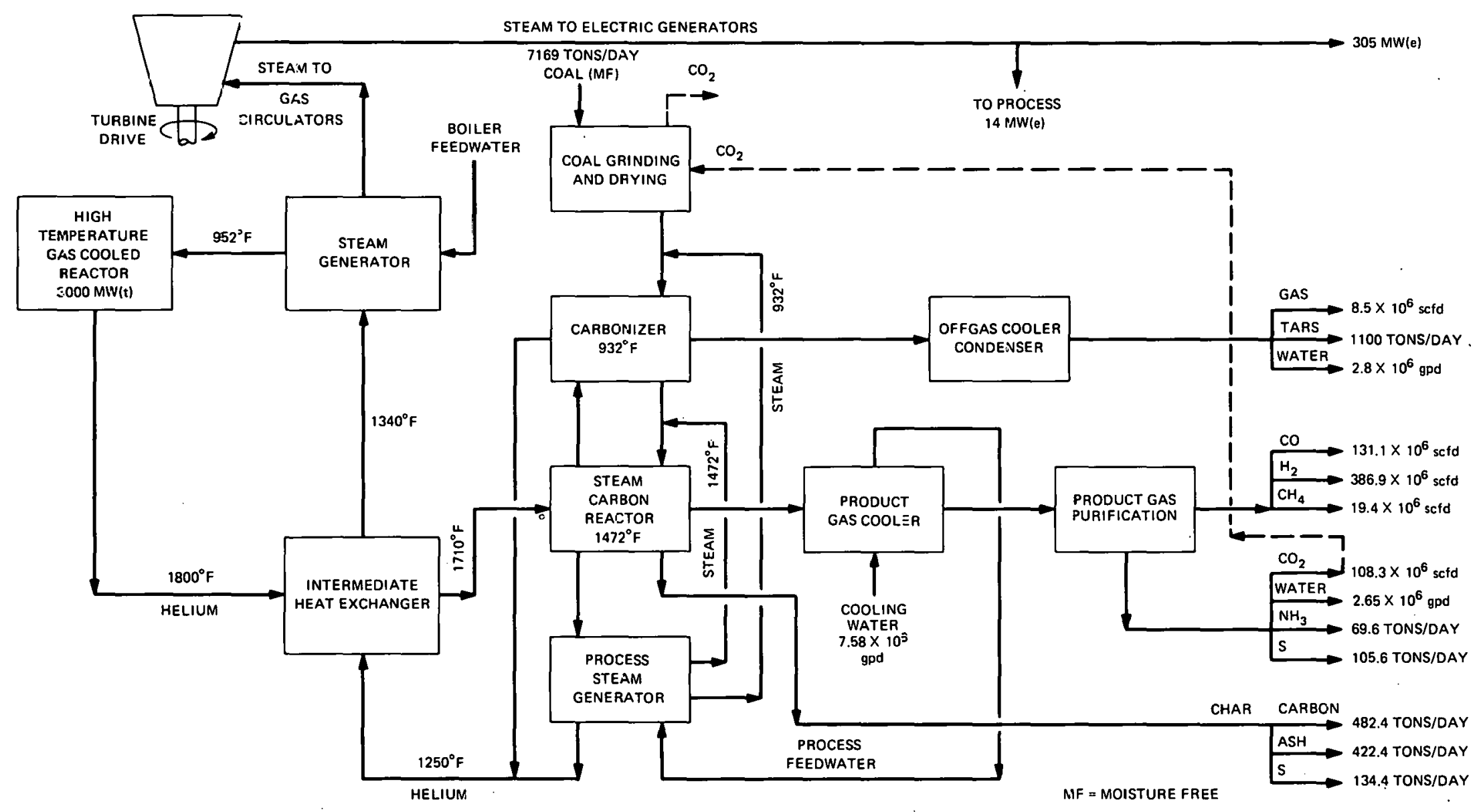

Fig: 5. Steam gasification of coal using nuclear heat. 
Table 7. Plant efficiency summaries

\begin{tabular}{|c|c|c|c|c|c|}
\hline System & \multicolumn{2}{|c|}{ Input (Btu per day) } & \multicolumn{2}{|c|}{ Output (Btu per day) } & $\begin{array}{r}\text { Thermal } \\
\text { efficiency }(\%)\end{array}$ \\
\hline Overal1 & $\begin{array}{l}\text { Coal } \\
\text { VHTR }\end{array}$ & $\begin{array}{l}2.01 \times 10^{11} \\
2.46 \times 10^{11}\end{array}$ & $\begin{array}{l}\text { Coal products } \\
\text { Electric power }\end{array}$ & $\begin{array}{l}2.57 \times 10^{11} \\
0.25 \times 10^{11}\end{array}$ & $63.1^{a}$ \\
\hline Total & & $4.47 \times 10^{11}$ & & $2.82 \times 10^{11}$ & \\
\hline Coal conversion plant & $\begin{array}{l}\text { Coal } \\
\text { VHTR } \\
\text { Electric power }\end{array}$ & $\begin{array}{l}2.01 \times 10^{11} \\
1.59 \times 10^{11} \\
0.01 \times 10^{11}\end{array}$ & $\begin{array}{l}\text { Product gas } \\
\text { Coal gas }{ }^{e} \\
\text { Tar and light oil }\end{array}$ & $\begin{array}{l}1.96 \times 10^{11} \\
0.21 \times 10^{11} \\
0.40 \times 10^{11}\end{array}$ & $71.2^{a, b}$ \\
\hline Total & & $3.61 \times 10^{11}$ & & $2.57 \times 10^{11}$ & \\
\hline Power plant & & $0.87 \times 10^{11} d$ & & $0.25 \times 10^{11}$ & 28.7 \\
\hline
\end{tabular}

$a_{\text {Not including char heating value. }}$

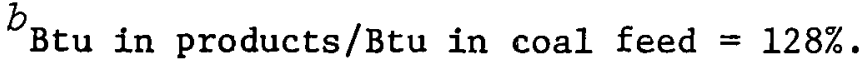

$c_{\text {Light volatiles from carbonizer. }}$

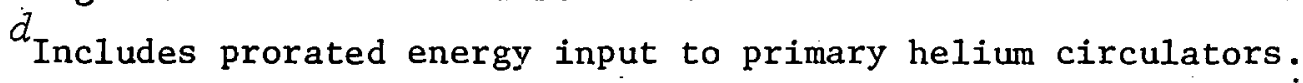


from the VHTR steam generator. On this basis, the overall plant thermal efficiency was found to be $63.1 \%$. If the generation of electricity and the corresponding VHTR heat input are excluded from the energy balance, the overall thermal efficiency of the coal plant is $71.2 \%$.

\subsubsection{Materials of construction}

The outlet temperature of the VHTR was assumed to be $982^{\circ} \mathrm{C}\left(1800^{\circ} \mathrm{F}\right)$, which is about $222^{\circ} \mathrm{C}\left(400^{\circ} \mathrm{F}\right)$ higher than current HTGR designs. Hightemperature alloys such as Incoloy $800 \mathrm{H}$ are therefore extensively required in the high-temperature areas of the plant such as the IHX, where the maximum operating temperature is $982^{\circ} \mathrm{C}\left(1800^{\circ} \mathrm{F}\right)$, and the carbonizer and steam-carbon reactor PHX, which contain helium at $850^{\circ} \mathrm{C}\left(1562^{\circ} \mathrm{F}\right)$ and $932^{\circ} \mathrm{C}\left(1710^{\circ} \mathrm{F}\right)$ respectively. In addition to the high internal temperature, the PHXs are subject to the erosive action and stresses associated with a large, turbulent, fluidized coal bed, as well as the effects of the corrosive environment of the gasifier.

The reactor shells of both the carbonizer and the steam-carbon reactor are constructed of carbon steel clad on the inside with a corrosion-resistant layer of stainless steel. To protect the reactor vessel wall from the high reaction temperatures, it is lined with an insulating refractory material such as Kaolin.

Periodic replacement of the high-temperature heat exchange surfaces and of the refractory vessel lining will undoubtedly be required. The frequency of such replacements cannot, at this time, be estimated with any degree of accuracy. However, for conceptual cost estimation purposes, the lifetime of these components was taken to be five years.

The PHX materials problem is anticipated to be the most severe. Standard materials of construction used in conventional chemical plants handling similar compounds and in coal-fired steam plants may be used for most other components.

\subsubsection{Pollution}

No significant pollution problems should be encountered in the coal-conversion plant because the design incorporates adequate abatement equipment in the processing steps. Solid wastes, primarily char, will be returned to the mine or trucked to a suitable site for burial. Aqueous wastes will be treated to remove oils and tars, then used as makeup to the recirculating cooling water system, where most of the remaining organics will be decomposed by oxidation. The cooling tower blowdown will be combined with the sanitary sewage and will be subjected to complete secondary treatment prior to discharge to adjacent surface waters. Waste gases will be scrubbed prior to discharge to the atmosphere to remove noxious compounds. The scrub water will be treated to remove these compounds prior to combination with other plant wastewater. Any sulfur compounds and ammonia removed during this treatment will be combined with other similar plant streams and recovered. Minor amounts of anmonia and coal-derived organics, in quantities too small to be economically reclaimable, will be disposed of by incineration. 


\subsubsection{Process flow description}

\subsection{Nuclear heat source}

The VHTR is the source of all heat used in the coal-conversion process. The heat from the nuclear reactor is transferred to the process by recirculating helium gas in two separate loops, the primary loop and the secondary loop. In operation, heat is extracted from the nuclear reactor core by the primary loop helium and transferred in the IHX to the helium in the secondary gas loop and then to the steam generator where it is used to produce high-pressure steam. The high-pressure steam is used to drive the primary and secondary helium circulators and the gas compressors for the coal-conversion-plant product gas and to generate electrical power (about $4 \%$ of which is used in the coal plant and the remainder of which is sold).

The heat transferred to the secondary helium stream is used to supply the heat required for the carbonization and the steam-carbon reactions and to generate the process steam needed for fluidization of the coal in the carbonizer and the steam-carbon reactor.

\subsection{Coal preparation}

Cleaned coal from the mine is retrieved from storage, ground and sized to $100 \%-10 \mathrm{mesh}$, and fed into the fluid-bed coal drier, using carbon dioxide from the gas scrubber system as the fluidizing gas. The carbon dioxide is heated by low-pressure steam obtained from the carbonizer offgas condenser. Essentially all the free moisture in the coal is assumed to be removed in the drying step. The feed coal analysis is shown in Table 8 .

Dust collectors will be installed at all coal and char transfer points, as well as in the coal grinding and pulverizing system. The coal dust will be collected at a central point, briquetted, ground, sized, and combined with the primary coal flow for use in the plant.

\subsection{Carbonizer}

Dried, pulverized coal is fed from the coal drier into a highvelocity section of the fluid-bed carbonization reactor. Here the coal is rapidly heated by contact with hot carbonized coal and with the superheated fluidizing steam to the devolatilization temperature of $500^{\circ} \mathrm{C}\left(932^{\circ} \mathrm{F}\right)$. The high-velocity fluid-bed section discharges in to a low-velocity section, which provides sufficient residence time for about $60 \%$ of the volatile matter in the coal to vaporize. Heat is supplied to the carbonizer by a portion of the secondary helium stream (about $16.5 \%$ of the flow) after it leaves the steam-carbon reactor.

Fluidizing steam and the contained volatiles pass through cyclones to remove particulates, then pass to a heat-recovery condenser where the steam, light oils, and tars are condensed and separated from the 
Table 8. Dried feed coal analyses

\begin{tabular}{|c|c|}
\hline Item & Wt $\%$ \\
\hline \multicolumn{2}{|l|}{ Proximate analysis } \\
\hline Volatile matter & 36.0 \\
\hline Fixed carbon & 57.3 \\
\hline $\mathrm{H}_{2} \mathrm{O}$ & 0.8 \\
\hline Ash & 5.9 \\
\hline Ultimate analysis (moisture and & ash-free basis) \\
\hline Carbon & 84.4 \\
\hline Hydrogen & 5.6 \\
\hline Oxygen & 5.0 \\
\hline Nitrogen & 1.0 \\
\hline Sulfur & 4.0 \\
\hline Higher heating value (Btu/1b) & 14,000 \\
\hline
\end{tabular}

noncondensable hydrocarbon gases. Light oils and tars are recovered from the condensate and are stored and sold with the noncondensable hydrucarbuns.

Heat removed from the vapor condenser is used to generate lowpressure steam to supply heat to various process auxiliaries.

\section{$1 \cdot 2 \cdot 3 \cdot 7.4$ Steam-carbon reactor}

Carbonized coal from the carbonizer is fed to the steam-carbon reactor (a fluid-bed reactor using steam as the fluidizing gas). In this reactor, the steam-carbon and carbon monoxide shift reactions occur, gasifying about $90 \%$ of the carbon in the coal, resulting in a raw product gas consisting primarily of hydrogen, carbon monoxide, carbon dioxide, and excess steam. Residual volatiles in the coal are volatilized and reformed in the reactor to hydrogen and carbon monoxide. Heat is supplied to the reactor by the secondary helium flow through the PHX, an array of metal tubes immersed in the fluid bed. The rapidity of the reaction is governed by the coal reactivity and the temperature of the bed. The attainable rate of heat transfer to the bed and the temperature of the circulating helium are the factors determining the minimum gasifier volume. 


\subsection{Raw gas purification system}

The raw product gas from the steam-carbon reactor passes through a staged cyclone gas-solid separator into the gas cooler. The $800^{\circ} \mathrm{C}$ $\left(1472^{\circ} \mathrm{F}\right)$ gas is cooled to about $349^{\circ} \mathrm{C}\left(660^{\circ} \mathrm{F}\right)$, exchanging its heat with the feedwater stream to the process steam generator. The raw product gas is then quenched and particulates removed in a water scrub tower, compressed to 1000 psia, and sent to an absorption gas purification (Purisol) unit. Here, the sour gas constituents, primarily carbon dioxide and hydrogen sulfide, will be removed by physical absorficion in an organic solvent ( $N$-methyl-pyrrolidone). The carbon dioxide and hydrogen sulfide are separated by the absorption process; the carbon dioxide is returned to the head end of the plant for use in the coal drying and grinding steps and as an inert gas blanket in the coal storage silos and feed hoppers, after which it is vented to the atmosphere. The hydrogen sulfide is sent to a Claus unit and then to a Claus tail-gas treatment unit to convert the hydrogen sulfide to potentially salable elemental sulfur.

\subsection{Process steam generator}

Process steam is required both as a reactant and as a fluidizing gas in the steam-carbon reactor and as a fluidizing gas in the carbonizer. All the required process steam is generated in the process steam generator by heat interchange with a portion of the secondary helium stream (approximately $83.5 \%$ of the flow) after it leaves the steamcarbon reactor. Process steam is generated at about 10-atm pressure and superheated to $500^{\circ} \mathrm{C}\left(932^{\circ} \mathrm{F}\right)$ or $800^{\circ} \mathrm{C}\left(1472^{\circ} \mathrm{F}\right)$ for use in the carbonizer and the steam-carbon reactor respectively.

\subsection{Electrical generation}

Heat in excess of that usable in the steam-carbon reactor is used to generate electric power which, except for the approximately $4 \%$ used in the coal plant, is available for sale. The conversion efficiency of thermal energy to electrical energy was taken as $32 \%$. However, part of the available energy in the steam was assumed to be used to drive the primary helium circulators. This energy use was prorated between the coal plant and the electrical plant, resulting in a net thermal energy conversion efficiency of $28.7 \%$ for the electrical power plant.

\subsection{Cooling water}

The cooling requirements for the plant are met by a recirculating water cooling system equipped with a conventional evaporative type, forced-draft cooling tower. Cooling water will be supplied at $90^{\circ} \mathrm{F}$ and returned at $130^{\circ} \mathrm{F}$. The circulation rate is approximately $131,000 \mathrm{gpm}$. The water makeup rate is estimated to be $5280 \mathrm{gpm}$. 


\subsubsection{Cost estimate}

\subsection{Capital cost}

The capital cost of the coal processing portion of the plant complex was derived by listing the major equipment items and their sizes based on the heat and material balance flow sheet. Costs of these equipment items were then estimated along with the labor required for installation. From this tabulation, a total installed equipment cost was derived, which was then translated to a plant capital cost. To this was added interest during construction, to give a total plant investment which was converted to July 1974 dollars. The capital cost of the VHTR system, which includes the nuclear reactor, helium circulators, and IHX, was taken as $\$ 781.5$ million, including interest during construction ( $8 \%$ for eight years). ${ }^{8}$ The capital cost for the nuclear-coal plant complex is shown in Table 9 .

Table 9. Capital cost estimate (July 1974 dollars)

\begin{tabular}{lc}
\hline \multicolumn{1}{c}{ Cost item } & Capital cost $\left(\$ 10^{6}\right)$ \\
\hline Coal processing plant & 288 \\
Interest during construction (IDC) \\
$(8 \%$ for four years)
\end{tabular}

\subsection{Product cost}

The contributions to the product mix on the basis of Btu content from the steam-carbon plant are given in Table 10. For this estimate, each major price variable was treated parametrically over a range. The resulting costs (Table 11) were then normalized by dividing by the total thermal value of the plant product to give a unit cost per million Btu of product. All plant products were assumed to be of equal value, based on their heats of combustion.

Major cost variables included coal, assumed to vary from $\$ 0.50$ to $\$ 1.75$ per million Btu; nuclear fuel, from $\$ 0.25$ to $\$ 0.60$ per million $\mathrm{Btu}$; the fixed charge rate, $15 \%$ and $25 \%$ per year; and the credit assumed for the sale of excess electric power, 13 and $18 \mathrm{mills} / \mathrm{kWhr}$ (Table 12).

One of the major cost items is the cost of maintaining the internals in the carbonizer and the steam-carbon reactor. The heat exchanger tubes in these units operate at high internal temperatures 
Table 10. Plant product summary

\begin{tabular}{|c|c|c|}
\hline Product & Tons per day & Btu per day \\
\hline \multicolumn{3}{|l|}{ Carbonizer } \\
\hline Light oil + tar & $1.10 \times 10^{3}$ & $0.40 \times 10^{11}$ \\
\hline Gas $\left(C_{1} \rightarrow C_{4}\right)$ & $0.45 \times 10^{3}$ & $0.21 \times 10^{11}$ \\
\hline Total & & $0.61 \times 10^{11}$ \\
\hline \multicolumn{3}{|c|}{ Steam-carbon reactor } \\
\hline Gases & & \\
\hline $\mathrm{H}_{2}$ & $1.08 \times 10^{3}$ & $1.31 \times 10^{11}$ \\
\hline $\mathrm{CO}$ & $5.11 \times 10^{3}$ & $0.44 \times 10^{11}$ \\
\hline $\mathrm{CH}_{4}$ & $0.43 \times 10^{3}$ & $0.21 \times 10^{11}$ \\
\hline Total & & $1.96 \times 10^{11}$ \\
\hline \multicolumn{3}{|l|}{ Solids } \\
\hline Char & $1.04 \times 10^{3}$ & $0.14 \times 10^{11^{a}}$ \\
\hline Electric power & & $0.25 \times 10^{11}$ \\
\hline
\end{tabular}

$\left(850^{\circ}\right.$ to $940^{\circ} \mathrm{C}$ or $1562^{\circ}$ to $1724^{\circ} \mathrm{F}$ ), and their outside surfaces are exposed to a corrosive-erosive atmosphere. No relevant data on the life expectancy of the material of construction (Incology $800 \mathrm{H}$ ) were available; hence, it was arbitrarily assumed that the heat exchange tubing would require replacement every five years. The cost assigned to the plant product for maintenance of these units reflects the high material and labor costs involved in replacing the tubing.

The operating cost assigned to the VHTR is $\$ 9$ million per year, 18 and the operating cost for the coal plant was derived, based on plant capital cost, from a value assoclated with a reactor-heated $\mathrm{H}$-Coal liquefaction plant. ${ }^{19}$ The cost of operating the electrical generators was assumed to be included in the VHTR operating cost.

\subsubsection{Hydrogen from water splitting - electrolytic and thermochemical - and its application to fuel synthesis}

Essentially all the hydrogen produced today is derived from hydrocarbons (methane and naphtha). Hydrogen made by the electrolysis of water is quite expensive and is reserved for uses requiring very high 
Table 11. Product cost estimate of VHTR-heated steam-carbon process (July 1974 dollars)

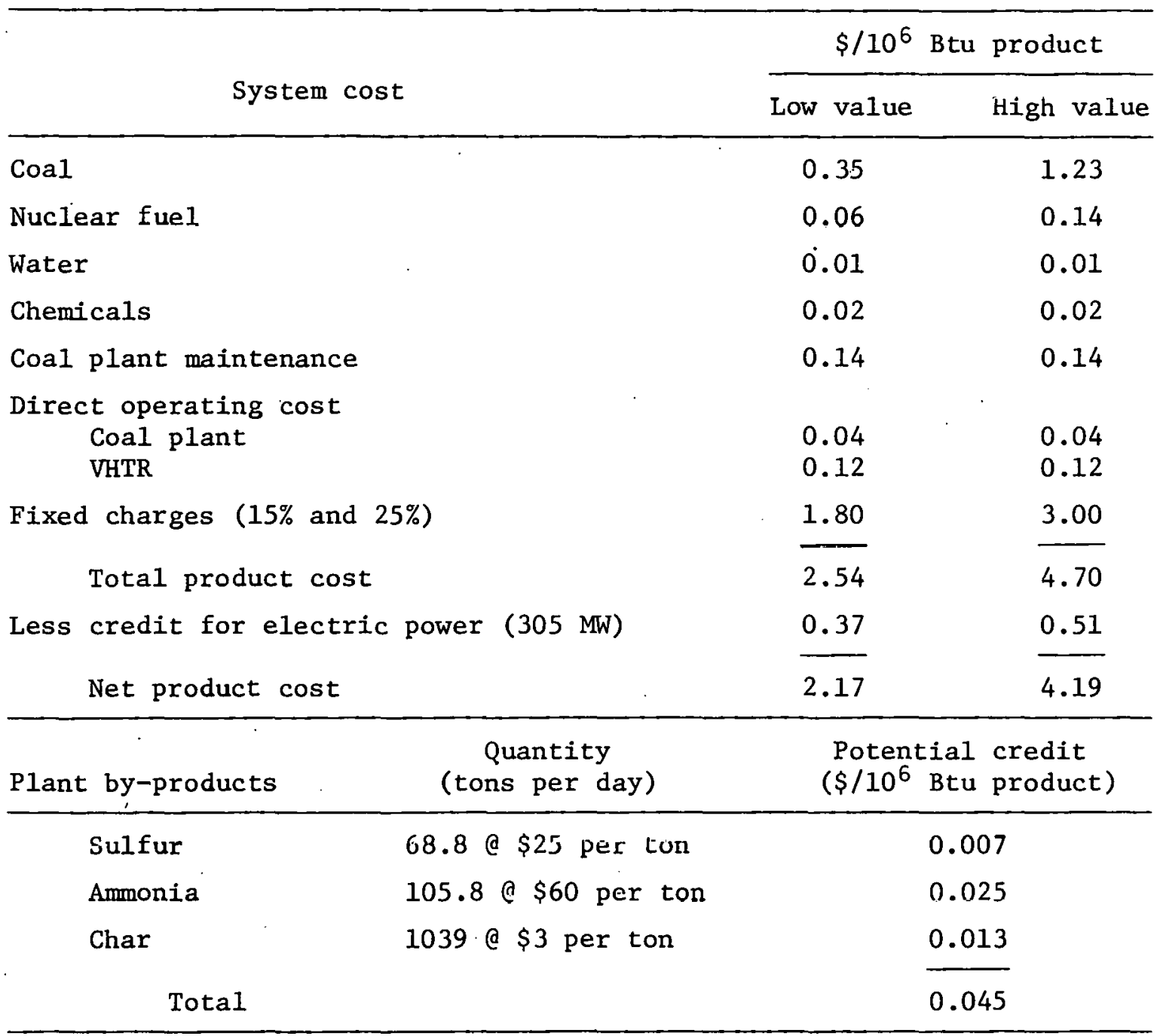

purity. No commercial hydrogen has yet been made by thermochemical water splitting.

In the future, alternative means of hydrogen production will be required because of the increased demand for hydrogen and the limited supply of hydrocarbon feedstock. Table 13 presents four estimates derived by the National Aeronautics and Space Administration (NASA) and its contractors for U.S. hydrogen demand by the year 2000.7,20-22 The most conservative of these estimates projects a fivefold increase in hydrogen requirement. Essentially all the additional hydrogen will be made from natural gas, naphtha, and coal. For the near term, our estimates show hydrogen derived from thermochemical or electrolytic processes to be at least a factor of 2 more expensive than hydrogen derived from coal. 
Table 12. Product cost estimate bases (July 1974 dollars)

\begin{tabular}{lcc}
\hline \multicolumn{1}{c}{ Cost item } & Low estimate & High estimate \\
\hline Coal, $\$ 10^{6}$ Btu & 0.50 & 1.75 \\
Nuclear fuel, $\$ 10^{6}$ Btu & 0.25 & 0.60 \\
Water, \$/1000 gal & 0.30 & 0.30 \\
Fixed charge rate, \% per year & 15 & 25 \\
Nuclear reactor cost & & \\
$\quad$ Capital $-\$ 781.5 \times 10^{6}$ & & 0.018 \\
$\quad$ Operating $-\$ 9 \times 10^{6}$ per year & & \\
$\begin{array}{l}\text { Credit for excess electric power, } \\
\text { \$/kWhr }\end{array}$ & 0.013 & \\
Standard operating year - 330 days & & \\
\hline
\end{tabular}

However, one can clearly see by taking the long view that hydrogen production directly from water via electrolytic or thermochemical processes will ultimately become important.

\subsubsection{Thermochemical processes}

A very large number of chemical cycles are known to be possible, and many have been analyzed and evaluated in U.S. and foreign programs. The Institute of Gas Technology (IGT) ${ }^{22}$ and Bowman ${ }^{23}$ have published discussions of thermochemical cycles.

Within the VHTR program, attention has been focused on the Westinghouse hydrogen production process, which is a hybrid thermochemical-electrolytic cycle being developed by Westinghouse Astronuclear Laboratory. 21 The reaction steps are as follows:

Solution

Anode

Cathode

Thermal decomposition

Net reaction

$$
\mathrm{SO}_{2}+\mathrm{H}_{2} \mathrm{O} \rightarrow \mathrm{H}_{2} \mathrm{SO}_{3}
$$$$
\mathrm{H}_{2} \mathrm{SO}_{3}+\mathrm{H}_{2} \mathrm{O} \rightarrow 2 \mathrm{e}^{-}+\mathrm{H}_{2} \mathrm{SO}_{4}+2 \mathrm{H}^{+}
$$$$
2 \mathrm{H}^{+}+2 \mathrm{e} \rightarrow \mathrm{H}_{2}
$$$$
\mathrm{H}_{2} \mathrm{SO}_{4} \rightarrow \mathrm{SO}_{2}+\mathrm{H}_{2} \mathrm{O}+1 / 2 \mathrm{O}_{2}
$$$$
\mathrm{H}_{2} \mathrm{O} \rightarrow \mathrm{H}_{2}+1 / 2 \mathrm{O}_{2} \text {. }
$$

Westinghouse has confirmed the various steps in laboratory tests. In their assessment of Westinghouse's thermochemical cycle for hydrogen production, Bamberger and Braunstein of ORNL concluded that, from a chemical viewpoint, the process appears feasible and attractive. 24 
Table 13. Es:imates of $U_{\text {is. }}$. hydrogen requirements (in $10^{\text {i5 }}$ Btu)

\begin{tabular}{|c|c|c|c|c|c|c|c|c|c|c|c|}
\hline \multirow{3}{*}{ Item } & & & & \multicolumn{8}{|c|}{2000} \\
\hline & \multicolumn{3}{|c|}{$1972-1973$} & \multirow{2}{*}{$\begin{array}{l}\text { H } \Xi S T \\
\text { reference }\end{array}$} & \multirow{2}{*}{$\begin{array}{l}\text { HEST } \\
\text { maximum }\end{array}$} & \multirow{2}{*}{ GA } & \multicolumn{3}{|c|}{$w^{d}$} & \multicolumn{2}{|c|}{ IGT } \\
\hline & $\mathrm{IGT}^{a}$ & HEST $^{3}$ & $\mathrm{GA}^{c}$ & & & & Low & Base & H1gh & Low & $\mathrm{H} 1 \mathrm{gh}$ \\
\hline Residential/comercial & & & & & & & & & & 5.1 & 14.4 \\
\hline $\begin{array}{l}\text { Ammonia, me thanol, and } \\
\text { miscellaneous chem } 1 c \varepsilon 1 \mathrm{~s}\end{array}$ & 0.42 & 0.46 & 0.60 & 2.37 & 9.25 & 2.81 & 0.76 & 1.47 & 2.14 & 1.5 & \\
\hline Petroleum refining " & 0.42 & 0.47 & 0.48 & 0.78 & 0.78 & 0.60 & 0.58 & 2.41 & 2.41 & 0.9 & \\
\hline Synthetic fuels & & & & 1.71 & 7.6 & 6.99 & 5.82 & 10.32 & 13.33 & 7.1 & 29.1 \\
\hline Steelmaking & & & & 0.22 & 0.65 & 2.11 & 0.09 & 0.18 & 0.36 & 0.7 & \\
\hline $\begin{array}{l}\text { Transportation, utilits, } \\
\text { other }\end{array}$ & 0.05 & 0.07 & 0.06 & 0.40 & 4.21 & 0.37 & & 0.39 & 1.14 & 2.4 & \\
\hline Total & 0.89 & 1.00 & 1.14 & 5.48 & 22.49 & 12.88 & 7.25 & 14.77 & 19.38 & 17.7 & 43.5 \\
\hline
\end{tabular}

$a_{\text {Insticute of Gas Techrology. }}$

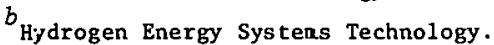

$c_{\text {General Atomic Company. }}$

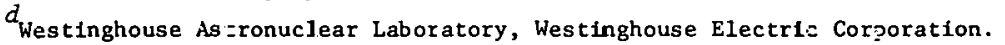


Its advantages include chemical simplicity; use of abundant, low-cost reagents; and no requirement for solids handling. Problems identified included development of suitable separators for the anolyte and catholyte solutions; substitution of electrode materials more suitable than platinized platinum; demonstration of practical construction materials compatible with hot concentrated $\mathrm{H}_{2} \mathrm{SO}_{4}$; and possible effects of corrosion products transported through the system on other parts of the cycle, especially the electrolytic step.

The cycle is projected to achieve a $45 \%$ to $47 \%$ thermal efficiency, which is the highest suggested for any such cycle to date. The Westinghouse estimate of hydrogen production cost is $\$ 4.45$ per $10^{6} \mathrm{Btu}$. However, this estimate assumes nuclear plant capital costs ( $\$ 447 \times 10^{6}$ ) and fuel cycle costs ( $\$ 0.26$ per $10^{6} \mathrm{Btu}$ ) substantially lower than those derived for the VHTR by ORNL. A similar analysis of the Westinghouse water decomposition process by UE\&C for ORNL resulted in hydrogen costs of $\$ 5.17$ to $\$ 8.80$ per $10^{6} \mathrm{Btu}$. The range of costs reflects a nuclear plant capital cost of $\$ 725 \times 10^{6}$ with $15 \%$ and $25 \%$ fixed charge rates and $\$ 0.25$ to $\$ 0.60$ per $10^{6}$ Btu nuclear fuel cycle cost.

\subsubsection{Electrolysis}

As previously stated, the production of hydrogen directly from water will ultimately become important. A great deal of emphasis has been placed on analysis and development of thermochemical processes for water splitting. The competition for thermochemical water splitting is electrolysis. It is of interest to consider how the same advanced nuclear concept (VHTR) used in the analysis of thermochemical cycles would affect electrolytic hydrogen production, if it were applied to generate electricity in a direct coupled mode.

Such a study was conducted by IGT for NASA. ${ }^{25}$ The study is based on a fully dedicated, nuclear-based hydrogen production facility. The advanced-facility concept includes:

1. Advanced-cycle VHTR with $1800^{\circ} \mathrm{F}$ core outlet temperature ( $50 \%$ conversion efficiency).

2. Acyclic de generators ( $99.5 \%$ transmission and contro1 efficiency).

3. High-pressure, high-current-density electrolyzers based on solid polymer electrolyte technology ( $86.3 \%$ conversion efficiency to hydrogen at a pipeline pressure of 1000 psia).

4. Overall efficiency $=43 \%$.

The base case hydrogen product cost presented by IGT is $\$ 5.07$ per $10^{6} \mathrm{Btu}$. Using ORNL-developed VHTR costs, the hydrogen product cost is essentially the same as that projected by UE\&C for the Westinghouse thermochemical process. 
It is clear that the high-temperature reactors that are necessary for thermochemical processes can also contribute high efficiencies when combined with electrolysis technology. Although the theoretical efficiency of some thermochemical cycles is significantly higher than that of the electrolytic process, the thermochemical processes are very complex, and actually achievable efficiencies may not be superior.

Except for hydrogen production from natural gas or oil at current prices, onsite generation from coal is the cheapest method available. In the future, when carbon may become very expensive, it is conceivable that hydrogen from water may become competitive. This possibility was examined during the course of this study.

Assuming the existence of a thermochemical hydrogen plant driven by a 3000-MW( $t$ ) VHTR at an efficiency of $47 \%$ (ref. 3) (hydrogen energy out/VHTR energy in), the flows in a plant producing methanol from coal were calculated. The methanol case was selected because it results in the largest yield increase. As depicted schematically in Fig. 6, the consumption of 8385 tons per day of $\mathrm{H}_{2} \mathrm{O}$ (1398 gpm) would generate 932 tons per day of hydrogen (354 x $\left.10^{6} \mathrm{scfd}\right)$ and 7453 tons per day of oxygen. Using all the hydrogen in a Koppers-Totzek/ICI (Imperial Chemical Industries) methanol production system, 7700 tons per day of methanol would be produced from 5233 tons per day of eastern coal with the following as-received composition:

$$
\begin{array}{ll}
69.9 \% \mathrm{C} & 1.1 \% \mathrm{~S} \\
4.9 \% \mathrm{H} & 13.7 \% \text { ash } \\
7.0 \% \mathrm{O} & 2.0 \% \mathrm{H}_{2} \mathrm{O} \\
1.4 \% \mathrm{~N} & \text { Higher heating value of } 12,700 \mathrm{Btu} / 1 \mathrm{~b}
\end{array}
$$

The oxygen required by the gasifier would be only about $55 \%$ of that available, with the excess (export) oxygen amounting to 3392 tons per day. About $69 \%$ of the gasifier steam requirement of 1758 tons per day could be obtained from the gasifier cooling jacket, and about 7900 tons per day of high-pressure steam would be generated in the waste-heat boiler above the gasifier. Six low-pressure four-head Koppers-Totzek gasifiers would be required. Introduction of the hydrogen into the cleaned synthesis-gas stream changes the molar ratio of hydrogen to $\left(\mathrm{CO}+1.5 \mathrm{CO}_{2}\right)$ from 0.58 upstream of injection to about 2.14 downstream, a value within the usual operating range of 2.0 to $2.4 .26,27$ The slight hydrogen excess is provided to accommodate side reactions and purge gas losses. The net effect would be to halve the coal requirement per unit of production (i.e., to double the yield to $10.5 \mathrm{bbl}$ methanol per ton of coal) and to eliminate the need for an air separation plant and shift converter. The overall energy conversion efficiency, however, would be about $40 \%$, or 10 to 20 percentage points lower than that expected for a plant using coal-derived synthesis gas (especially if second-generation pressurized Koppers-Totzek or Texaco partial-oxidation gasifiers were used). 28 In addition, as illustrated by Table 14, recent cost estimates for hydrogen from coal have ranged from about $\$ 2$ to $\$ 3$ per $10^{6} \mathrm{Btu}$, whereas hydrogen from water, via either potential water-splitting approaches or electrolysis, will probably cost $\$ 5$ to $\$ 10$ per $10^{6}$ Btu. 
ORNL.DWG 76-13256

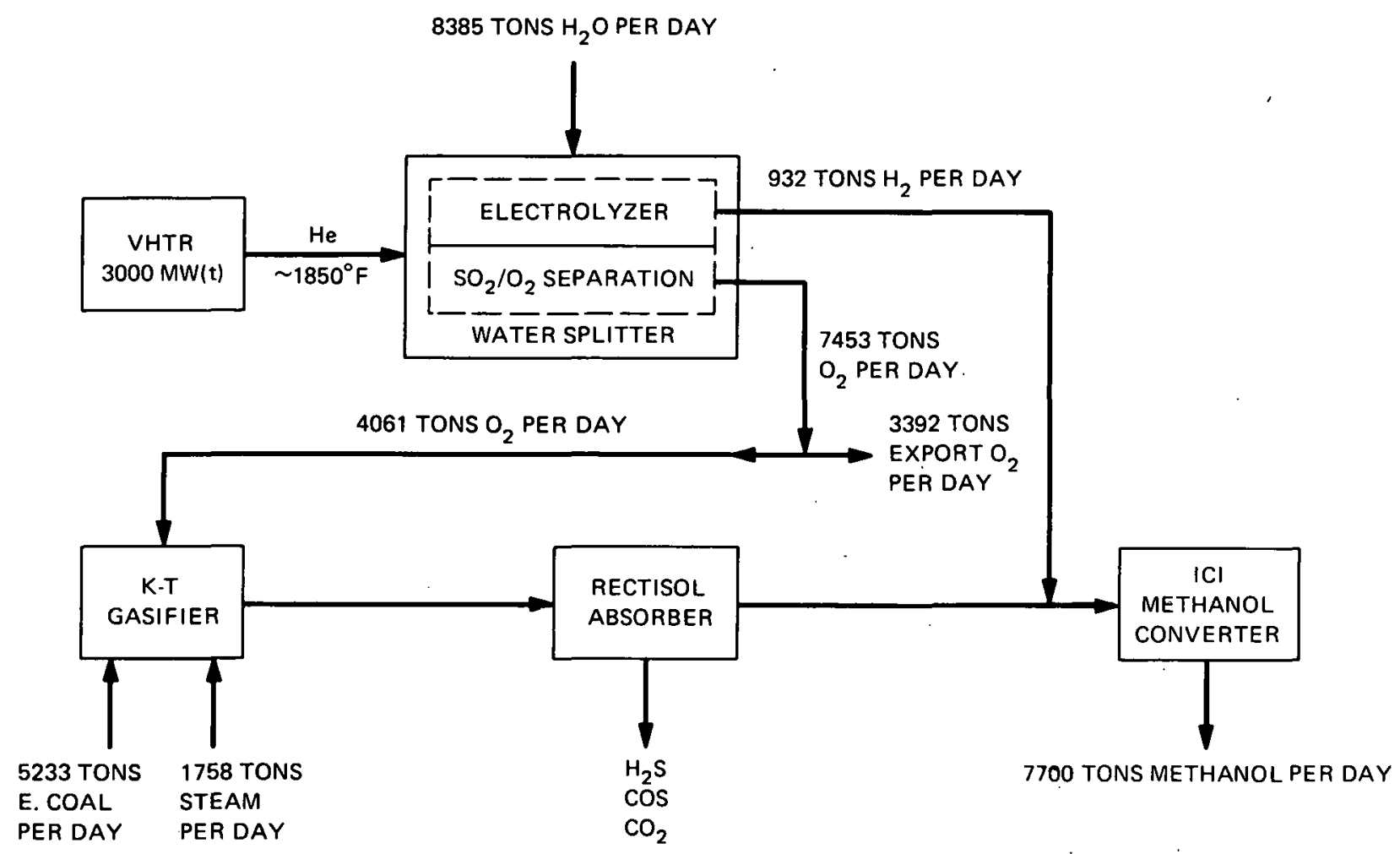

Fig. 6. Methanol production from coal using external hydrogen.

A calculation of the flows in an $\mathrm{H}$-Coal plant producing syncrude was also made, based on the existence of the same thermochemical hydrogen unit assumed previously. Using a net yield of $\mathrm{C}_{4}+$ liquid of $2.3 \mathrm{bbl} / \mathrm{ton}$ of dry coal as a basis, a coal heating value of $20 \times 10^{6} \mathrm{Btu} / \mathrm{ton}$, a hydrogen consumption of $7080 \mathrm{scf} / \mathrm{bbl}$ of $\mathrm{C}_{4}+1$ i.quid, and all hydrogen produced used in the process, the net effect would be to increase the syncrude yield by $54 \% .29$ Essentially all the oxygen would be available for export since process use is negligible. No coal would be used to make hydrogen (about $35 \%$ of the total coal feed normally would be required for this case), but the cost of hydrogen from water would again be about triple that from coal. In addition, the overall energy conversion efficiency would decrease from $66.3 \%$ to $54.6 \%$ (a decrement of about 12 percentage points). Using a higher and more probable hydrogen consumption of $8000 \mathrm{scf} / \mathrm{bbl}$ of $\mathrm{C}_{4}+$ liquid $\left(18,400 \mathrm{scf} \mathrm{H}_{2} /\right.$ ton of dry coal) to produce a light syncrude, the results are the same with the exception that the energy conversion efficiency would decline from $63.4 \%$ to $41.6 \%$ (a decrement of about 22 percentage points). The comparison clearly indicates that a heavy fuel oil product, requiring about 4000 
Table 14. Some recent cost estimates for hydrogen production

\begin{tabular}{|c|c|c|c|c|c|c|}
\hline Process & $\begin{array}{l}\text { GA/S\&W } \\
(\mathrm{coal})\end{array}$ & $\begin{array}{c}\mathrm{K}-\mathrm{T} \\
(\operatorname{coa} 1)\end{array}$ & $\begin{array}{l}\text { U-Gas } \\
(\operatorname{coal})\end{array}$ & $\begin{array}{l}\text { Westinghouse water } \\
\text { splitting }\end{array}$ & $\begin{array}{l}\text { Existing water } \\
\text { electrolysis }\end{array}$ & $\begin{array}{l}\text { Advanced water } \\
\text { electrolysis }\end{array}$ \\
\hline Output, $10^{9} \mathrm{Etu} / \mathrm{hr}$ & $15.6^{d}$ & 17.0 & 10.4 & 4.8 & 2.0 & 3.5 \\
\hline $\mathrm{H}_{2}$ purity, mole $\%$ & 88 & 97.5 & 94.3 & 99.9 & 99.9 & 99.9 \\
\hline $\begin{array}{l}\text { Approximate delivery } \\
\text { pressure, psia }\end{array}$ & 1000 & 1000 & 1000 & 1000 & 1000 & 1000 \\
\hline Efficiency, \% & 64 & 55 & 66 & 45 & 25 & 43 \\
\hline Capital cost,,$^{e} \$ 1 C^{6}$ & 1466 & 1180 & 540 & 1178 & 935 & 806 \\
\hline $\begin{array}{l}\text { Production cost, } \\
\$ / 10^{6} \mathrm{Btu}\end{array}$ & $2.33-4.95^{f}$ & $2.34-5.40^{f}$ & $2.17-3.00^{9}$ & $5.17-8.80^{f}$ & $9.88^{h}$ & $5.07^{h}$ \\
\hline Source reference & 1 & 1 & 2 & 1 & 3 & 3 \\
\hline
\end{tabular}

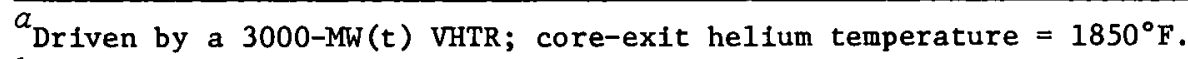

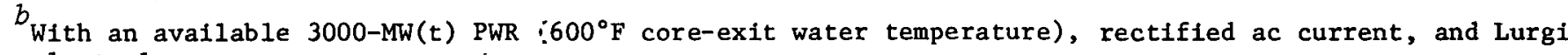
electrolyzers.

${ }^{c}$ Anticipated 1985 technology. A VHTR [3000 MW(t)] with a core-exit helium temperature of $1800^{\circ} \mathrm{F}, \mathrm{a}$ binary cycle $\left(\mathrm{He} / \mathrm{NH}_{3}\right)$, acyclic dc generators, and high-pressure solid-polymer electrolyte (SPE) electrolyzer technology. No intermediate heat-exchange loop.

$d_{\text {Output }}-18.3$ including liquid fuel production.

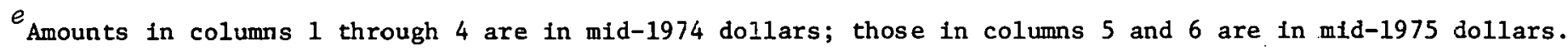

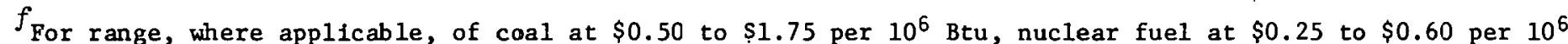
Btu, and fixed-charge rate (FCR) at $15 \%$ and $25 \%$ of total fixed investment.

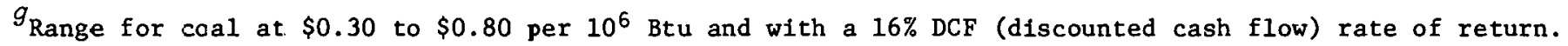

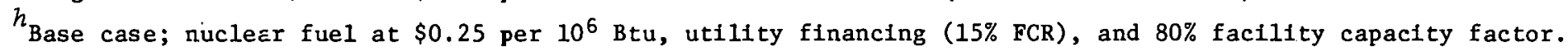
Sources:

1. J. J. Williams, D. S. Wiggins, and J. B. Newman, Engineering Evaluation of Process Heat Applications for Very High Temperature Nuclear Reactors, Report UE\&C/ERDA-750630 (Rev.), Mar. 9, 1976.

2. J. C. Gillis et al., Survey of Hydrogen Production and Utilization Methods, vol. 2, Institute of Gas Technolog;, August 1975, Sect. 5, pp. 82-107.

3. W. J. D. Escher et al., A Preliminary Systems Engineering Study of con Advanced NuolearElectrolztic Pydroger-Production Facility, Institute of Gas Technology, December 1975. 
scf $\mathrm{H}_{2} / \mathrm{bbl}$, would be relatively more attractive for the external hydrogen supply case. In any event, hydrogen from water will not be competitive with hydrogen from coal until coal prices increase to much higher levels. The Institute of Gas Technology has independently investigated the use of external hydrogen in the conversion of coal to substitute natural gas (SNG), low-Btu gas (not amenable), methanol, and liquid hydrocarbons, and of oil shale to liquids and gases (not easily integrated with currently proposed retorting approaches). ${ }^{30}$ A preliminary economic analysis was performed with costs based on constant 1973 dollars and a $12 \%$ discounted cash flow rate. It was estimated that for outside hydrogen at $\$ 4.10$ per $10^{6} \mathrm{Btu}$, the break-even coal cost (beyond which external hydrogen is favored) is $\$ 1.15$ per $10^{6}$ Btu for producing methanol, $\$ 3.20$ per $10^{6} \mathrm{Btu}$ for SNG production, and $\$ 3.74$ per $10^{6} \mathrm{Btu}$ for gasoline using the Consol Synthetic Fuel (CSF) process. 25 The corresponding product prices were calculated to be $\$ 115$ per ton for methanol $\$ 0.38 /$ gal, the late1975 sales price), $\$ 6.52 / \mathrm{Mscf}$ for SNG, and $\$ 54.52 / \mathrm{bbl}$ for gasoline ( $\$ 1.30 / \mathrm{gal}$ ).

\subsubsection{Advantages and disadvantages of nuclear coal conversion}

The three reasons generally cited for developing this technology are (1) that it will save coal (reduce mining); (2) that a GCR/coal complex might produce less expensive products; and (3) that it could reduce the environmental impacts of coal-conversion plants. These points are addressed in the following sections.

\subsubsection{Coal conversion}

The country's proven (recoverable at current cost levels with current mining techniques) coal reserve of $434 \times 10^{y}$ tons (ref. 31) would last 680 years at the 1975 production rate if it could all be recovered. Assuming an overall recovery factor of $70 \%$ and a fourfold increase in mining rate to $2.55 \times 10^{9}$ tons per year, the reserve would last a little over a century. However, as coal rises in price, the amount that is economically recoverable will increase.

If one accepts the ORNL estimates of synthetic fuels production from coal, production increases from about $1.2 \times 10^{15}$ Btu per year in 1985 to $15 \times 10^{15} \mathrm{Btu}$ per year in the year 2000. The VHTR share of this production, on a very optimistic basis, reaches $4.5 \times 10^{15} \mathrm{Btu}$ per year in the year 2000 after the lead plant is introduced about 1995. The amount of coal saved by using the VHTR (assuming the all-fossil plants use 1.3 times as much coal as the VHTR coal-conversion plants) would be $1.35 \times 10^{15}$ Btu in the year 2000 or about $2.4 \%$ of the coal to be mined in that year.

Most current estimates of synthetic fuels production are below the ORNL estimates. For example, the following December 1975 energy projections of Dupree and Corsentino ${ }^{32}$ show that if coal resources are to be "saved," the electric utility sector and the industrial sector are more attractive targets than the nascent synthetic fuels industry. 
Coal energy for synfuels

Fossil fuels for electric utilities

Fossil fuels for industry $a$
Quad per year

\begin{tabular}{rrr}
\hline 1980 & 1985 & \multicolumn{1}{c}{2000} \\
\hline 0 & 0.52 & 8.14 \\
19.35 & 23.40 & 26.40 \\
22.30 & 22.80 & 25.28
\end{tabular}

$\overline{a_{\text {Excluding use }}}$ of synfuels and electricity.

The use of the VHTR to conserve coal cannot have a significant impact until well into the 21st century. By that time, substitution of nuclear fuels for coal will be sound conservation practice if the breeder reactor is successful in extending the nuclear fuel resource base. Without the breeder, the desirability of working low-grade uranium resources will have to be weighed against the use of fossil resources.

\subsubsection{Economics}

The nuclear-coal hybrid systems (hydrogasification, solution hydrocracking, and steam gasification) appear to be feasible both technically and economically at the high end of the coal price range investigated $-\$ 1.75$ per $10^{6}$ Btu. The all-fossil systems are economically better at coal prices of $\$ 0.50$ per $10^{6} \mathrm{Btu}$. The difference in cost between nuclear and all-fossil systems is less than the uncertainty in the cost of either one.

It is very difficult to predict when the price of coal will escalate to the extent that nuclear energy will become the preferred source of steam and hydrogen for coal-conversion systems.

\subsubsection{Environwental conslderations}

Projected $\mathrm{SO}_{2}$, $\mathrm{NO}_{\mathrm{x}}$, particulate, and bulk solid-waste environmental loadings from plants using nuclear process heat can be five- to thirtyfold (usually two- to flvefold) below those of equivalent fossil-fueled plants. However, the pollutant outputs of the latter can apparently be held well below current EPA power plant standards. The nuclear variant, of course, produces radwastes which are unassociated with fossil-tueled plants. An evaluation of pollution and water consumption for selected coal-conversion processes was prepared by UE\&C under subcontract to ORNL. 33

The question that must be considered is whether very large coalconversion plants will be acceptable to the public, when considering current EPA standards. The incremental (about fivefold) reduction in environmental pollution with the nuclear coal-conversion alternative could become attractive as more demanding environmental protection measures are required. 


\subsubsection{Institutional considerations}

It is quite evident that commercialization of synthetic fuels production requires the solution of difficult institutional problems such as adequate industrial participation, venture capital, political and environmental opposition; and the threat of price competition from imported oil. Combining the above problems with the technological and licensing problems of nuclear reactors will create even greater commercial risks.

Very clear economic and environmental advantages will have to be demonstrated for nuclear coal conversion before it can be accepted by industry.

\subsubsection{Conclusions and recommendations for nuclear coal conversion}

The impact of VHTRs applied to coal conversion in the United States could not become significant until after the year 2000. Careful examination of all aspects is needed before any decisions are made regarding a major program on nuclear process heat for coal conversion.

Coal hydrogasification, coal solution hydrocracking, and steam coal gasification all appear to be potentially applicable to nuclear coal conversion. The use of the VHTR in steam reforming of light hydrocarbons to produce hydrogen for use in coal conversion is the most reasonable near-term coupling scheme. The indirectly heated steam-coal fluidized bed is a promising longer-range coupling scheme requiring more research and development (R\&D). This scheme generally requires higher temperatures than reforming, or it requires catalyzed coal.

The use of the VHTR to produce hydrogen for coal conversion via thermochemical or electrolytic water splitting is not currently economically competitive with hydrogen derived from coal. Because of coal's interaction with the other fuel sources and possible political and environmental constraints to its accelerated development, it is difficult to estimate when hydrogen via water splitting will be competitive. However, it is clear that this is an important future concept that requires development before carbonaceous fuels are in short supply.

Although the first VHTR plant could not reasonably be operated in the United States before 1995, the lead time for process development is such that $R \& D$ must start at a reasonable rate about 20 years before the start of operation and 10 years before the start of lead plant construction. Three areas of $R \& D$ are recommended:

1. Development of processes for producing hydrogen and synthesis gas via nuclear-heated steam-light hydrocarbon reforming. Program tasks are expected to be (a) the definition of carbon feedstocks to the overall process; (b) the definition of commercial or near-commercial process elements; (c) the identification of missing process links; (d) laboratory- and pilot-plant scale R\&D on needed process elements; (e) R\&D relating to use of chars; (f) R\&D relating to standards for the hydrocarbon feed to the reformer (e.g., maximum acceptable impurity levels from the corrosion point of view); ( $g$ ) development of materials technology; and (h) development of an overall system concept. 
2. Development of nuclear coal conversion processes for producing synthetic pipeline gas (SPG) and liquids. Program tasks are expected to include (a) the definition of appropriate commercial or near-commercial process elements; (b) the definition of missing process links; (c) $R \& D$ on steam-coal and steam-char indirectly heated processes; and (d) development of preferred overall system concepts for the production of liquids and SPG. Key objectives are to evolve simple coal-conversion systems, if possible; to minimize char production; and to find the proper choice of nuclear process heat temperature and process efficiency. A great deal of technology will be developed in Germany; it would be desirable to gain access to the results of that work.

3. 'Thermochemical water splitting. Water-splitting processes to provide external sources of hydrogen are expected ultimately to become so important that $R \& D$ is justified now. Recommended steps include (a) laboratory investigation of the kinetics of key process steps; (b) thermodynamic measurements; (c) thermodynamic analysis of alternative cycles to make best use of practical process steps; and (d) limited engineering-scale tests.

\subsection{Nuclear Steelmaking}

The most viable concept for applying nuclear energy to steelmaking combines two well-known processes: (1) direct reduction in a shaft furnace and (2) refining in an electric furnace.

Although direct reduction of iron ore is a fairly new process, it is well developed and is in commercial use in various parts of the world where low-cost natural gas is available. In this process, iron ore is reduced in the solid condition to a product known as sponge iron by a synthesis gas $\left(\mathrm{CO}+\mathrm{II}_{2}\right)$ derived from steam reforming of natural gas. The reaction requires high-temperature heat. Nuclear energy could be used to provide the heat needed to produce synthesis gas for the direct reduction of iron ore. Electricity needed to refine the resulting sponge iron to steel in an electric-arc furnace may also be provided by nuclear energy, but the furnace would likely be at a remote site.

Production of steel by electric-arc furnaces is a long-established commercial technology. Almost all of that tonnage is made with scrap as the only ferrous charge, although a number of plants currently use at least some sponge iron in their charges. Sponge iron could be used for a large portion of that charge, if the cost of the sponge were competitive with scrap. Electric-arc refining uses about $650 \mathrm{kWhr} /$ ton of steel.

Processes for direct reduction differ in certain details, but almost all of them use as a reductant a gas mixture of carbon monoxide and hydrogen at temperatures of $816^{\circ}$ to $982^{\circ} \mathrm{C}\left(1500^{\circ}\right.$ to $\left.1800^{\circ} \mathrm{F}\right)$. For the efficient reduction of iron ore, the $\mathrm{CO}+\mathrm{H}_{2}$ content of the reducing gas should be above $90 \%$.

The American Iron and Steel Institute (AISI) has studied nuclear steelmaking $34-39$ with syngas produced via steam reforming of natural gas and with syngas produced from coal via the GA/S\&W process. A reformer exit temperature of $760^{\circ} \mathrm{C}\left(1400^{\circ} \mathrm{F}\right)$ was found to be acceptable, although 
$816^{\circ}$ to $871^{\circ} \mathrm{C}\left(1500^{\circ}\right.$ to $\left.1600^{\circ} \mathrm{F}\right)$ is preferred. Nuclear steelmaking was found by D. J. Blickwede, AISI, to be competitive with conventional blast furnace technology and with a coal gasification direct reduction process (metallurgical coal assumed at $\$ 55 /$ ton and nonmetallurgical coal at $\$ 25 /$ ton $) .38$

United Engineers and Constructors, under contract with.ORNL, also evaluated nuclear steelmaking. ${ }^{40}$ An economic comparison was made for four alternatives for producing steel. These are as follows:

Case 1. Conventional coke oven/blast furnace/basic-oxygen furnace refining (Fig. 7).

Case 2. Conventional reforming of natural gas/direct reduction/electricarc furnace refining (Fig. 8).

Case 3. General Atomic Stone and Webster synthesis gas feed/direct reduction/electric-arc furnace refining (Fig. 9).

Case 4. Koppers-Totzek synthesis gas feed/direct reduction/electricarc furnace refining (Fig. 10).

Case 3 utilizes the VHTR in the production of synthesis gas via the $\mathrm{GA} / \mathrm{S} \& W$ process.

In this analysis the nuclear option (Case 3) appeared to be competitive with the conventional coke oven/blast furnace process (Case 1) and with the direct reduction process using synthesis gas from a KoppersTotzek gasifier (Case 4). It was not competitive with synthesis gas from a conventional natural gas reformer using current rates for natural gas. However, the anticipated lifting of regulations on natural gas prices would result in a much more favorable cost comparison. The availability of natural gas for this application whether or not regulations on gas prices are lifted may be questionable because of limited supplies.

Size mismatch is a major problem in considering nuclear steelmaking. The electric-furnace capacity in the United States today is about 30 million tons/year. A single $3000-\mathrm{MW}(t)$ VHTR dedicated to nuclear steelmaking would produce 14 million tons/year of sponge iron. It would be almost impossible to absorb so large a plant into the industry. Therefore, one is required to think of a VHTR producing synthesis gas for a number of applications (steelmaking, ammonia synthesis, coal conversion, and/or petroleum refining) at a single site. This appears to be an attractive approach, but it will undoubtedly be very difficult to organize a joint project with many participants.

The steel industry does not appear to require a large number of VHTR units, but it may be a very important customer. The Japanese have launched a major program in nuclear steelmaking, allocating about $\$ 26$ million over a six-year period. ${ }^{41}$. Nuclear steelmaking technology may be required to keep the U.S. steel industry competitive in the future. 
ORNL-OWG 76-13250

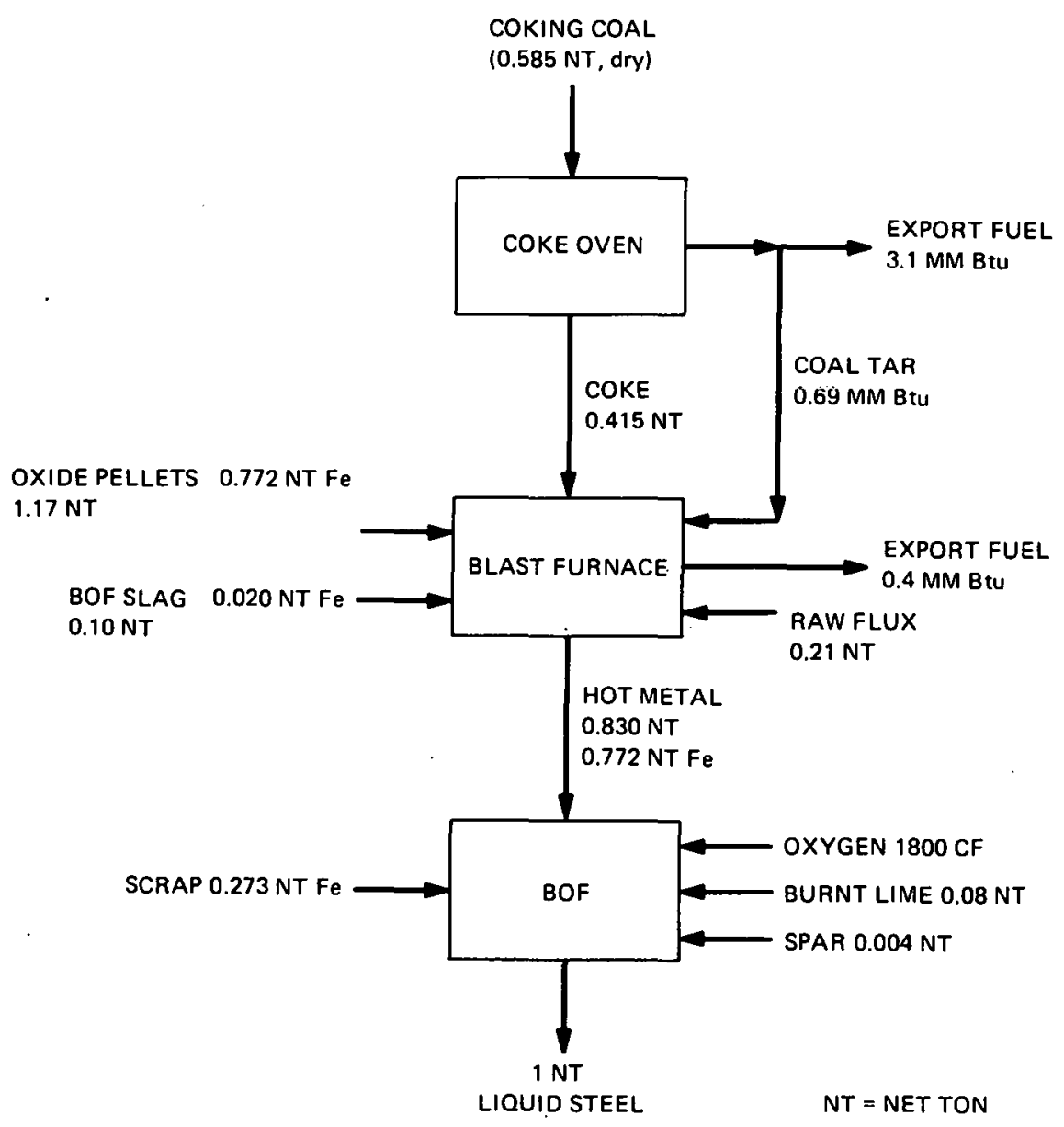

Fig. 7. Case 1 flowsheet for steel production by coke oven/blast furnace/ basic-oxygen furnace (BOF) refining.

\subsection{Petroleum Refinery}

At the request of ORNL, the General Atomic Company conducted a study ${ }^{42}$ to evaluate the use of the General. Atomic high-temperature gas-cooled reactor (HTGR) as a heat source for petroleum refining and other petrochemical processes. The study investigated the technical and economic aspects of producing and transporting $1364 \mathrm{MW}(t)$ energy to a refinery, the boundary of which was located $3500 \mathrm{ft}$ from the reactor. The refinery heat load was made up nf $398 \mathrm{MW}$ of $371^{\circ} \mathrm{C}\left(700^{\circ} \mathrm{F}\right)$ steam and $966 \mathrm{MW}$ of process heat having the capability of producing refinery process temperatures of $566^{\circ} \mathrm{C}\left(1050^{\circ} \mathrm{F}\right)$. The basic refinery heat balance used in the study was provided by Amoco Oil Company. Shell Oil Company supplied additional data on refinery heat loads, shutdown schedules, and hydrogen requirements. A schematic of a single-reactor configuration with fossilfuel backup is shown in Fig. 11 . 
ORNL-DWG 76-13251

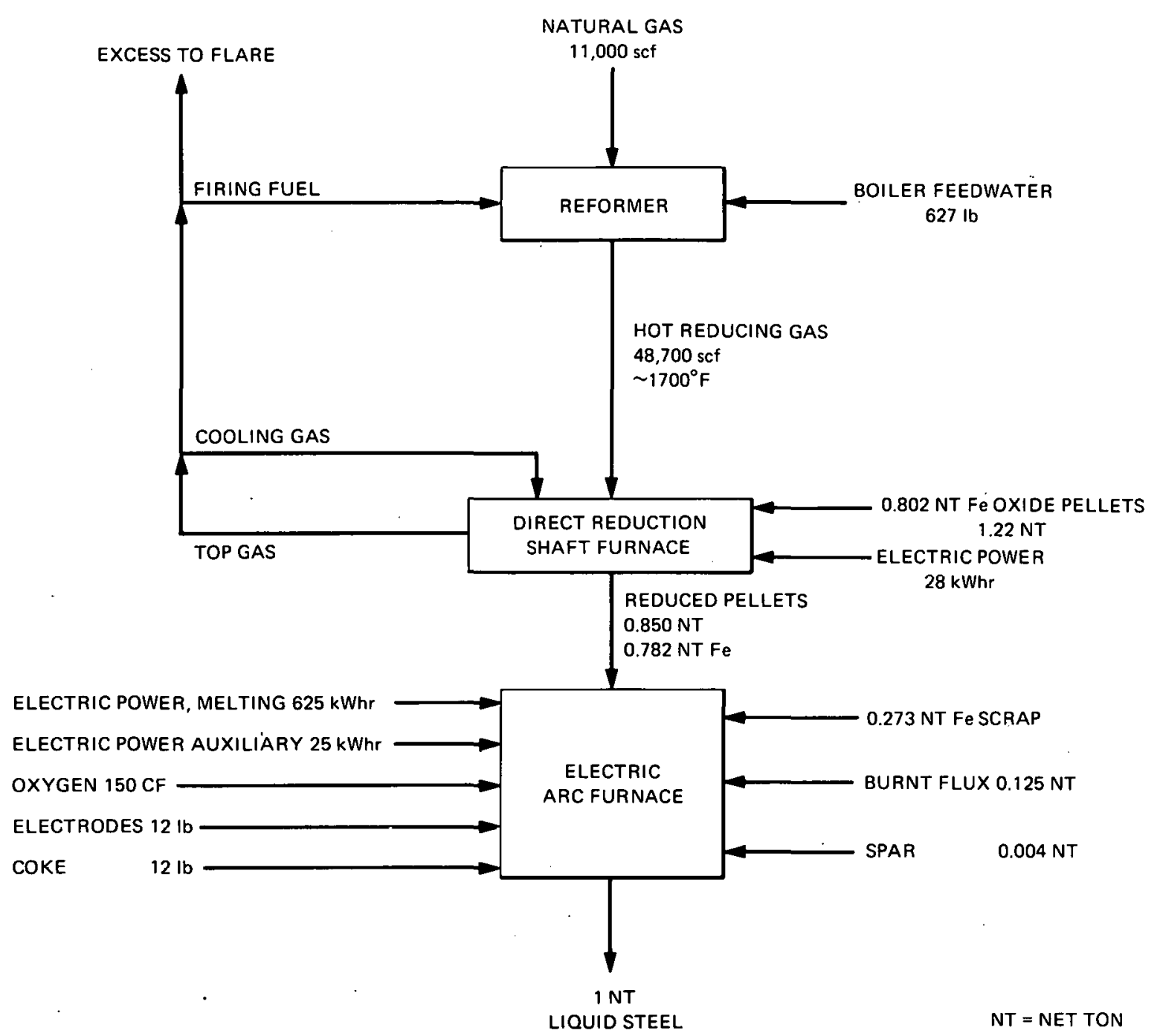

Fig. 8. Case 2 flowsheet for steel production by natural gas reformer/ direct reduction/electric arc furnace (EAF) refining.

In the commercial steam-producing HTGR, the major reactor system components such as the reactor core, control-rod drive assemblies, helium circulators, steam generators, and core auxiliary cooling system are contained within a prestressed concrete reactor vesse1 (PCRV). For the heat transport study a $2000 \mathrm{MW}(t)$ reactor was used. Two major modifications were made to the PCRV internals: (1) the steam generators were replaced by primary-to-secondary-helium heat exchangers; and (2) the number of primary reactor cooling loops was reduced from four to three.

The helium/helium heat exchangers located inside the PCRV are used to transfer heat from the primary reactor cooling loops to secondary or intermediate heat transfer loops. The reactor heat is then transferred to steam generators and to a fluid that transports heat to the refinery. 
ORNL-DWG 76-13252

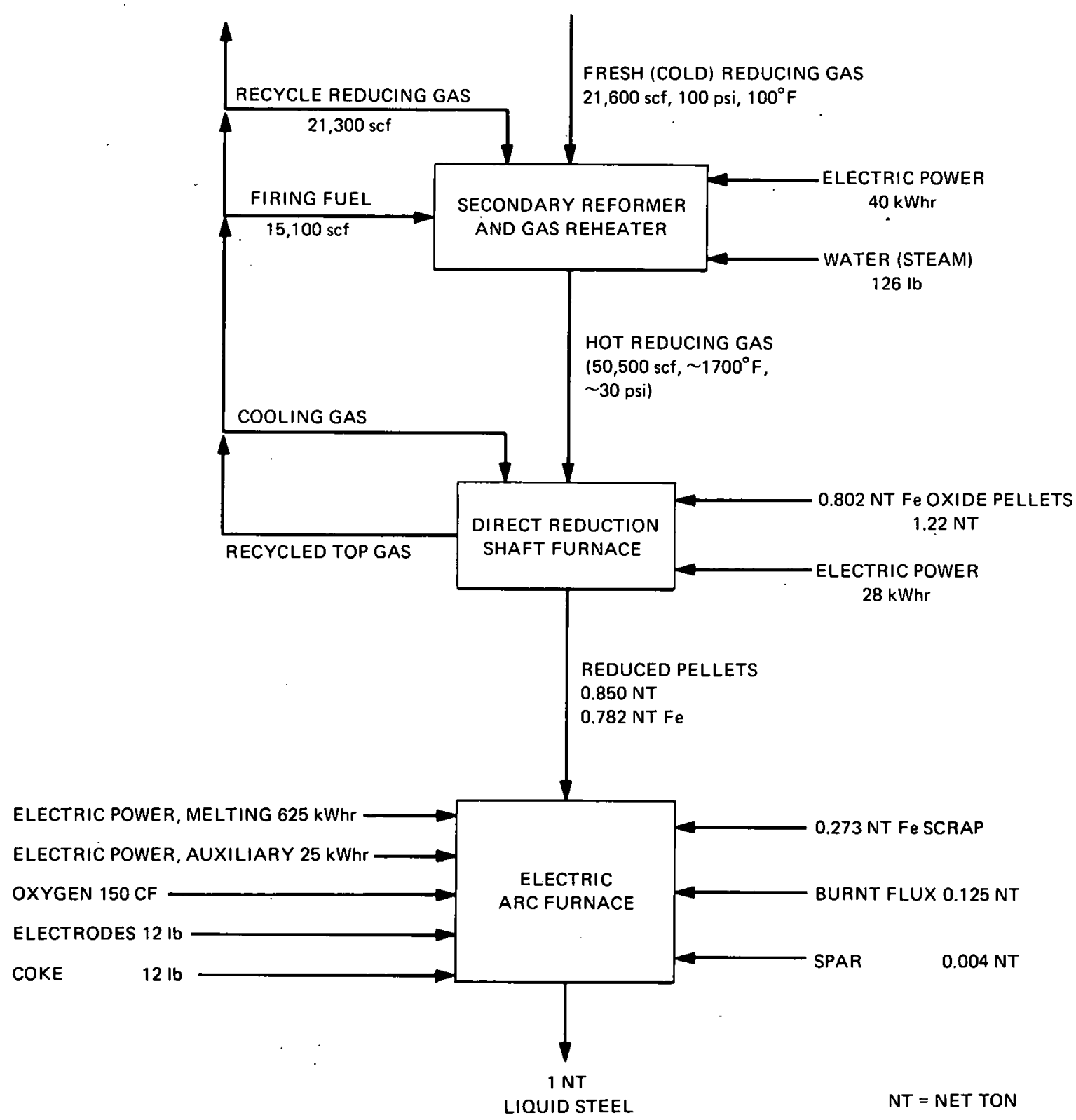

Fig. 9. Case 3 flowsheet for steel production by General Atomic VHTR/ direct reduction/electric arc furnace (EAF) refining. 
ORNL-DWG 76-13253

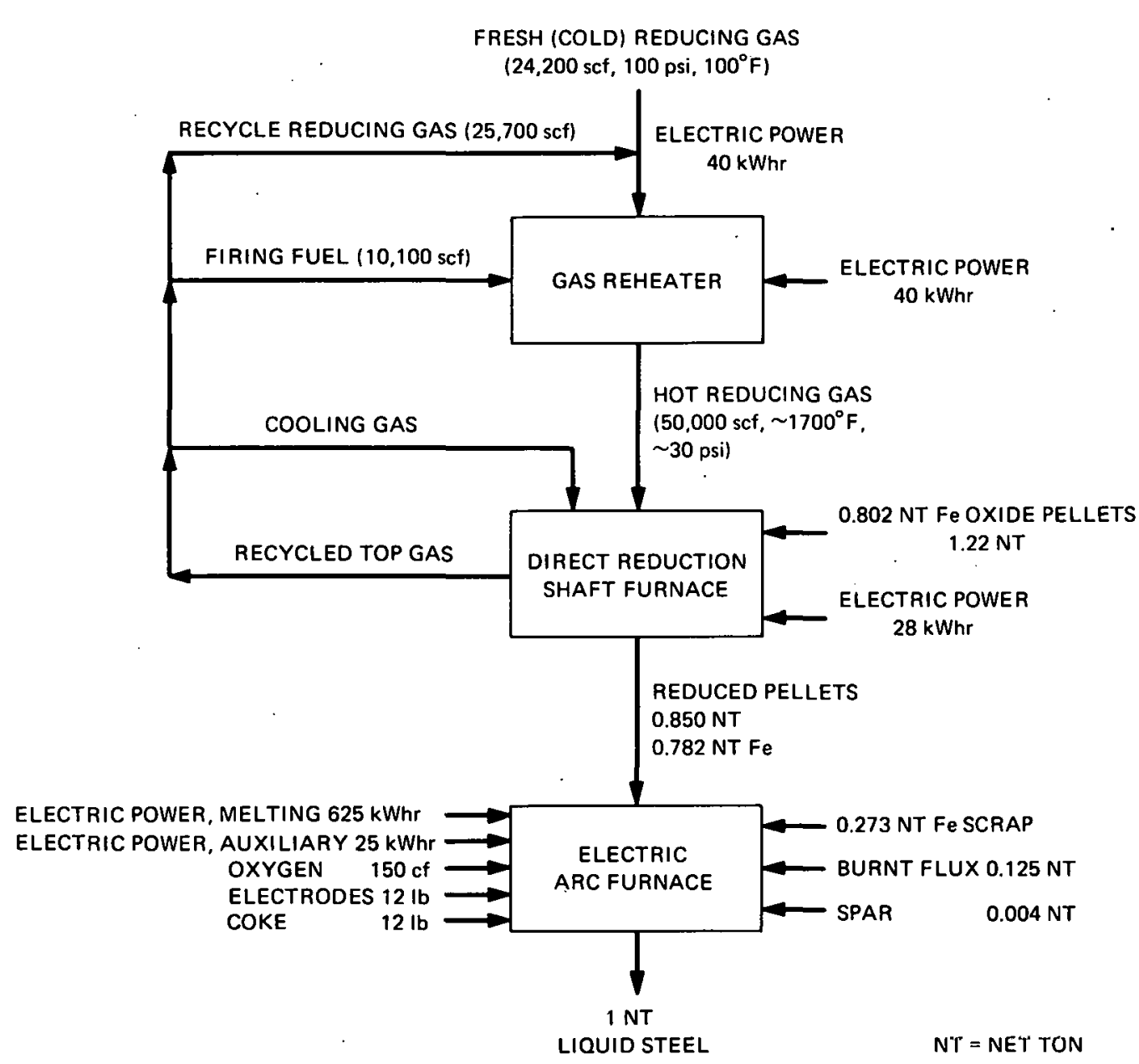

Fig. 10. Case 4 flowsheet for steel production by Koppers-Totzek/ reformer/direct reduction/electric arc furnace (EAF) refining.

The selection of a heat transport fluid was carried out by evaluating a number of candidate fluids; sizing piping systems for refinery supply and return; establishing piping pressure drops, heat losses, and required pumping powers; establishing helium-to-heat-transport-fluid heat exchanger designs; and, finally, establishing cost estimates for each of the systems. Candidate heat transport fluids are listed in Table 15, along with a discussion of some advantages and disadvantages of each. Heat transport fluid piping data and costs are given in Tables 16-18.

A piping system that would supply the heat transport fluid to the refinery and return it to the process heat exchangers at the reactor was sized for the configuration using dual reactors with process steam generated at the refinery, and a cost estimate was established for each of the candidate heat transport fluids. The flow rate for a given fluid was determined from the refinery heat load $\left(4656 \times 10^{6} \mathrm{Btu} / \mathrm{hr}\right)$ and the fluid enthalpy or specific heat at the $593^{\circ} \mathrm{C}\left(1100^{\circ} \mathrm{F}\right)$ refinery supply 
Table 15. Candidate heat transfer fluids

\begin{tabular}{|c|c|c|}
\hline Fluid & Advantages & Disadvantages \\
\hline Helium & $\begin{array}{l}\text { Chemically inactive; } \\
\text { thermally stable; low } \\
\text { viscosity; already used } \\
\text { in primary and second- } \\
\text { ary coolant loops for } \\
\text { HTGR. }\end{array}$ & Expensive. \\
\hline Hydrogen & $\begin{array}{l}\text { Thermally stable; good } \\
\text { heat transfer proper- } \\
\text { ties; low viscosity; } \\
\text { low pumping power; } \\
\text { common fluid in } \\
\text { refinery. }\end{array}$ & $\begin{array}{l}\text { Explosive with air; } \\
\text { may have adverse } \\
\text { effects on steel at } \\
\text { elevated temperatures. }\end{array}$ \\
\hline Nitrogen & Cheap; inert. & $\begin{array}{l}\text { Poor combination of } \\
\text { heat transfer and flow } \\
\text { properties; high } \\
\text { pumping power. }\end{array}$ \\
\hline Steam & $\begin{array}{l}\text { Cheap; wel1-known } \\
\text { fluid. }\end{array}$ & Corrosive. \\
\hline Carbon dioxide & $\begin{array}{l}\text { Cheap; used as reactor } \\
\text { coolant; high-heat } \\
\text { carrying capacity. }\end{array}$ & $\begin{array}{l}\text { Corrosive in presence } \\
\text { of water; poor heat } \\
\text { transfer; high pumping } \\
\text { power. }\end{array}$ \\
\hline $\begin{array}{l}\text { Heat transfer } \\
\text { salt (HTS) }\end{array}$ & $\begin{array}{l}\text { High specific heat per } \\
\text { unit volume; high heat } \\
\text { transfer coefficient; } \\
\text { nonfouling; cheap. }\end{array}$ & $\begin{array}{l}\text { High freezing point; } \\
\text { relatively high vis- } \\
\text { cosity; is at the } \\
\text { limit of its thermal } \\
\text { stability; no internal } \\
\text { insulation possible. }\end{array}$ \\
\hline $\begin{array}{l}\text { Sodium potassium } \\
\text { alloy (NaK) }\end{array}$ & $\begin{array}{l}\text { Thermally stable; high } \\
\text { specific heat per unit } \\
\text { volume; excellent heat } \\
\text { transfer properties; } \\
\text { low viscosity, low } \\
\text { freezing point, high } \\
\text { boiling point; low } \\
\text { vapor pressure. }\end{array}$ & $\begin{array}{l}\text { Highly chemically } \\
\text { active with air and } \\
\text { water; no internal } \\
\text { insulation possible; } \\
\text { corrosive above } 500^{\circ} \mathrm{C} \\
\left(932^{\circ} \mathrm{F}\right) \text {. }\end{array}$ \\
\hline
\end{tabular}


temperature and the $329^{\circ} \mathrm{C}\left(625^{\circ} \mathrm{F}\right)$ refinery return temperature. Table 16 presents design data for the fluid piping systems.

A preliminary analysis was also performed to establish helium-toheat-transport-fluid heat exchanger designs for each of the candidate fluids.

The heat exchanger heat load and $\log$ mean temperature difference were the same for all cases. The heat exchanger heat transfer area was, therefore, a function of the overall heat transfer coefficient. The helium (she1l) side heat transfer coefficient is the same for all cases so that the heat transfer area is a function of the heat-transport-fluid heat transfer coefficient. The computed heat exchanger heat transfer areas are presented in Table 17. Sodium potassium alloy has the lowest heat transfer area because it has the highest heat transfer coefficient. Table 18 presents heat transport loop cost for each of the candidate heat transport fluids. These data are based on a heat exchanger cost of $\$ 20 / \mathrm{ft}^{2}$ of heat transfer area.

The data in Table 18 show a significant cost advantage for HTS. Heat transfer salt, the selected fluid, is a eutectic mixture of potassium nitrate, sodium nitrite, and sodium nitrate. It is cheap, does not foul the heat exchangers, and has very good heat transfer characteristics. Also, because of its high density when compared with a gas, its heat transport capacity is much higher than for gases. For engineering purposes sufficient data are available. Disadvantages are its relatively high viscosity and its high freezing point, which will require steam tracing for startup and shutdown. For this application it will be used up to its thermal stability limit. Because internal insulation cannot be used, higher pipe temperatures will require more expensive pipe material.

Two basic approaches were investigated for providing a backup refinery source when the reactor is shut down. These were: (1) the use of a fossil fuel heater capable of supplying $67 \%$ of the refinery heat load and (2) the use of dual 2000-MW(t) reactors. The single reactor configuration was limited to the case where the refinery steam requirement was generated at the refinery site, whereas the dual reactor configuration considered generation of the refinery steam at both the reactor site and the refinery site.

A flow schematic of the single reactor configuration is shown in Fig. 11. The fossil fuel heater, which is a part of the heat transport loop, is located at the refinery site. The heater has the capacity of providing $67 \%$ of the refinery heat load, that is, $914 \mathrm{MW}(\mathrm{t})$. When the reactor is operating, the fossil fuel heater is on-line at $25 \%$ of its design capacity, that is, $228.5 \mathrm{MW}(t)$.

A flow schematic of the duel reactor with steam generated at the refinery is shown in Fig. 12. The configuration for one reactor only is shown. During normal operation, each reactor supplies $50 \%$ of the necessary energy to the heat transport loop. The reactor primary coolant and the secondary coolant loop conditions are the same as in the previously discussed case. The secondary loop helium, after being heated to $704^{\circ} \mathrm{C}\left(1300^{\circ} \mathrm{F}\right)$ in the primary-to-secondary helium heat exchanger, splits into two parallel streams with $50 \%$ of the flow going to the process heater and $50 \%$ to a secondary steam loop equipped with a 
ORNL-DWG $76-20622$

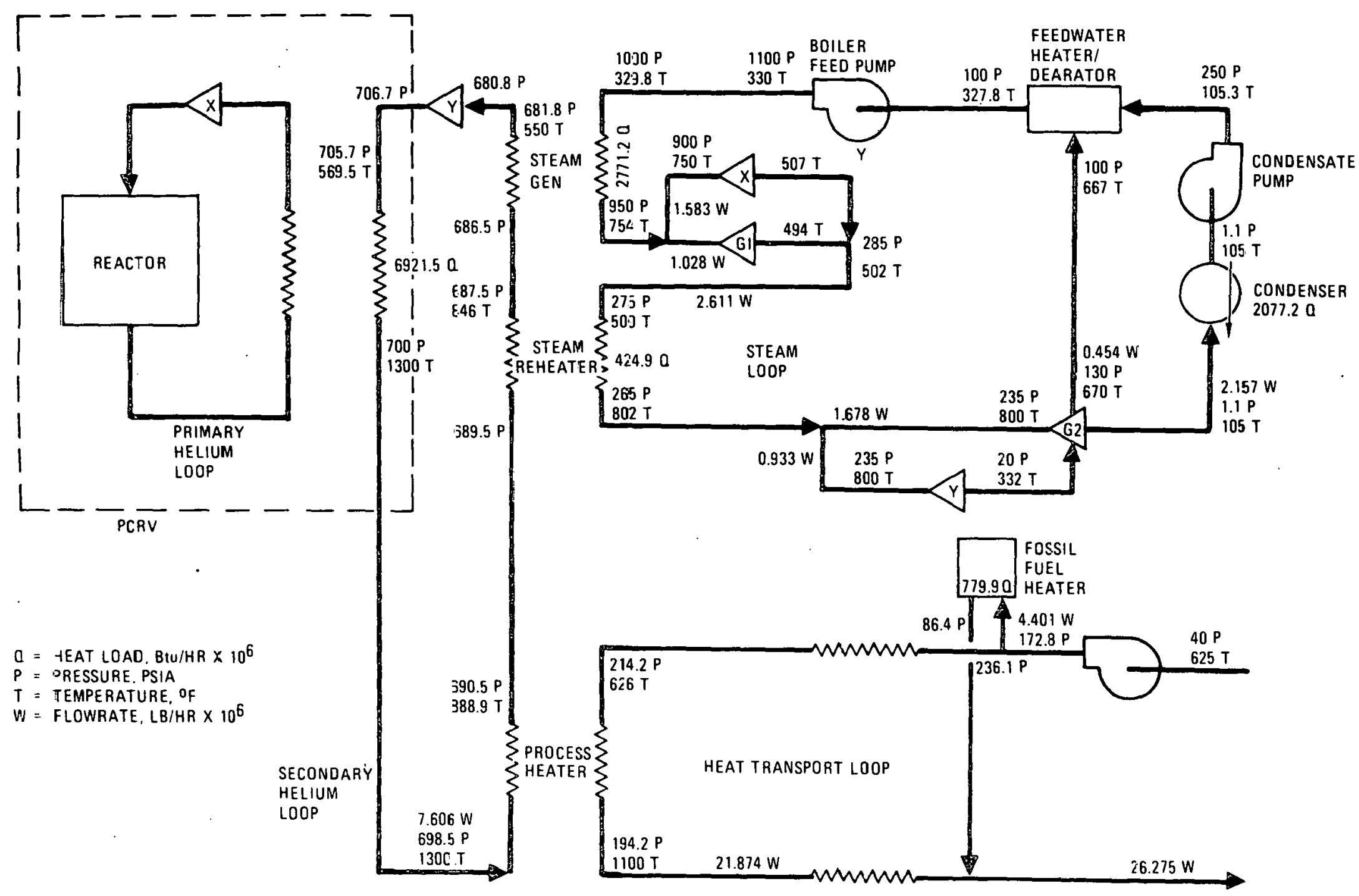

Fig. 11. Schematic of single-reactor configuration fossil-fuel backup. 
Table 16. Heat transport fluid piping system data

\begin{tabular}{|c|c|c|c|c|c|c|c|}
\hline Characteristics & Helium & Hydrogen: & Nitrogen & $\begin{array}{l}\text { Carbon } \\
\text { Dioxide }\end{array}$ & Steam & HTS & $\mathrm{NaK}$ \\
\hline Flow rate, $10^{6} 1 \mathrm{~b} / \mathrm{hr}$ & 7.840 & 2.801 & 36.719 & 35.651 & 17.406 & 26.275 & 46.855 \\
\hline Inventory, $1 \mathrm{~b}$ & 152,450 & 48,410 & $1,269,340$ & $1,540,520$ & 615,380 & $11,837,000$ & $8,528,850$ \\
\hline Supply pipe $O D,{ }^{a, b} \mathrm{ft}$ & 10.07 & 7.862 & 11.75 & 11.23 & 8.758 & 3.747 & 4.746 \\
\hline Return pipe oD, ${ }^{C} \mathrm{ft}$ & 9.85 & 7.199 & 11.22 & 10.85 & 8.299 & 3.788 & 4.533 \\
\hline $\begin{array}{l}\text { Supply pipe velocity, } \\
\text { fps }\end{array}$ & 250 & 275 & 135 & 110 & 140 & 11.0 & 25 \\
\hline $\begin{array}{l}\text { Return pipe velocity, } \\
\text { fps }\end{array}$ & 150 & 175 & 90 & 70 & 80 & 63 & 17.7 \\
\hline $\begin{array}{l}\text { Pump or circulator } \\
\text { inlet pressure, psia }\end{array}$ & 622 & 721 & 533 & 438 & 723 & 40 & 40 \\
\hline $\begin{array}{l}\text { Pump or circulator } \\
\text { outlet pressure, psia }\end{array}$ & 667 & 767 & 597 & 496 & 805 & 172 & 283 \\
\hline $\begin{array}{l}\text { Pump or circulator } \\
\text { power, } M W(t)\end{array}$ & 108 & 65.2 & 122 & 79.8 & 71.5 & 1.93 & 146 \\
\hline $\begin{array}{l}\text { Supply pipe wall } \\
\text { thickness, in. }\end{array}$ & 2.58 & 2.30 & 2.71 & 2.15 & 2.70 & 0.318 & 0.648 \\
\hline $\begin{array}{l}\text { Return pipe wall } \\
\text { thickness, in.. }\end{array}$ & 2.38 & 2.00 & 2.37 & 1.89 & 2.34 & 0.200 & 0.201 \\
\hline $\begin{array}{l}\text { Piping heat loss, } \\
10^{6} \mathrm{Btu} / \mathrm{hr}\end{array}$ & 39.6 & 30.3 & 46.1 & 44.4 & 34.0 & 10.3 & 13.4 \\
\hline
\end{tabular}

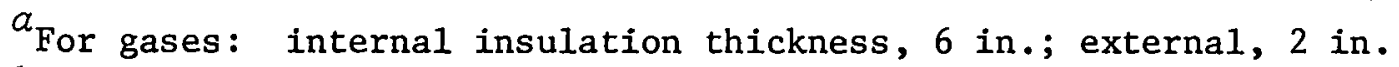

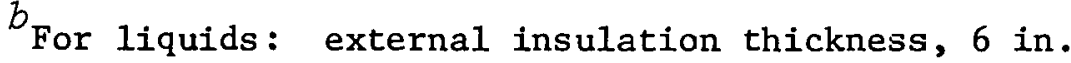

${ }^{c}$ All cases: outer insulation thickness, 2 in. 
Table 17. Process heat exchanger heat transfer areas $\left(\mathrm{ft}^{2}\right)$

\begin{tabular}{ccccccc}
\hline Helium & $\mathrm{H}_{2}$ & $\mathrm{~N}_{2}$ & $\mathrm{CO}_{2}$ & $\mathrm{H}_{2} \mathrm{O}$ & $\mathrm{HTS}$ & $\mathrm{NaK}$ \\
\hline 226,180 & 206,900 & 280,370 & 276,460 & 274,000 & 180,000 & 128,100 \\
\hline
\end{tabular}

reheater-steam generator combination. This secondary steam loop generates 284 MW(e) of power.

The two $50 \%$ streams then recombine and flow to a reheater-steam generator combination in the primary steam loop. The primary steam loop provides the power to drive the primary and secondary helium circulators (marked "X" and "Y," respectively, in Fig. 12) and to supply additional 117 MW(e) of power.

A flow schematic for the dual reactor configuration with steam generated at the reactor is shown in Fig. 13. With two exceptions, this cycle is identical to the dual reactor configuration with steam generated at the refinery: (1) a refinery steam loop is added; and (2) the steam supply for the feedwater heater in the secondary steam loop is extracted from the primary steam loop power turbine.

The reactor cooling loop is identical for the three cycle configurations. The 2000-MW(t) reactor core is cooled by three helium loops. Each loop has a steam-turbine-driven helium circulator. Reactor heat is transferred from the primary helium loops to the secondary helium loops by three single-pass heat exchangers. The reactor core, along with the primary cooling loops, the primary circulators, and the helium/ helium heat exchangers are located inside a PCRV. With the exception of the helium/helium heat exchangers, the design of the primary cooling loops is similar to those of the HTGR steam plant. Figure 14 is a schematic of the primary cooling loop. The flow rates, heat loads, and circulator powers shown are the totals for three loops.

An economic evaluation of the three cycle configurations was made by developing and comparing the total annual costs of each configuration. Capital costs for both the nuclear steam supply (NSS) and balance of plant (BOP) systems were developed. The BOP costs included the reactorto-refinery heat transport system. All cost data were escalated to July 1, 1974. Table 19 presents an overall cost summary for the three cases.

The costs for the refinery process heat systems were further analyzed to determine the value of energy at various points in the process. The results of this analysis are shown in schematic form in Fig. 15 for the single reactor configuration and in Fig. 16 for the dual reactor configuration with steam generated at the refinery. This analysis was performed for a fixed change rate (FCR) of $15 \%$, an electric power selling price of $15 \mathrm{mils} / \mathrm{kWhr}$, a fuel oil cost of $\$ 2 / 10^{6} \mathrm{Btu}$, and a nuclear fuel cost of $\$ 0.42 / 10^{6} \mathrm{Btu}$.

Results for the single reactor configuration indicate that the refinery heat from the nuclear plant alone has a value of $\$ 1.57 / 10^{6} \mathrm{Btu}$, of which the nuclear reactor and fuel account for $\$ 1.30 / 10^{6} \mathrm{Btu}$; intermediate heat transport equipment accounts for the balance. The value 
Table 18. Heat transport fluid piping system cost data $\left(\$ \times 10^{6}\right)$

\begin{tabular}{|c|c|c|c|c|c|c|c|}
\hline Item & Helium & Hydrogen & Nitrogen & $\begin{array}{l}\text { Carbon } \\
\text { Dioxide }\end{array}$ & Steạm & HTS & $\mathrm{NaK}$ \\
\hline Supply piping & 55.379 & 39.496 & 67.386 & 55.985 & 48.973 & 6.053 & 14.415 \\
\hline $\begin{array}{l}\text { Return piping } \\
\quad \text { (including insulation) }\end{array}$ & 28.883 & 18.044 & 32.939 & 26.180 & 23.908 & 2.152 & 2.607 \\
\hline Pumps or circulators & 21.663 & 13.115 & 24.476 & 16.041 & 14.388 & 0.387 & 2.945 \\
\hline İnentory & 0.865 & 0.047 & 0.027 & & 0.004 & 1.776 & 13.646 \\
\hline Heat loss & 2.311 & 1.773 & 2.693 & 2.595 & 1.983 & 0.601 & 0.783 \\
\hline $\begin{array}{l}\text { Unrecovered pump or circulator } \\
\text { power loss }\end{array}$ & 2.146 & 1.299 & 2.425 & 1.589 & 1.425 & 0.038 & 0.291 \\
\hline Total piping system cost & 111.247 & 73.774 & 129.946 & 102.390 & 90.681 & 11.007 & 34.687 \\
\hline Heat exchanger cost $\left(\$ 20 / f t^{2}\right)$ & 4.523 & 4.138 & 5.607 & 5.529 & 5.480 & 3.600 & 2.562 \\
\hline $\begin{array}{l}\text { Total heat transport } \\
\text { loop cost }\end{array}$ & 115.8 & 77.9 & 135.6 & 107.9 & 96.2 & 14.6 & 37.2 \\
\hline
\end{tabular}




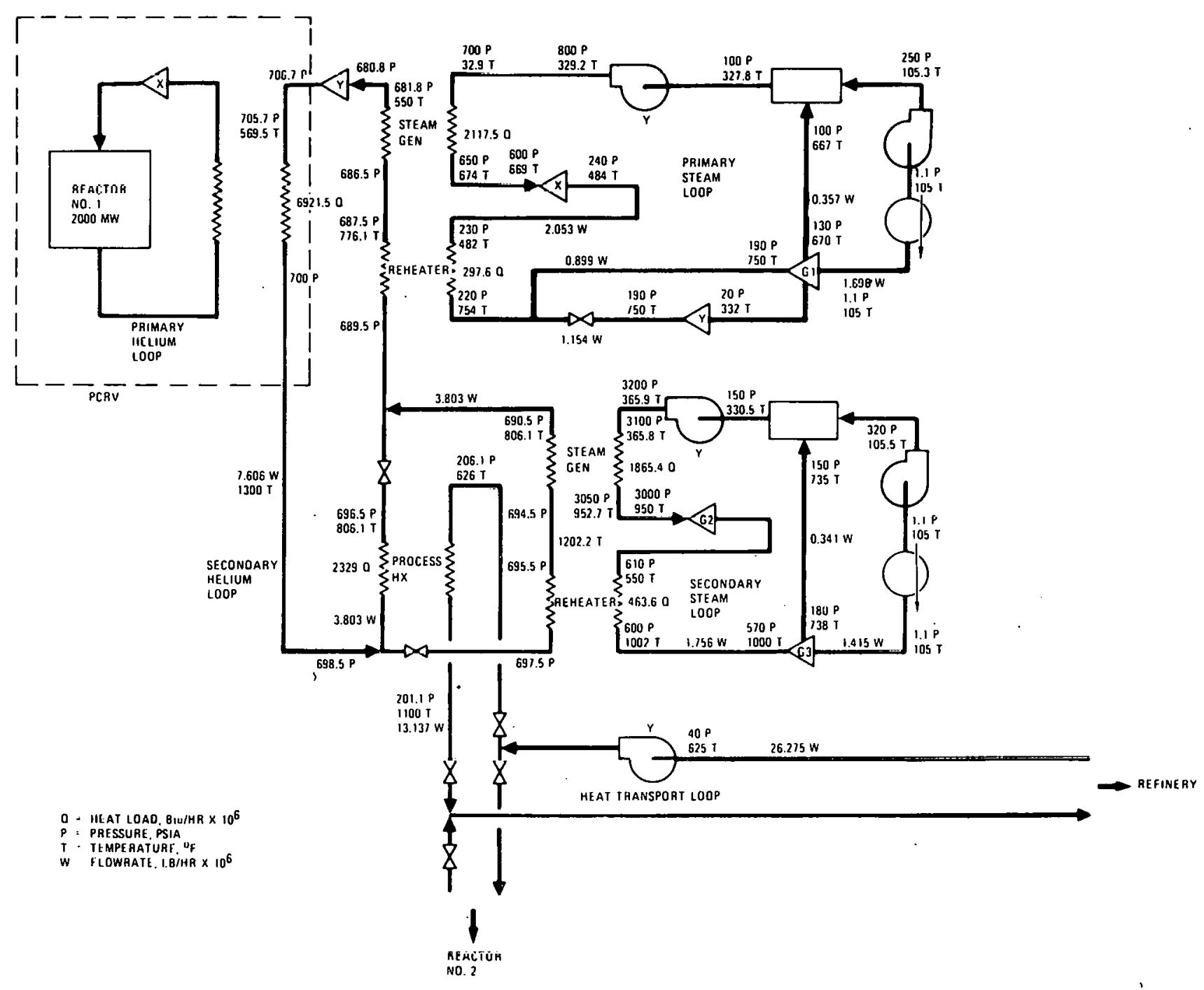

Fig. 12. Flow schematic of dual reactor configuration with steam generated at refinery.

of heat from the tossil heater is $\$ 4.55 / 10^{6} \mathrm{Btu}$, or nearly three times the cost of the nuclear heat. After accounting for heater efficiency, fossil fuel costs contribute $\$ 3.29 / 10^{\mathrm{C}} \mathrm{Btu}$. 'The high cost of fossil heat adds $\$ 0.67 / 10^{6}$ Btu to the refinery heat cost. The cost of producing electric power is not entirely recovered, and applying this loss to the cost of refinery heat adds an additional $\$ 0.21 / 10^{6} \mathrm{Btu}$. Electric power would sell on a break-even basis at about $20 \mathrm{mils} / \mathrm{kWhr}$.

Results for the dual reactor configuration show that the value of the refinery heat is slightly less than that for the single reactor 
ORNL-DWG 76-20624

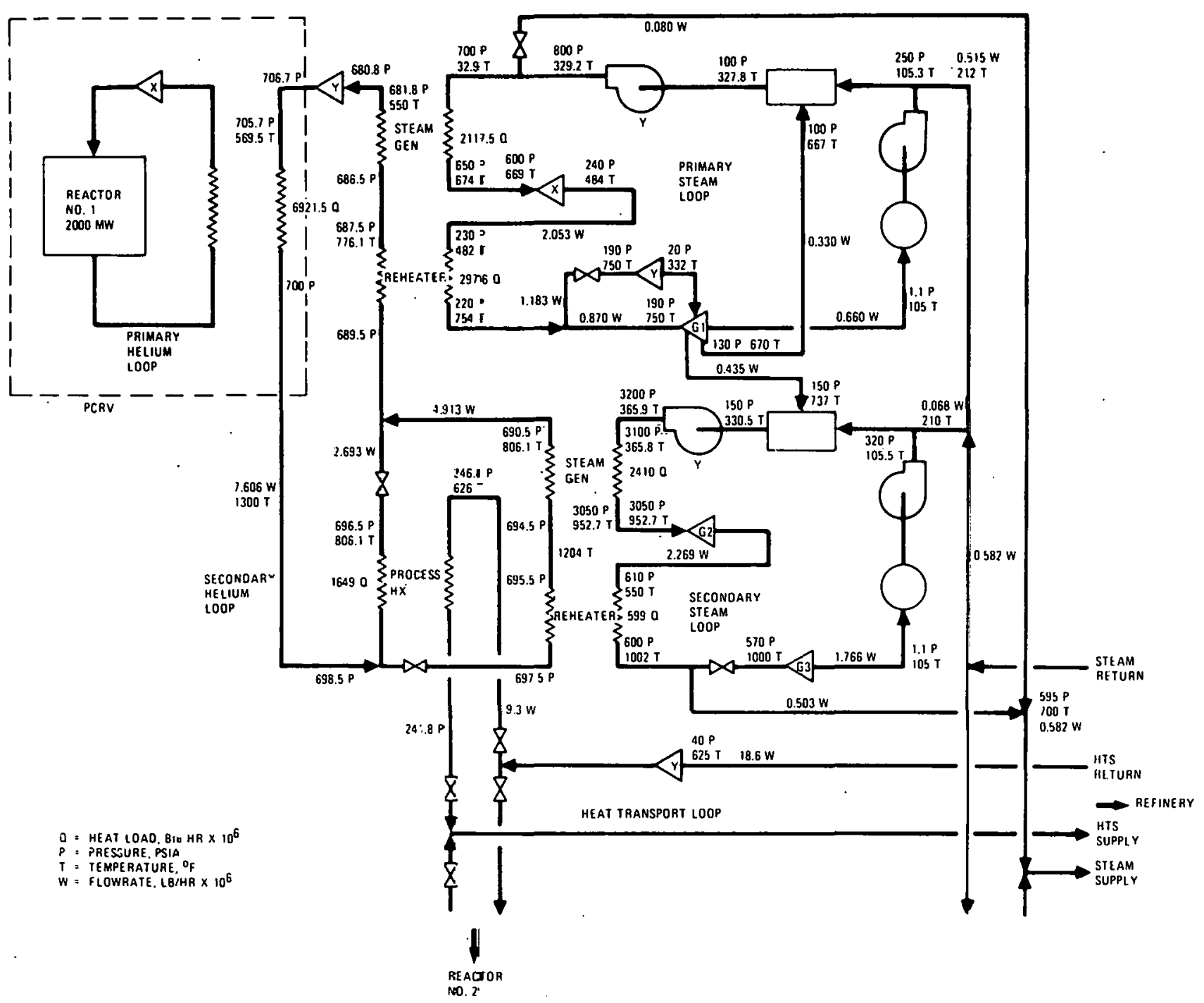

Fig. 13. Schematic of dual reactor configuration with steam generated at the reactor. 


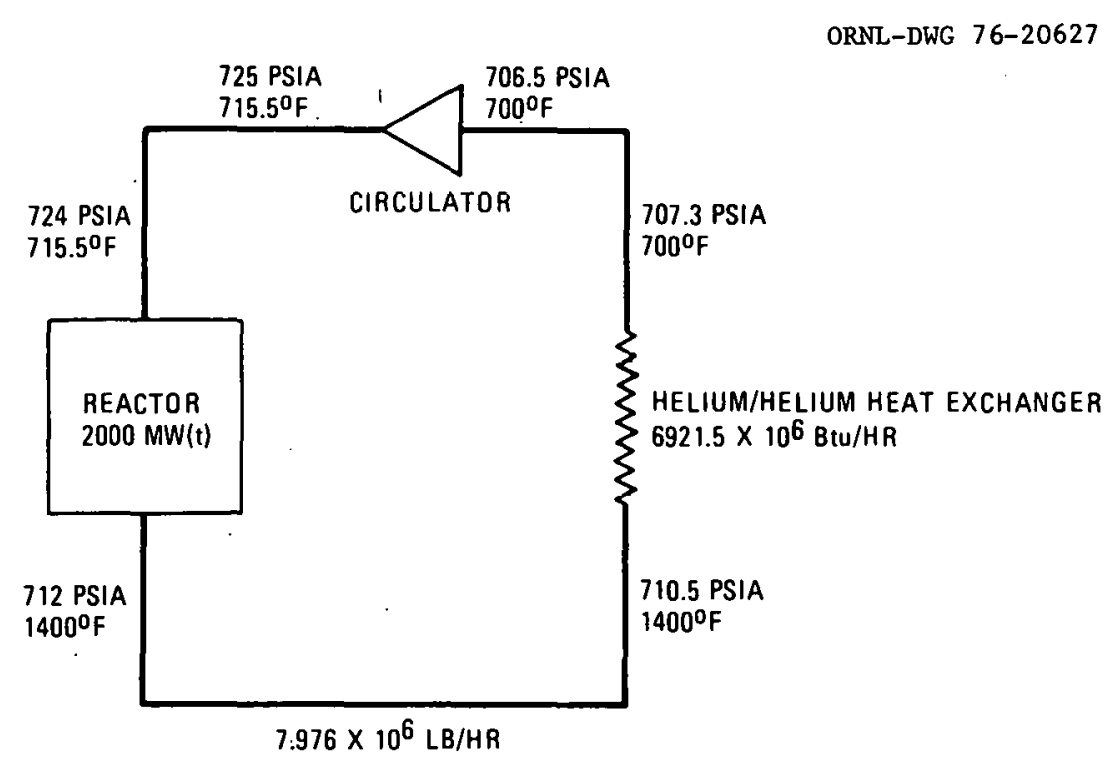

Fig. 14. Schematic of reactor cooling circuit (typical of all cycles).

configuration, owing principally to economies of scale. However, the cost of producing electric power is not fully recovered, and applying this loss to the refinery heat cost adds $\$ 0.48 / 10^{6}$ Btu. Electric power would sell on a break-even basis at about $18 \mathrm{mils} / \mathrm{kWhr}$.

Results clearly show that providing a backup heat source to meet $100 \%$ availability requirements for a refinery significantly increases the refinery heat cost. Considerable attention should be given to alternative configurations that could reduce the costs associated with backup systems or increase the revenue from the sale of electric power. The use of heat storage for either emergency refinery heat supply or supplying electric power for peaking are two attractive possibilities. Pursuing alternative schemes in this area appears to be one of the most promising approaches to reducing the refinery heat cost while maintaining the high reliability required for refinery process heat systems.

\subsection{Oil Shale and Tar Sands}

An evaluation of the application of the VHTR to oil shale and tar sands recovery and processing has been completed by the Resource Analysis and Management Group (RAMG) under contract with ORNL. 43

Tar sand is sand saturated with highly viscous hydrocarbons. The highly viscous hydrocarbon is not recoverable from its natural state by conventional oil production methods. Mining or in situ recovery with some new form of processing must be used to produce the tar sand hydrocarbon resource. 
Table 19. Overall cost sumary

\begin{tabular}{|c|c|c|c|}
\hline Configuration & $\begin{array}{l}\text { Single reactor } \\
\text { with fossil } \\
\text { fuel heater }\end{array}$ & $\begin{array}{l}\text { Dual reactors, } \\
\text { steam at refinery }\end{array}$ & $\begin{array}{l}\text { Dual reactors, } \\
\text { steam at reactor }\end{array}$ \\
\hline \multicolumn{4}{|l|}{ Capital costs $(\$)$} \\
\hline NSS & $105,072,000$ & $202,335,000$ & $202,335,000$ \\
\hline BOP & $284,100,500$ & $472,239,200$ & $478,533,400$ \\
\hline Interest during construction ( $17 \%$ total) & $66,159,100$ & $114,677,600$ & $115,747,700$ \\
\hline Total & $455,331,600$ & $789,251,800$ & $796,616,100$ \\
\hline \multicolumn{4}{|l|}{ Annual costs (\$/year) } \\
\hline Capital at $15 \%$ FCR & $68,299,700$ & $118,387,800$ & $119,492,400$ \\
\hline Capital at $25 \%$ FCR & $113,832,900$ & $197,310,300$ & $199,154,000$ \\
\hline Operation and maintenance & $2,757,000$ & $4,583,000$ & $4,583,000$ \\
\hline Nuclear fuel at $\$ 0.42 / 10^{6} \mathrm{Btu}$ & $22,607,400$ & $45,214,800$ & $45,214,800$ \\
\hline $\begin{array}{l}\text { Income from sale of electrical power at } \\
\$ 0.15 / \mathrm{kWhr}\end{array}$ & $-25,854,500$ & $-87,105,100$ & $-91,288,100$ \\
\hline Fossil fuel (oil) at $\$ 2 / 10^{6} \mathrm{Btu}$ & $29,193,300$ & & \\
\hline Total at $0.15 \mathrm{FCR}$ & $97,002,900$ & $81,080,500$ & $78,002,100$ \\
\hline Total at 0.25 FCR & $142,536,100$ & $160,003,000$ & $157,663,700$ \\
\hline \multicolumn{4}{|l|}{ Annual cost $/ 10^{6}$ Btu to refinery $\left(\$ / 10^{6} \mathrm{Btu}\right)$} \\
\hline $0.15 \mathrm{FCR}$ & 2.45 & 1.99 & 1.91 \\
\hline $0.25 \mathrm{FCR}$ & 3.60 & 3.92 & 3.86 \\
\hline
\end{tabular}

$a_{\text {Nuclear plant capacity factor }}=0.90$; fossil fuel heater operates at $25 \%$ capacity during $90 \%$ of the year and at $100 \%$ capacity during $10 \%$ of the year. 


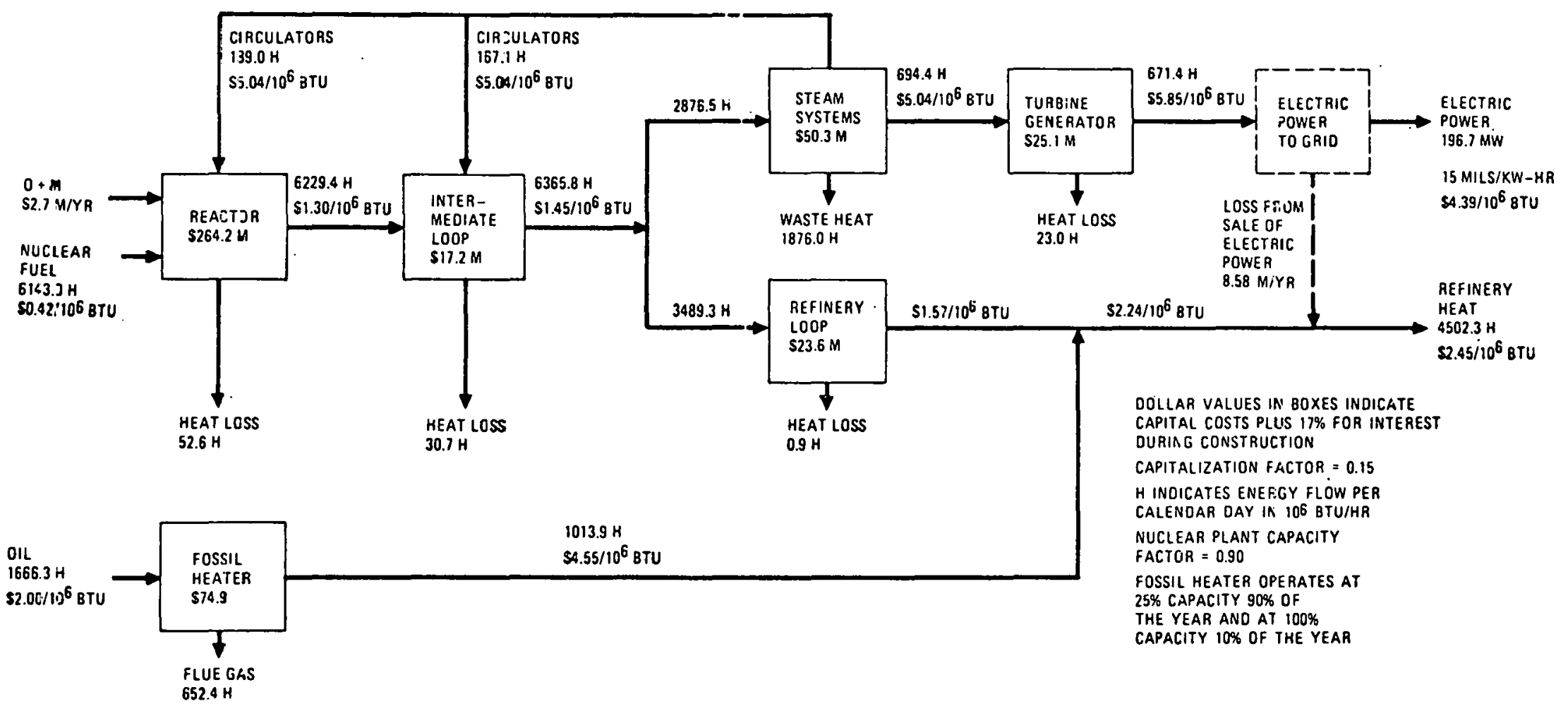

Fig. 15. Dollar flow through process heat plant - single reactor configuration. 
ORNL-DWG 76-20625

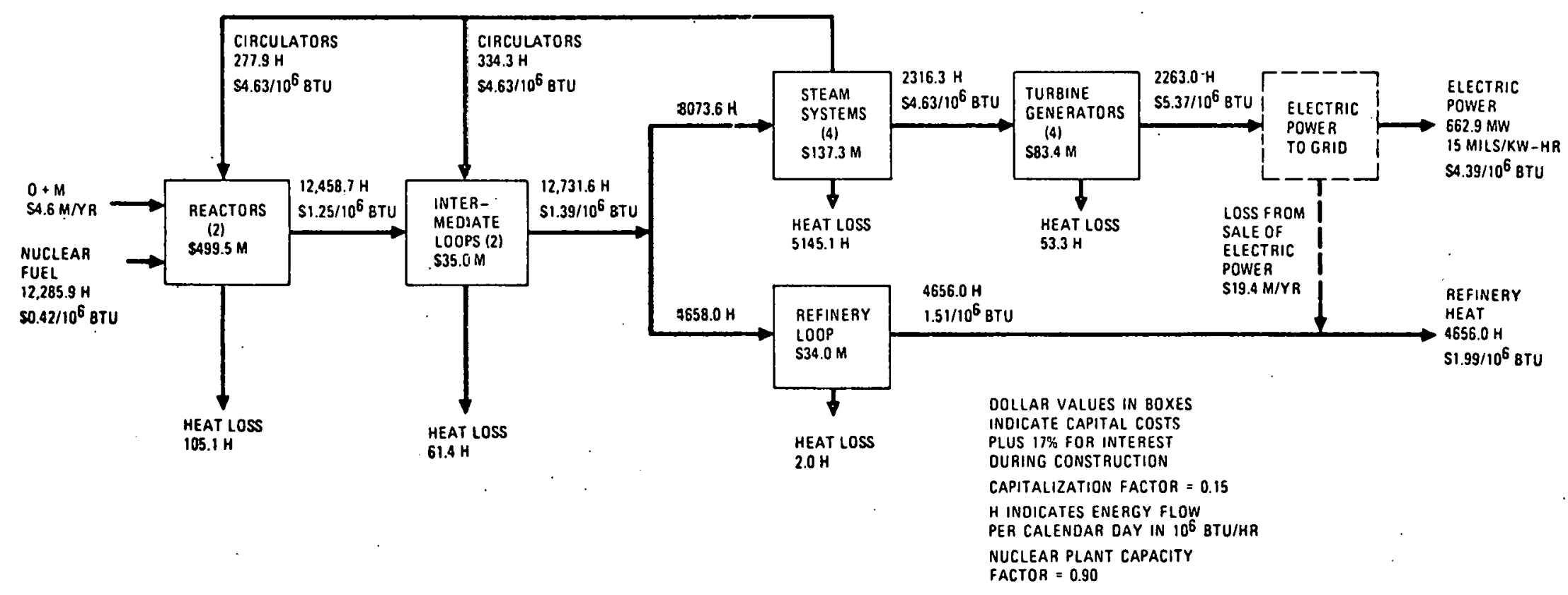

Fig. 16. Dollar flow through process heat plant, dual reactor configuration, with steam generated at refinery. 
Major tar sand deposits are in Alberta, Canada (Athabasca, Cold Lake, Wabaska, Peace River, and Buffalo Head Hills), Venezuela (Orinoco Tar Belt), Colombia, and the United States. The locations of tar sand in sufficient quantities to supply at least one $100,000 \mathrm{bbl} / \mathrm{day}$ production facility for 30 years are shown in Table 20 .

Table 20. Tar sand resources

\begin{tabular}{lc}
\hline \multicolumn{1}{c}{ Location } & Resource base (billion bbl) \\
\hline \multicolumn{1}{c}{ Western Hemisphere (exclusing U.S.) } \\
Athabasca Tar Sand, Canada & 626 \\
Cold Lake, Canada & 165 \\
Wabaska, Canada & 53 \\
Peace River, Canada & 50 \\
Buffalo Head Hills, Canada & 1 \\
Guanoco and Orinoco, Venezuela & 600 \\
Llanos, Colombia & 1000 \\
Total & $\frac{2495}{}$
\end{tabular}

\section{United States}

Tar Sand Triangle, Utah

$$
\begin{array}{r}
10.0 \text { to } 18.1 \\
3.7 \text { to } 3.8 \\
2.0 \text { to } 3.0 \\
3.0 \text { to } 3.8 \\
\hline 18.7 \text { to } 28.7
\end{array}
$$$$
\text { P.R. Spring, Utah }
$$$$
\text { Sunnyside, Utah }
$$$$
\text { others }
$$

Total

The application of VHTRs to tar sand recovery and processing does not seem especially promising since the domestic resource base is only about one-seventieth that of oil shale. Factors likely to deter significant production of syncrude from domestic tar sands include:

1. Keserves of domestic coal and oil shale are much larger, as are their oil yields.

2. The Utah sands are believed to be harder (more consolidated) and therefore more difficult to use than those of Alberta. 
3. Average overburdens are thicker in Utah than in Alberta, which sharply limits large-scale surface mining and would require the successful development of in situ recovery methods usable on a commercial scale. However, estimated bitumen recovery efficiencies by in situ techniques such as steam-emulsion drive or "fireflooding" are significantly lower than those for surface extraction.

4. Most of the Utah deposits underlie Federal lands and appropriate leasing arrangements would be necessary. In addition, public-use proposals have already been made for much of the subject su=face area.

5. Water supplies may be insufficient for significant exploitation.

The role of syncrude from domestic tar sands in the future U.S. energy supply seems at best, a minor one.

The principal oil shale resources in the United States are located in the Green River Formation (Colorado), in Utah, Wyoming, and in Marine Shale deposits in Alaska. A summary of the oil shale resources is presented in Table 21 .

Table 21. Shale oil resources

\begin{tabular}{lc}
\hline \multicolumn{1}{c}{ United States } & Resource \\
\hline Green River Formation, Colorado & 1200 \\
Marine Shale, Alaska & 250 \\
Shale associated with coal & 50 \\
Other shale deposits & 500 \\
$\quad$ Total & 2000 \\
\hline
\end{tabular}

Six different processing concepts were evaluated both with and without the use of the VHTR. The U.S. Bureau of Mines' gas combustion process, with its underground mining operations, was used for a relative comparison of the advantages and disadvantages of the use of a VHTR to process oil shale. The Great Canadian oil sands process was taken as a representative scheme to make a relative comparison with the VHTR modified process for aboveground conversion of tar sand bitumen to a syncrude. The Shell steam-injection in situ tar sand process was taken as a basis for comparison in the use of the VHTR for in situ recovery of tar sand bitumen. Where possible, the primary refining step used was the Hydrocarbon Research Incorporated $\mathrm{H}-\mathrm{Oil}$ hydrogenation unit.

The evaluation of use of VHTR nuclear process heat for tar sand and oil shale recovery and upgrading indicated the following: 
1. Processing plants are estimated to be built, at least initially, in parallel trains in size increments of $50,000 \mathrm{bbl} /$ day.

2. No substantial capital or operating cost savings are projected for process plant sizes exceeding 100,000 barrels per calendar day.

3. The estimated plant capacity at a single site ranges from 100 to 150,000 barrels per calendar day.

4. The VHTR, if it is to be used as an energy source for tar sand and oil shale recovery and upgrading, should have a $90 \%$ availability.

5. Preliminary evaluations indicate that for oil shale recovery and processing, a VHTR with an output significantly less than 3000 $\mathrm{MW}(\mathrm{t})$ may be more attractive.

6. The 3000-MW(t) VHTR coupled with the $100,000 \mathrm{bbl} /$ day tar sand recovery plant using in situ injection is the best match of the processes considered.

7. One or two in situ, $100,000 \mathrm{bbl} /$ day tar sand recovery and upgrading operations could be powered by 3000-MW( $t$ ) VHTRs by the year 2000 in Canada and possibly in Venezuela. None are likely in the United States.

8. The estimate of oil shale plant capacity by the year 2000 is 300,000 to $500,000 \mathrm{bbl} / \mathrm{day}$, which would lead to a projection of no more than onc VHTR of 2000- to $3000-\mathrm{MW}(t)$ size as a potential market.

9. Estimated benefits of nuclear process heat applications of a VHTR are a $24 \%$ to $50 \%$ better utilization of the in-place resource, with an attendant lessening of the environmental impact of resource production and about $20 \%$ lower water requirement.

The relative cost of oil shale recovery developed in the RAMG report 43 indicates that use of the VHTR would increase the cost of the syncrude in comparison with the fossil base process by about $20 \%$. This appears to be primarily the result of an optimistic estimate of the cost of mining, processing; disposal, etc., which favors the conventional process.

On a more comparable basis, as developed in Table 22 , the cost of syncrude from oil shale using a VHTR appears to be essentially competitive with the conventional process. Even so, the market potential in oil shale recovery and processing is not projected to be significant. 
Table 22. Oil shale recovery

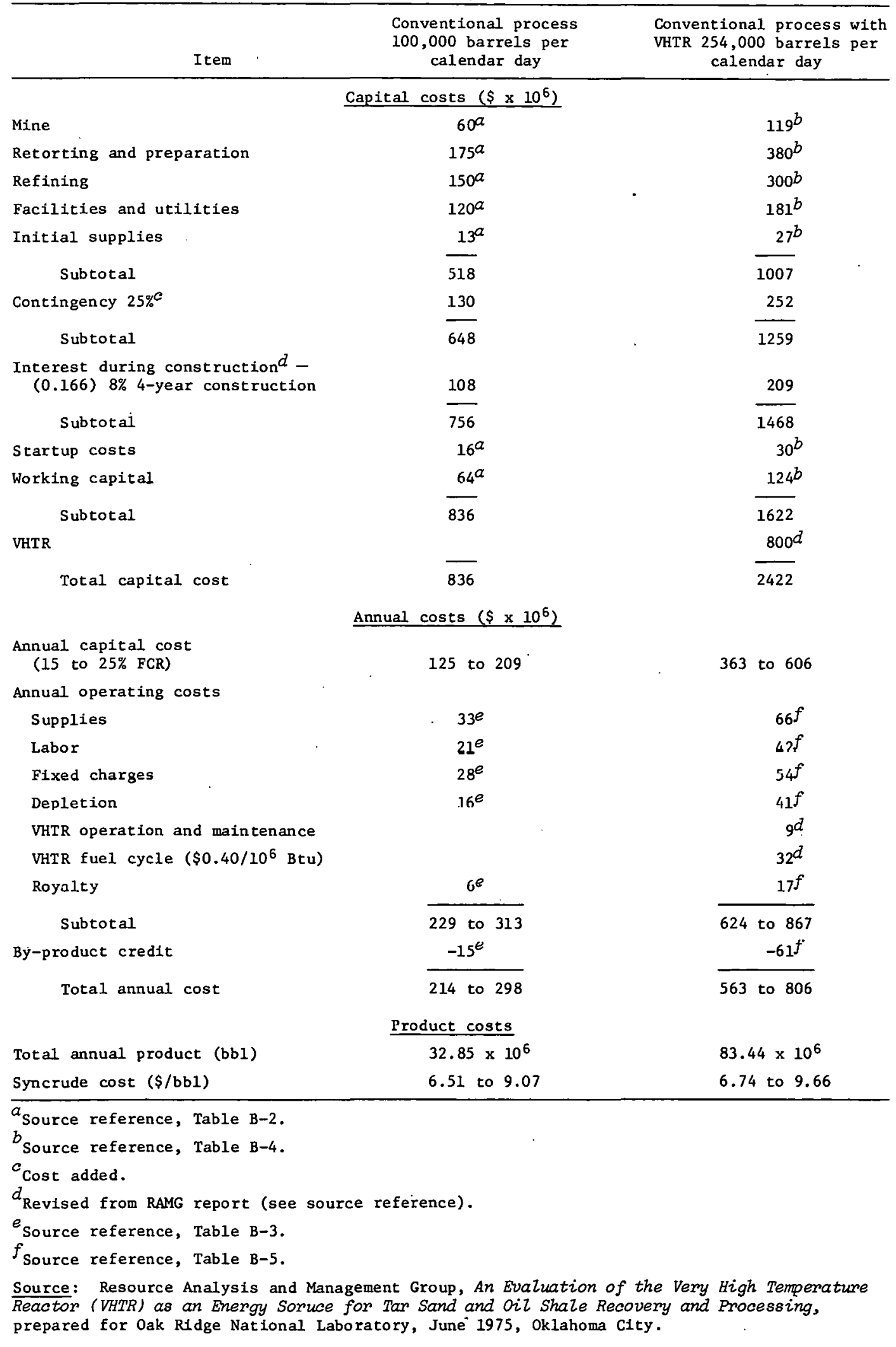




\section{ENERGY STORAGE, TRANSPORT, AND PEAKING POWER APPLICATIONS}

\subsection{Summary}

\section{1 .1 Introduction}

The nuclear reactor is a source of primary energy which has been restricted to the production of base-load electricity. In an effort to expand the nuclear reactor's contribution to the energy market, several systems have been investigated which allow nuclear energy to be transported directly or stored for intermediate load and peaking power.

If nuclear power is to capture a major portion of the energy market, then it must provide the user with a significant amount of thermal energy. Transportation of electricity for use as thermal energy is inherently a very inefficient means of energy transport. Therefore, to reduce this inefficiency, the energy should either be generated onsite, or an alternate system of transportation must be sought. Several investigators propose using the reversible steam-methane reaction in a chemical heat pipe as a transmission technique for nuclear process heat. 44,45 This system could attain an efficiency of $70 \%$ to $80 \%$ and be economically competitlve with conventional electrical transmission.

Electric demand levels are normally separated into three broad areas: base load, intermediate load, and peak load. The base load is normally provided by the newer fossil-fuel, nuclear, and hydroelectric plants. Intermediate- and peak-load power demand are currently met (1) by generation in fossil-fueled (oil- and coal-fired) steam plants, (2) by hydropower or pumped storage, and (3) in gas turbines with highquality, expensive fuels. Except for pumped storage, which is relatively inefficient and is limited to very few sites, there is no economic commercial system for use of nuclear energy to meet peak and/or intermediate electrical load. The combination of the VHTR and chemical or hightemperature thermal energy storage should lead to a competitive source of intermediate load and peaking power.

The power load of an electrical utility grid fluctuates by as much as a factor of 2 on a daily basis. Figure 17 presents a typical weekly load curve for a large midwestern utility. ${ }^{46}$ The objective of the VHTR peaking power system is to meet the daily peak demand of the grid (or a portion of that demand).

\subsubsection{Potential market}

The Project Independence-MS 47 scenario, or ERDA "moderate/1ow" forecasts of electric power growth, has been chosen as a basis for estlmating the potential market for VHTRs in the electric power industry. Results of our projection are given in Table 23. This table was deve1oped according. to the following reasoning: an ERDA report (ERDA-48) estimated HTGR penetration into the electric power market at about $3.9 \times 10^{15} \mathrm{Btu} /$ year by the year 2000.48 This corresponds to roughly $10 \%$ of the nuclear base load. It was assumed that VHTR intermediate-load and peaking plants could capture about one-third of the market for GCRs 


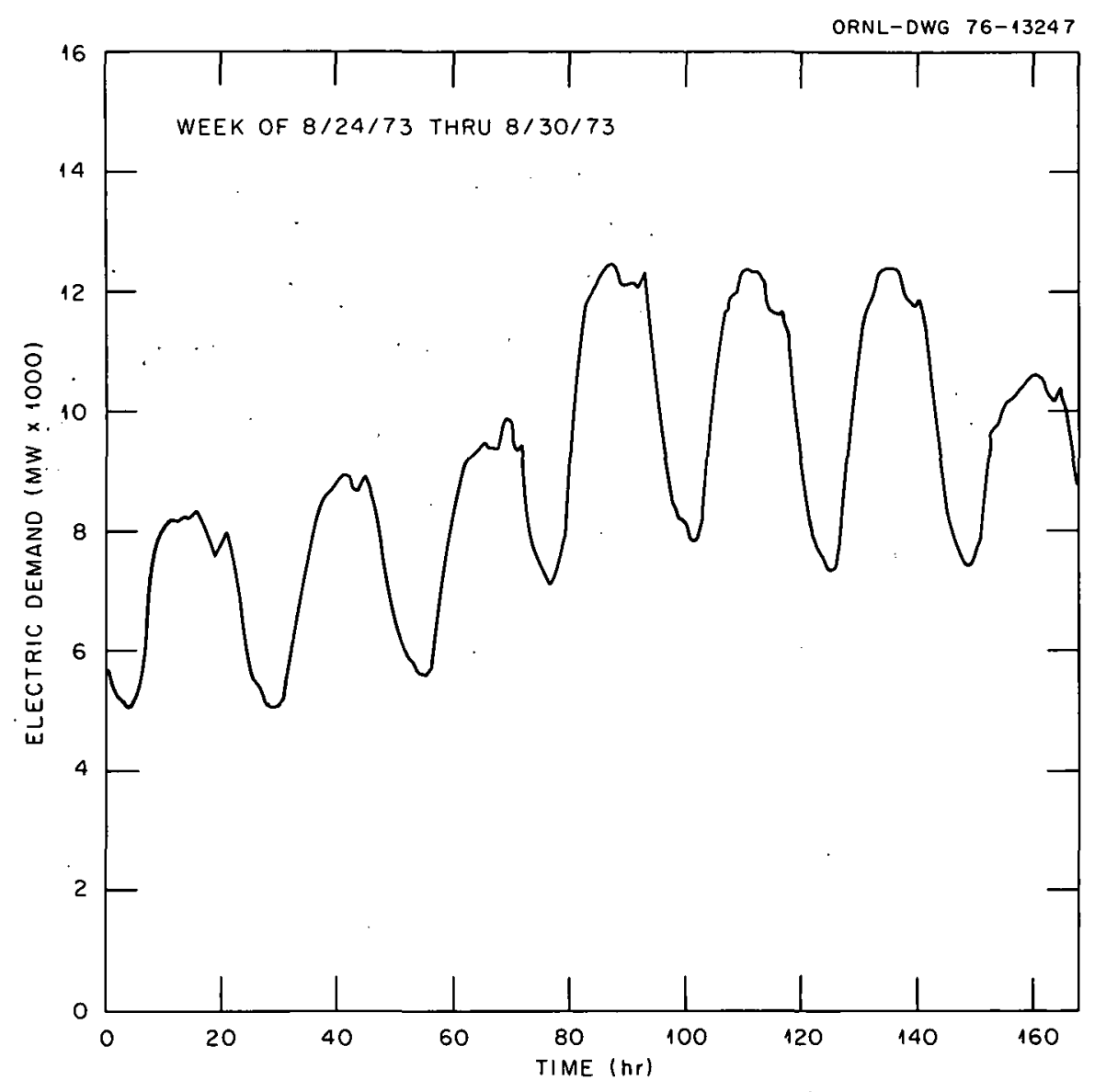

Fig. 17. Weekly load for large midwestern utility.

by the year 2000. Each intermediate-load plant was assumed (for this table) to have a nominal peak rating equal to the $M W(t)$ rating of the nuclear island. The period 2000 to 2030 was extrapolated from the pre-2000 predictions.

The load curve, Fig. 17, implies that at least one-third of all generating capacity is dedicated to intermediate and peak load. Our market projections conservatively assume that only about $20 \%$ of the market is served by VHTR peaking plants in the year 2000 .

\section{1 .3 Conclusions}

Figures 18, 19, and 20 are cost comparisons of EVA-ADAM storage, HTS storage, and three conventional power systems - gas turbines and coal- and oil-fired steam systems. The economic cost basis for the three conventional systems is presented in Table 24. 
Table 23. Potential penetration of HTGR, GT-HTGR, and VHTR intermediate-load and peaking plants into the electric utility market

\begin{tabular}{|c|c|c|c|c|c|c|}
\hline Year & $\begin{array}{l}\text { Total } \\
\text { electrical } \\
\text { capacity } \\
{[\text { GW }(e)]}\end{array}$ & $\begin{array}{l}\text { Total } \\
\text { nuclear } \\
\text { capacity } \\
{[\mathrm{GW}(\mathrm{e})]}\end{array}$ & $\begin{array}{l}\text { Total } \\
\text { HTGR } \\
+ \\
\text { GT-HTGR } \\
{[\text { GW }(e)]}\end{array}$ & $\begin{array}{c}\text { Equivalent number } \\
\text { of } 3000-\mathrm{MW}(\mathrm{t}) \\
{[1000 \mathrm{MW}(\mathrm{e})]} \\
\text { HTGR + GT-HTGR } \\
\text { units }\end{array}$ & $\begin{array}{l}\text { Number of } \\
\text { intermediate-load } \\
\text { and peaking VHTR } \\
3000-\mathrm{MW}(t) \text { units }\end{array}$ & $\begin{array}{l}\text { Total VHTR } \\
\text { intermediate } \\
\text { and peaking } \\
\text { capacity } \\
\text { [GW(e)] }\end{array}$ \\
\hline 1973 & 436 & 18.4 & 0 & 0 & 0 & 0 \\
\hline 1985 & 800 & 185 & 0.3 & 0 & 0 & $\dot{0}$ \\
\hline 1990 & 1040 & 340 & 5 & 5 & 1 & 3 \\
\hline 1995 & 1350 & 545 & 30 & 30 & 5 & 15 \\
\hline 2000 & 1750 & 800 & 80 & 80 & 27 & 80 \\
\hline 2030 & 3500 & 2500 & 250 & 250 & 120 & 360 \\
\hline
\end{tabular}

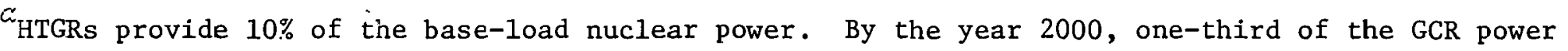
plant capacity is VHTR peaking plants. This represents only about $20 \%$ of the total peaking and intermediate-load capacity. 


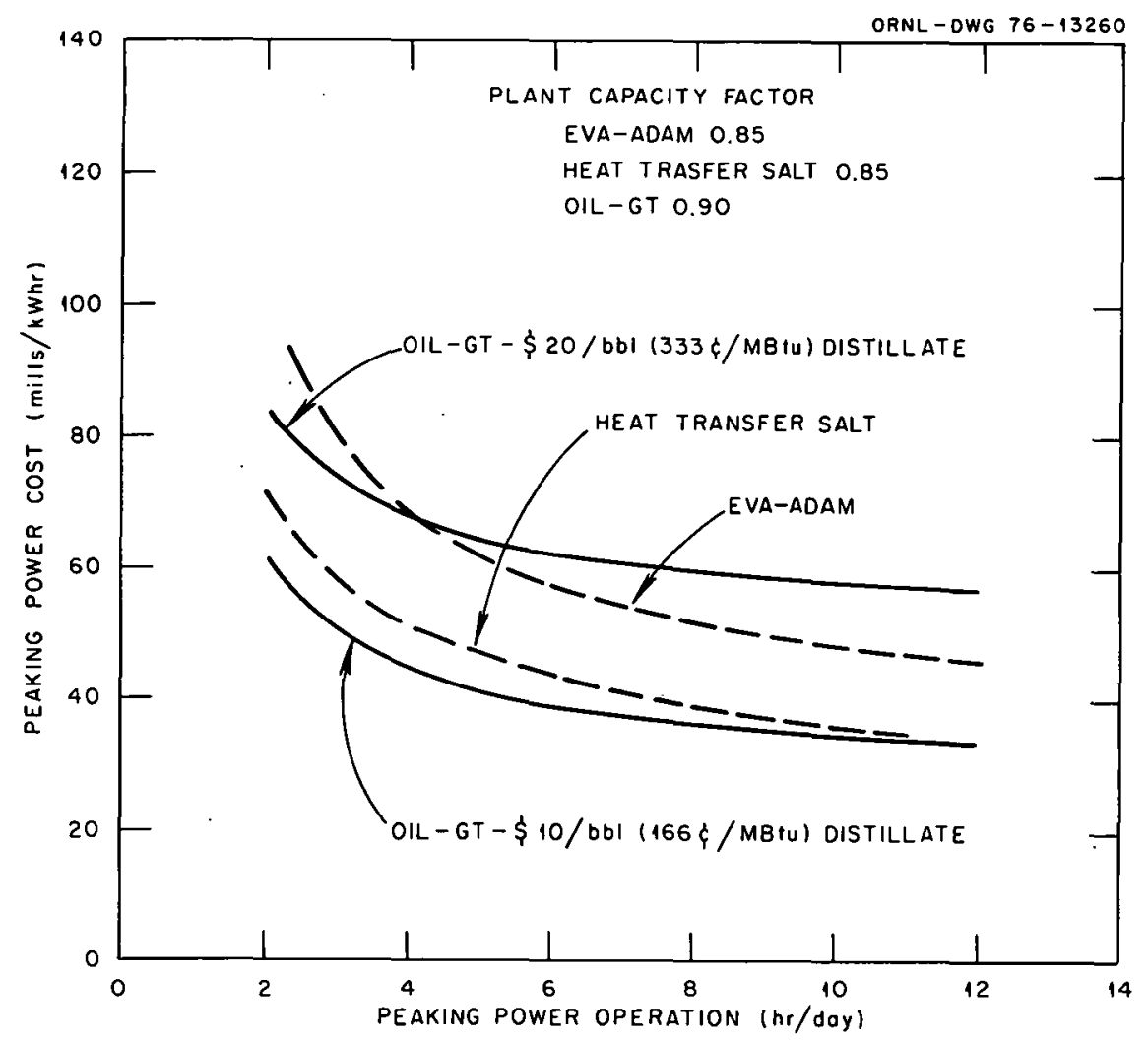

F1g. 18. Cost comparison between storage system and gas turbine power plants.

Although this is a preliminary analysis, it appears that the EVA-ADAM peaking system will be competitive only if fuel prices rise.considerably above their current level. As can be seen in Fig. 18, the cost of a gas turbine system is not a strong function of the period of operation but is very sensitive to fuel costs. Compared to a gas turbine system, EVA-ADAM would be competitive at higher fuel prices only if it acted as an intermediate power producer used 6 to $12 \mathrm{hr} /$ day. However, it can be inferred from Figs. 19 and 20 that in this range of operation, fossilfired steam plants would be more economical even at higher fuel costs.

The HTS system appears to be a very attractive alternative to present gas turbine peaking systems. It can be seen in Fig. 18 that the HTS system is competitive with the gas turbine system even at the lower range of fuel prices. This system is more economical than EVA-ADAM because it has a lower capital investment per kilowatt of peaking power; but, as the EVA-ADAM system, it has a low operating cost, so it will become even more attractive as the price of fossil fuels rise. Because of its low operating costs, the HTS storage system has the additional advantage of . being competitive with the steam cycles for production of intermediateload power. Figures 19 and 20 show that this system is competitive with both the oil- and coal-fired systems at the lower fuel prices throughout the operating range. 


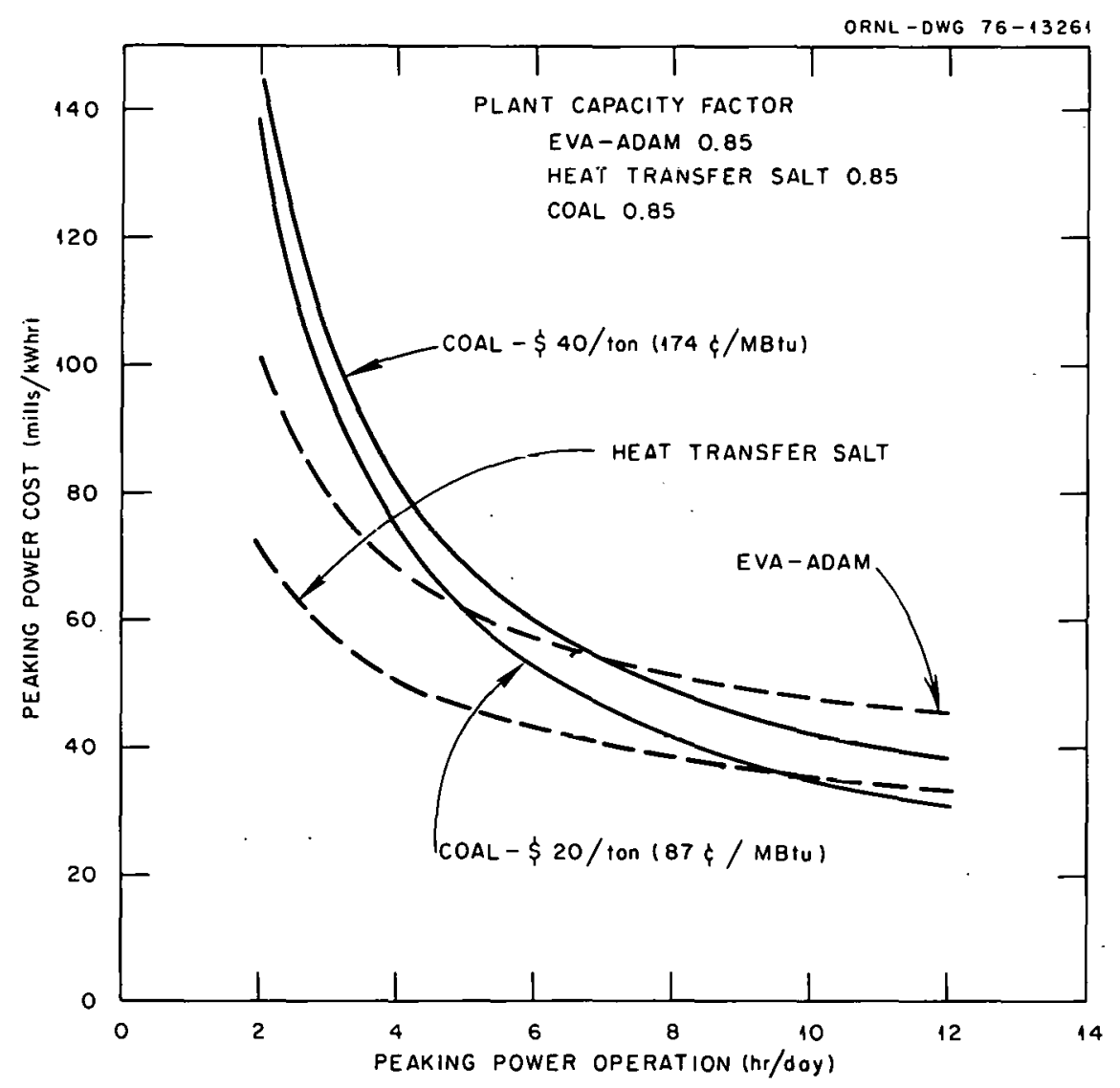

Fig. 19. Cost comparison between storage systems and coal-fired power plants.

The VHTR peaking power scheme would reduce the electric power industry's demand for high-quality fuels which have alternative uses for transportation and home heating and which provide a mechanism whereby nuclear energy could be effectively used to meet intermediate peak power demand.

In comparison with other nonfossil energy transportation systems in the production of process steam (Table 25 and Fig. 21), the EVA-ADAM transport system is competitive for intermediate distances (less than 300 miles). However, within the present price range of coal, EVA-ADAM is not competitive with the nuclear-fossil hybrid transport systems. It is clear that EVA-ADAM is a future concept that will not be a viable alternative until fossil-fuel prices rise substantially above their current leve1. However, in a carbon-poor economy, this system appears to be a good choice for intermediate-distance energy transport. 


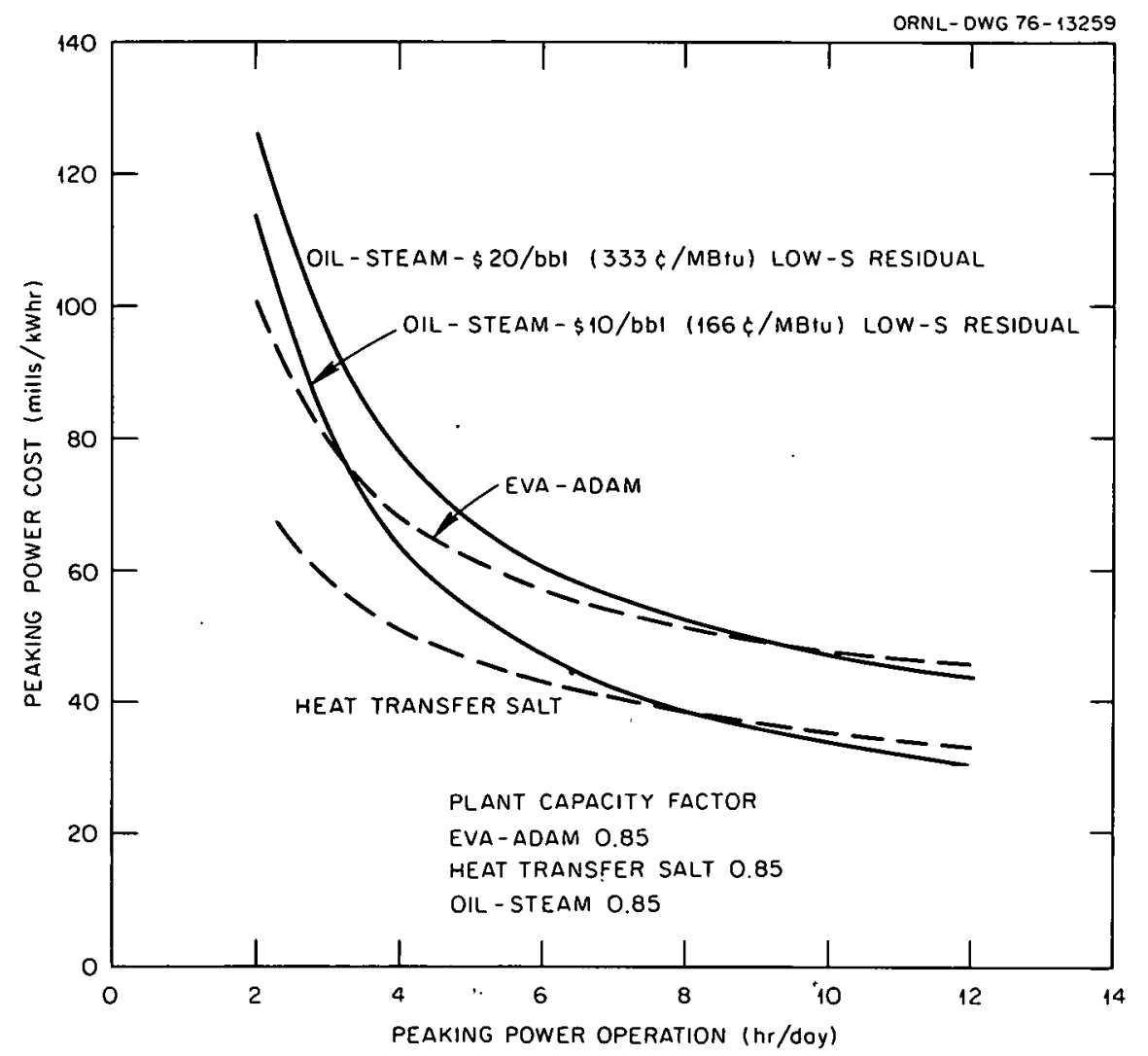

Fig. 20. Cost comparison between storage systems and oil-fired power plants.

\subsection{EVA-ADAM}

In recent years interest in new techniques for the storage and transmission of energy has increased substantially, primarily because of the higher cost of energy and the need for effective transmission and storage systems. Of the many storage and transmission techniques available, the reversible chemical reaction appears to be a plausible and attractive alternative and a mechanism by which nuclear power may provide long-distance energy for process and space heat; it is certainly applicable to VHTR development. There are many reactions that are adaptable to this type of system, and some of these are listed in Table 26.

The steam-methane reaction is one that is highly endothermic and displays the reversibility necessary for a chemical storage and transmission system. Steam-methane reforming is a common practice in the petrochemical industry, and the reverse methanation process has been in use for many years in the production of ammonia. Also, methanation is receiving substantial development effort for the production of pipeline gas from coal. Familiarity with this reaction makes it a practical 
Table 24. Cost summary for conventional peaking and intermediate-load systems $a, b$ [basis: $1000 \mathrm{MW}(\mathrm{e})$ ]

\begin{tabular}{|c|c|c|c|}
\hline Item & Coal-steam & 0il-steam & Oil-gas turbine \\
\hline Total capital investment $\left(10^{6} \$\right)$ & 485 & 372 & $1 \dot{40}$ \\
\hline $\begin{array}{l}\text { Annual capital cost }(F C R=0.15) \\
\quad\left(10^{6} \text { \$/year }\right)\end{array}$ & 72.8 & 55.8 & 21 \\
\hline Fuel use ( $100 \%$ plant capacity factor) & $3.25 \times 10^{6}$ tons/year & $11.89 \times 10^{6}$ bbl/ye.ar & $20.53 \times 10^{5} \mathrm{bbl} /$ year \\
\hline Fuel cost $\left(10^{6}\right.$ s/year $)$ & $3.25 \mathrm{FC}$ & $11.89 \mathrm{FP}$ & 20.53 FG \\
\hline \multicolumn{4}{|l|}{ Annial operating and maintenance cost } \\
\hline Fixed $\left(10^{6} \$ /\right.$ year $)$ & 7.1 & 5.6 & 0.8 \\
\hline Variable $\left(10^{6} \$ /\right.$ year $)$ & $16 \mathrm{~F}$ & $4.2 \mathrm{~F}$ & $36 \mathrm{~F}$ \\
\hline Total annual cost $\left(10^{6}\right.$ \$/year $)$ & $(79.9+16 \mathrm{~F}+3.25 \mathrm{FC})$ & $(61.4+4.2 \mathrm{~F}+11.89 \mathrm{FP})$ & $(21.8+36 \mathrm{~F}+20.5 \mathrm{FG})$ \\
\hline Annual power produced (kWhr/year) & $8.76 \times 10^{9} \mathrm{~F}$ & $8.76 \times 10^{9} \mathrm{~F}$ & $8.76 \times 10^{9} \mathrm{~F}$ \\
\hline Unit cost (mills/kWhr) & $9.12 / F+1.83+0.371 \mathrm{C}$ & $7.01 / F+0.478+1.36 \mathrm{P}$ & $2.49 / F+4.14+2.34 G$ \\
\hline
\end{tabular}

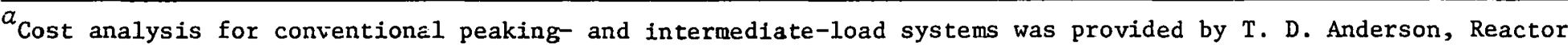
Division, ORNL.

${ }_{\text {Abbreviation key: }} \mathrm{F}=$ plant capacity factor; $\mathrm{C}=\$ /$ ton of coal; $\mathrm{P}=\$ / \mathrm{bbl}$ residual oil; $\mathrm{G}=\$ / \mathrm{bbl}$ distillate. 
Table 25. Cost sumnary for transportation systems for process steam production

\begin{tabular}{|c|c|c|c|c|}
\hline Cost item & $\mathrm{GA} / \mathrm{S} \& \mathrm{~N} \mathrm{H}_{2}$ & $\mathrm{GA} / \mathrm{S} \& \mathrm{~W} \mathrm{CH}_{4}$ & Westinghouse $\mathrm{H}_{2}$ & Electricity \\
\hline Coal cost, $\$ / 10^{6} \mathrm{Btu}$ & 1.00 & 1.00 & & \\
\hline Nuclear cost, $\$ / 10^{6} \mathrm{Btu}$ & 0.45 & 0.45 & 0.45 & 0.45 \\
\hline Production cost, $\$ / 10^{6} \mathrm{Btu}$ & $3.20^{\alpha}$ & $2.58^{a}$ & 4.78 to $5.87^{\alpha}$ & $5.80^{b}$ \\
\hline Transport cost, $\$ / 10^{6} \mathrm{Btu} / 100 \mathrm{mile}$ & $0.11^{b}$ & $0.033^{c}$ & $0.11^{c}$ & $0.47^{d}$ \\
\hline Steam conversion, $\$ / 10^{6} \mathrm{Btu}$ & $0.52^{e}$ & $0.31^{e}$ & $0.52^{e}$ & $0.09^{e}$ \\
\hline Boiler efficiency, \% & 85 & 85 & 85 & 100 \\
\hline Steam cost, $\$ / 10^{6}$ Btu & $\begin{array}{l}4.37+0.13 / \\
100 \mathrm{nile}\end{array}$ & $\begin{array}{l}3.40+0.04 / \\
100 \mathrm{mile}\end{array}$ & $\begin{array}{l}6.22-7.50 \\
0.13 / 100 \mathrm{mile}\end{array}$ & $\begin{array}{l}5.89+0.47 / \\
100 \mathrm{mile}\end{array}$ \\
\hline \multicolumn{5}{|c|}{ 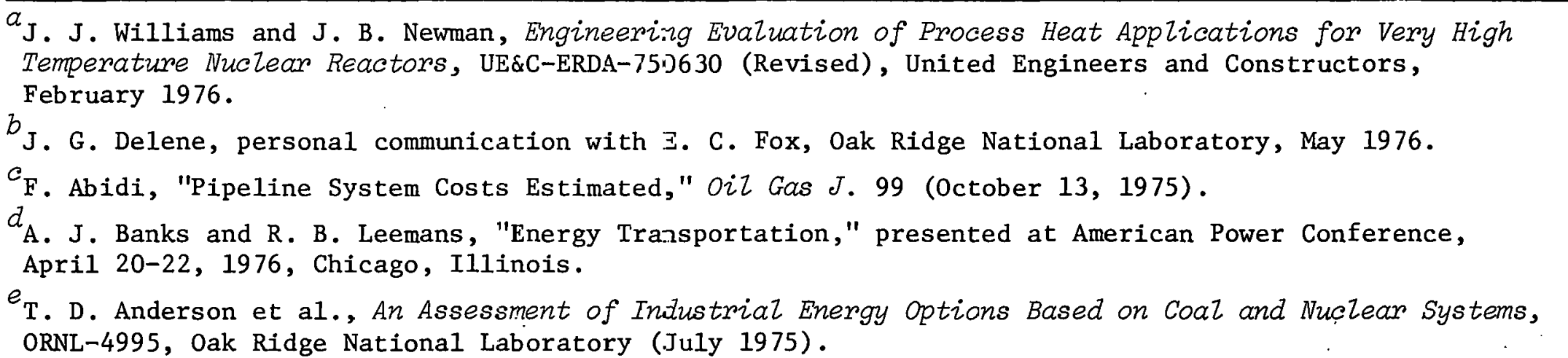 } \\
\hline
\end{tabular}




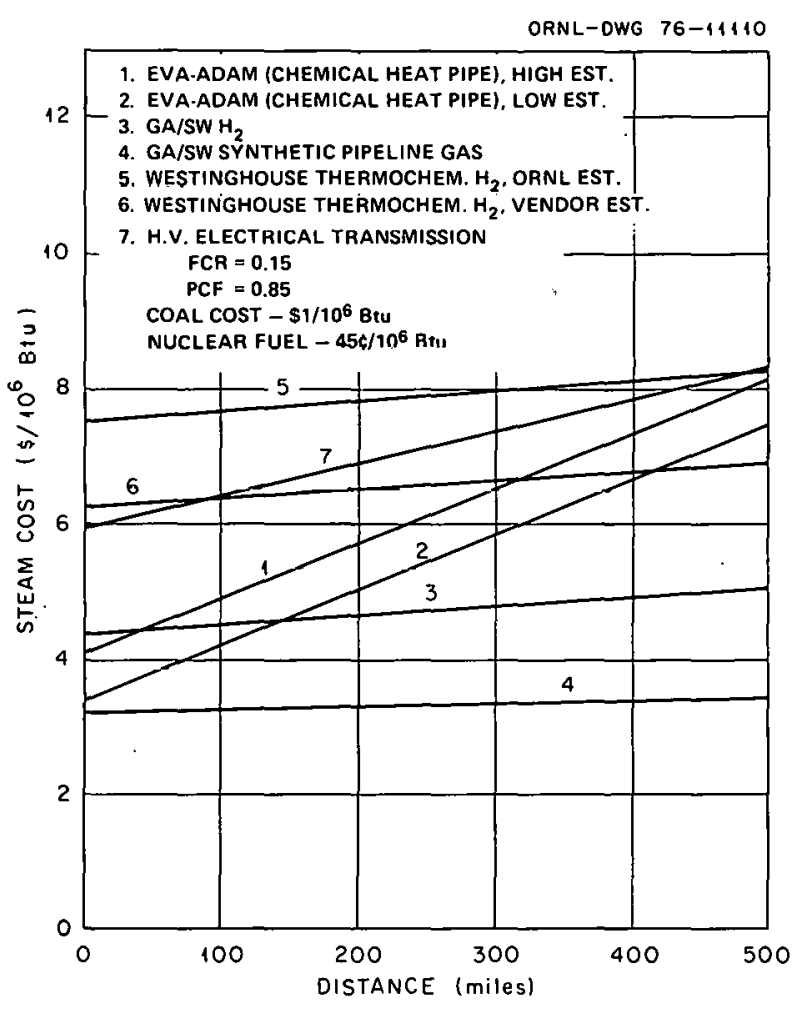

Fig. 21. Cost of chemical heat pipe and alternatives for the production of process steam.

choice and a prime candidate for an economic analysis of chemical energy storage and transmission techniques.

The nuclear steam-methane chemical heat pipe, commonly known as EVA-ADAM, was first developed in West Germany, at the Nuclear Research Facility in Jülich, 45 where significant research has been conducted with helium-heated steam-methane reformers. This system is based on the reversible steam-methane reaction:

$$
\mathrm{CH}_{4}+\mathrm{H}_{2} \mathrm{O} \uparrow=\mathrm{CO}+3 \mathrm{H}_{2}, \Delta \mathrm{H}=49 \mathrm{kcal} / \mathrm{mole} \text {. }
$$

Additionally, a subsequent reversible reaction always takes place:

$$
\mathrm{CO}+\mathrm{H}_{2} \mathrm{O} \uparrow=\mathrm{CO}_{2}+\mathrm{H}_{2}, \Delta \overline{\mathrm{H}}=9.9 \mathrm{kcal} / \mathrm{mole} .
$$

This reaction is commonly known as the water-gas shift reaction. Conceptually, this system is based on using the heat of reaction as the transport mechanism. During the reforming step, $49 \mathrm{kcal}$ are absorbed per gram-mole of methane reacted. The gas product is then stored or transported to a methanator where the heat is removed from the reverse reaction, which takes place at a lower temperature. The steam-methane reaction takes place uver a nickel catalyst at temperatures of $700^{\circ}$ to 
Table 26. Closed-cycle chemical reactions

\begin{tabular}{lcc}
\hline Reaction & $\begin{array}{c}\text { Approximate heat of } \\
\text { reaction } 25^{\circ} \mathrm{C}(\mathrm{kcal} / \mathrm{mole})\end{array}$ & $\begin{array}{c}\text { Temperature range } \\
\left({ }^{\circ} \mathrm{C}\right)\end{array}$ \\
\hline $\mathrm{CH}_{4}+\mathrm{H}_{2} \mathrm{O}=3 \mathrm{H}_{2}+\mathrm{CO}$ & 49 & $425-1000$ \\
$\mathrm{CH}_{4}+\mathrm{CO}_{2}=2 \mathrm{CO}+2 \mathrm{H}_{2}$ & 59 & $425-1000$ \\
$\mathrm{CO}+\mathrm{CL}_{2}=\mathrm{COCl}_{2}$ & 27 & $250-750$ \\
$\mathrm{C}_{6} \mathrm{H}_{6}+3 \mathrm{H}_{2}=\mathrm{C}_{6} \mathrm{H}_{12}$ & 50 & $250-450$ \\
$\mathrm{C}_{10} \mathrm{H}_{8}+6 \mathrm{H}_{2}=\mathrm{C}_{10} \mathrm{H}_{18}$ & 75 & $175-425$ \\
$\mathrm{C}_{7} \mathrm{H}_{8}+3 \mathrm{H}_{2}=\mathrm{C}_{7} \mathrm{H}_{24}$ & 51 & $175-425$ \\
$\mathrm{C}_{2} \mathrm{H}_{4}+\mathrm{HCl}=\mathrm{C}_{2} \mathrm{H}_{5} \mathrm{Cl}$ & 13 & $150-500$ \\
\hline
\end{tabular}

$900^{\circ} \mathrm{C}$; the higher temperatures favor equilibrium and reaction rate. The reverse methanation reaction takes place over a nickel catalyst at temperatures of $350^{\circ}$ to $450^{\circ} \mathrm{C}$. Because the methanation reaction is exothermic, equilibrium is favored by lower temperatures. Commercially, both reactions take place at about 40 atm.

During both the methanation and reforming reactions, it is possible for the Bouduard reaction to take place, depositing carbon on the catalyst:

$$
2 \mathrm{CO} \rightarrow \mathrm{CO}_{2}+\mathrm{C} \psi
$$

This reaction will deactivate the catalyst and must be avoided in any commercial operation. A solution of the equilibrium relationships shows that at. normal operating temperature this reaction will not take place if the feed steam-to-methane ratio in the reforming reactor is greater than $1: 1$ and if the $\mathrm{H}_{2}: \mathrm{CO}$ ratio in the methanation reactor is greater than $3: 1.49$

The impetus for developing this system has been an interest in an economical and efficient means to transport energy over long distances. The transportation system concept is based on piping the reactant gas to a user location where the heat is removed through the methanation reaction and used to generate steam for electrical power or district heating. However, this analysis includes both the transportation system and an onsite energy storage and peaking power system.

Basically, the chemical storage peaking power system consists of three sections: (1) the base-load nuclear steam reformer, (2) a gas storage system, and (3) the peaking power methanation section. Figure 22 is a schematic of this system.

Initially, methane and steam are catalytically reacted in a heliumheated reformer. The product gas is then cooled; the water is condensed and removed. The dry synthesis gas is then sent to a high-pressure 


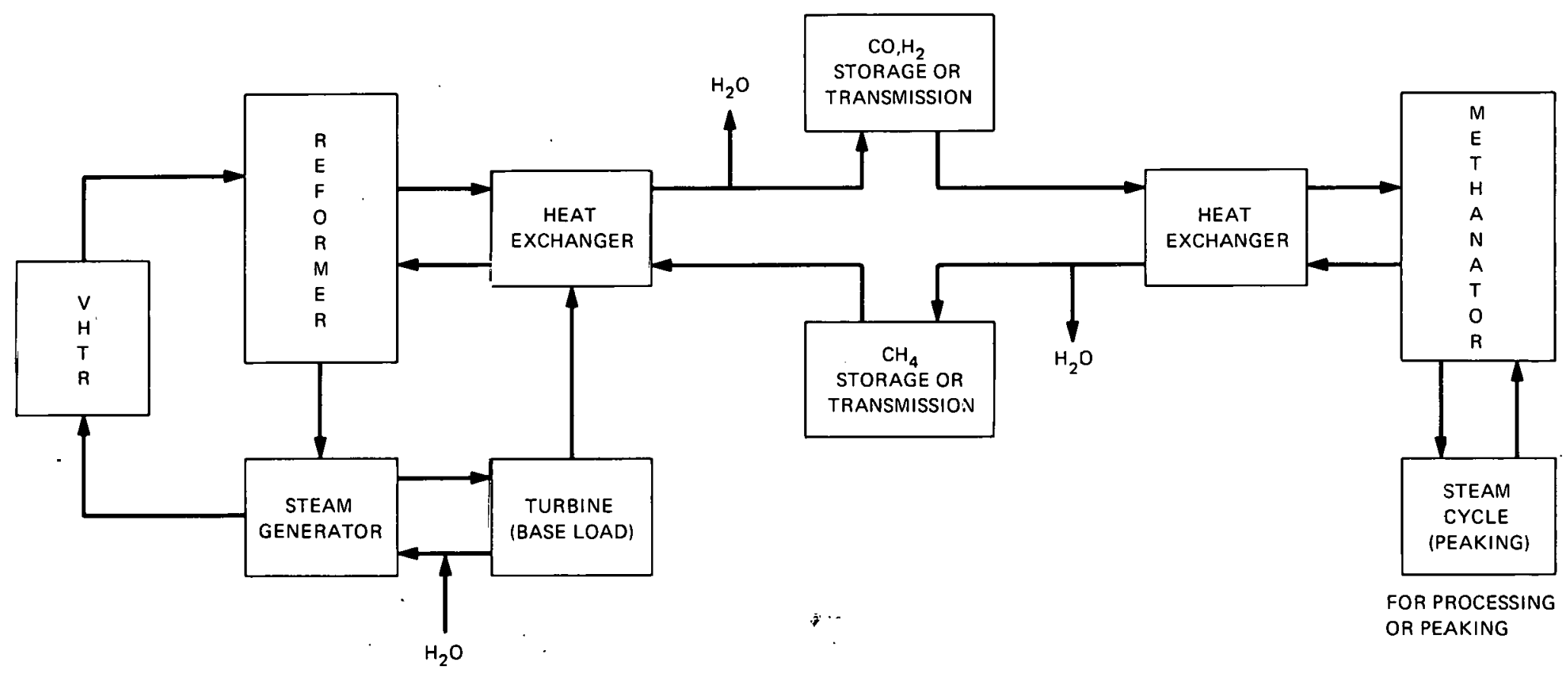

Fig. 22. EVA-ADAM system for transportation or peaking power generation. 
storage area where it awaits conversion in the peaking section. During peak power consumption periods, the gas is removed from storage, preheated, and catalytically methanated in a reactor-steam generator unit. Here the heat of reaction is extracted, producing high-pressure steam which, in turn, is used to produce peaking power. The product gas, consisting primarily of methane and steam, is then cooled; the water is condensed and removed. Some of the methane is returned to the reforming section, and the remainder is sent to a high-pressure storage area for later use.

The storage of gases can be accomplished by several methods, of which three appear to be feasible: (1) high-pressure tank storage, (2) storage in aquifers, and (3) storage in mined caverns or dissolvedsalt cavities. High-pressure tank storage can be accomplished in conventional high-pressure tanks located on the plant site. This method would have a high capital cost but is not restricted to any plant 1ocation. Aquifer storage, a technique that has had some development and application in the natural gas industry, is simply high-pressure storage in sedimentary rock formations called aquifers. These formations usually consist of a sandstone sublayer covered with a 20 - to 200-ft impermeable "caprock." To store gas, a hole is drilled to a depth of 500 to $2000 \mathrm{ft}$. The gas is then injected into the sedimentary sublayer where it displaces the entrained water. The capillary action of the water contains the gas, and a pseudo-bubble is formed in the rock. In this manner a large volume of high-pressure gas may be stored at a relatively small capital expenditure. The third alternative in the storage of gases encompasses two techniques that are similar in concept but slightly different in economics. They are storage in mined caverns and in dissolved-salt cavities. In both cases an underground void is used to store the gas. This type of storage may be applicable in regions where sedimentary rock formations do not exit.

'The alternative energy transport system is similar to the system previously described, except that the product synthesis gas is piped in a compressed gas plpeline rather than being stored. At the user end, the synthesis gas is methanated and the heat of reaction removed by producing process steam.

\section{2 .1 Results}

The EVA-ADAM peaking power system is very capital-intensive. As can be seen by Table 27, the capital investment constitutes the major portion of the total annual cost, far outweighing the operating, maintenance, and fuel expenses. These high capital costs are, of course, largely because of the high cost of the nuclear island (reactor, reformer, and steam generator) and the power generating equipment; but, as can be seen by Fig. 23, the cash outlays for gas-to-gas heat transfer equipment in the loop and the methanator-steam generator section are significant. Additionally, the storage costs could be quite high, depending on the technique used, and could determine whether or not the system is economical. 
Table 27. Economic analysis of EVA-ADAM peaking power plant

\begin{tabular}{|c|c|}
\hline Item & Cost $\left(10^{6} \$\right)$ \\
\hline VHTR & $(600$ to 800$)$ \\
\hline Base load turbine generator & 87 \\
\hline Peak load turbine generator & 369 \\
\hline $\mathrm{H}_{2}$ storage (aquifer) & 3.2 \\
\hline $\mathrm{CH}_{4}$ storage (aquifer) & 1.0 \\
\hline Base-plant heat exchanger & 55 \\
\hline Peak-plant heat exchanger & 103 \\
\hline Methanator-steam generator & 132 \\
\hline Gas inventory & 1.1 \\
\hline Total capital cost & (1351 to 1551$)$ \\
\hline Annual capital cost & $(203 \text { to } 233)^{\alpha}$ \\
\hline $\begin{array}{l}\text { Annual operating and maintenance } \\
\text { cost }\end{array}$ & 17.8 \\
\hline Annual fuel cycle $\cos t$ & $34 \cdot 3^{b}$ \\
\hline $\begin{array}{l}\text { Total annual cost (before-base } \\
\text { load credit) }\end{array}$ & (255 to 285$)$ \\
\hline Base-load power credit & $22^{c}$ \\
\hline $\begin{array}{l}\text { Total annual cost (after base- } \\
\text { load credit) }\end{array}$ & (233 to 263$)$ \\
\hline $\begin{array}{l}\text { Total peaking power produced } \\
\text { (per year) }\end{array}$ & $\left(4.11 \times 10^{9} \mathrm{kWhr}\right)$ \\
\hline Unit cost of peaking power & ( $56 . /$ to $64.0 \mathrm{mills} / \mathrm{kWhir}$ ) \\
\hline Peaking power generated & $2207 \mathrm{MW}(\mathrm{e})^{d}$ \\
\hline Base load power generated & $248 \operatorname{MW}(e)$ \\
\hline
\end{tabular}




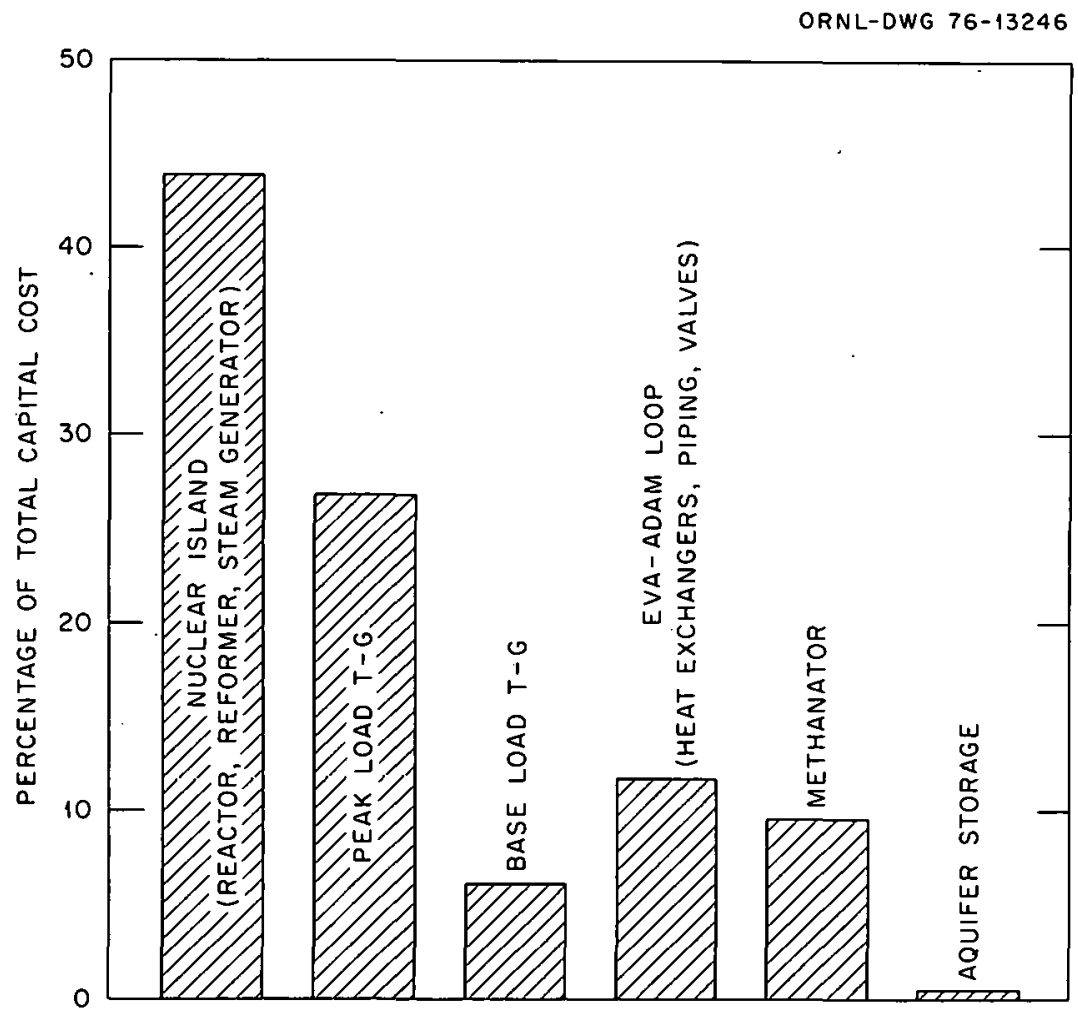

Fig. 23. Cost distribution for EVA-ADAM storage system.

A cost analysis using various high-pressure gas storage techniques shows that with high-pressure tank storage the capital costs become prohibitive. Figure 24 is a plot of peaking power costs (mills $/ \mathrm{kWhr}$ ) vs the assumed overall heat transfer coefficients in the gas-to-gas heat exchangers using three storage techniques: aquifer storage, mined cavern storage, and high-pressure tank storage. It can be inferred from these results that without a low-cost underground storage technique, this system will in all probability never be economically feasible. It can also be deduced from this plot that the system's costs are somewhat sensitive to the effectiveness of the heat transfer equipment. With an overall heat transfer coefficient below $30 \mathrm{Btu} \mathrm{hr} \mathrm{ft}^{-1} \mathrm{ft}^{-2}{ }^{\circ} \mathrm{F}^{-1}$, the capital costs for the heat exchange equipment become important. This will, of course, be a tradeoff of capital costs and pumping power; but, as also can be seen from Fig. 24, increasing the heat transfer coeffi-

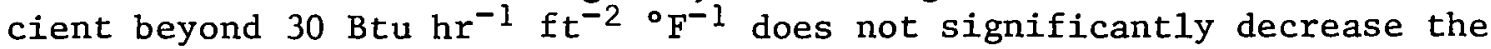
system cost.

The steam-to-methane ratio is another design parameter of significant interest. However, in the configuration used in this analysis the peaking cost was insensitive to the steam-to-methane ratio because the gain in reaction conversion was offset by higher capital costs and more energy waste. 


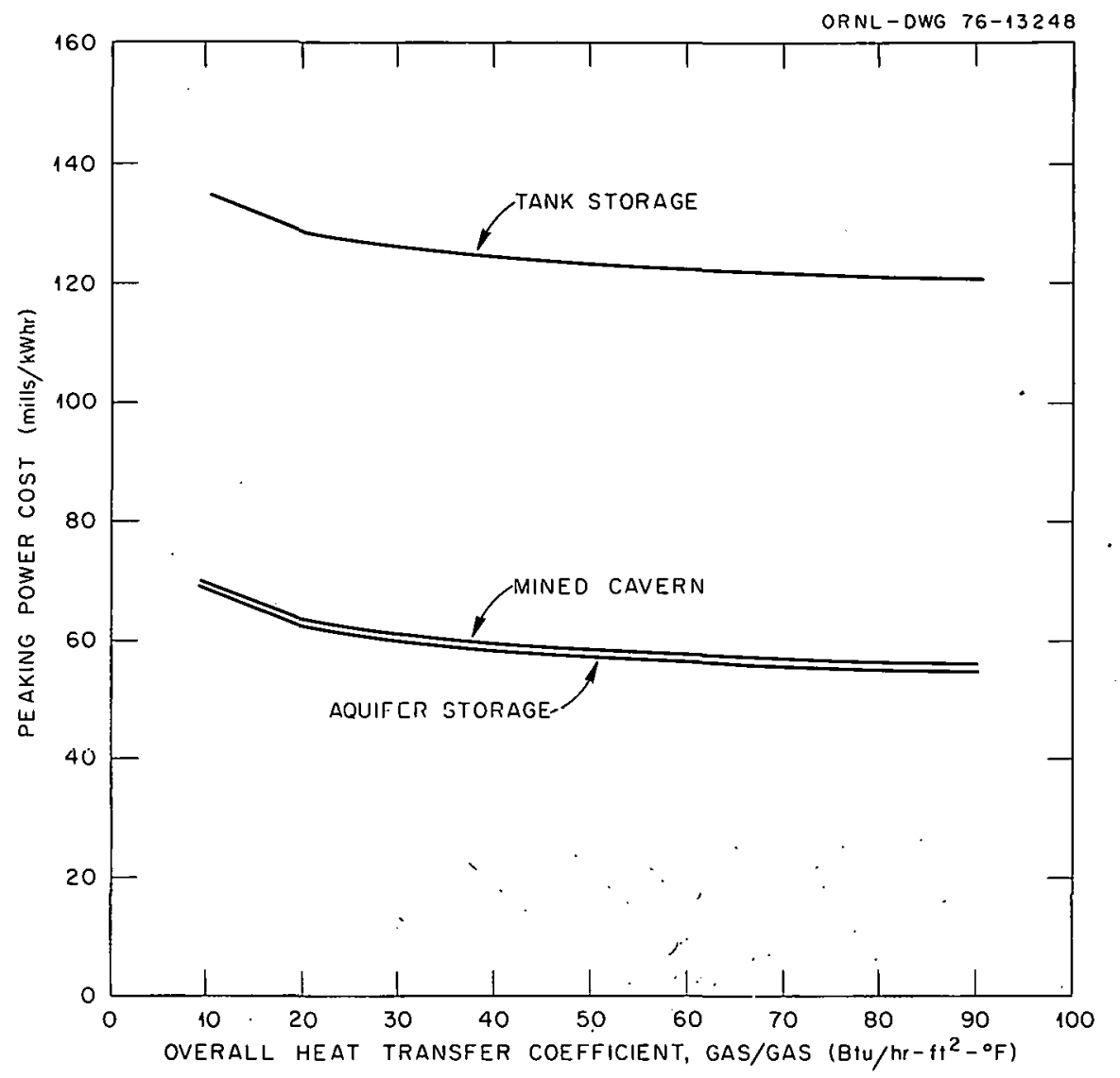

Fig. 24. EVA-ADAM peaking power costs for various storage techniques.

As with the peaking system, an EVA-ADAM pipeline is highly capitalintensive, as is depicted in Table 28. In addition to the inherent high capital costs of a nuclear energy source, the pipeline costs are high. Transportation costs are substantially higher than those for synthetic pipeline gas or hydrogen because (1) the heat of reaction is lower; (2) two pipelines are required; (3) the reaction conversion is much lower in the reforming methane reaction than in straight oxidation; and (4) because of the stoichiometry, four times as many reactants must be transported.

\subsubsection{Detailed system description}

The configuration used in this analysis is the same for both the storage and the transportation systems (Fig. 25). The power source is a $3000-M W(t)$ VHTR cooled by a helium-heated steam reformer and steam generator. The reformer is a series of tubes packed with nickel catalyst and which contains an inner regenerative return line similar in design 
Table 28. EVA-ADAM pipeline cost summary

\begin{tabular}{|c|c|}
\hline Item & Costs $\left(\$ \times 10^{6}\right)$ \\
\hline \multicolumn{2}{|l|}{ Capital costs } \\
\hline VHTR & 600 to 800 \\
\hline Base-load turbine generator & 87 \\
\hline Heat exchangers & 101 \\
\hline Methanator & 13 \\
\hline \multicolumn{2}{|l|}{ Pipeline } \\
\hline Pipe, cost per mile & 1.7 \\
\hline Compressor, cost per mile & 0.3 \\
\hline Total & 801 to $1001+2 / \mathrm{mile}$ \\
\hline \multicolumn{2}{|l|}{ Annual costs } \\
\hline Capital @ 15\% FCR & 120 to $150+0.3 / \mathrm{mile}$ \\
\hline Operating and maintenance & 17.8 \\
\hline Fuel & 34.3 \\
\hline Pumping, cost per mile & 0.05 \\
\hline Total & 172 to $202+0.35 / \mathrm{mile}$ \\
\hline $\begin{array}{l}\text { Electrical credit @ } 12 \mathrm{mills} / \mathrm{kWhr} \text {, } \\
\text { cost per mile }\end{array}$ & 22 \\
\hline Total cost & 150 to $180+0.35 / \mathrm{mile}$ \\
\hline Product cost & $\begin{array}{l}3.42 \text { to } 4.10 \$ / 10^{6} \mathrm{Btu} \\
+0.008 \$ / 10^{6} \mathrm{Btu} / \mathrm{mile}\end{array}$ \\
\hline Total heat transported & $1770 \mathrm{MW} .\left(6.04 \times 10^{9} \mathrm{Btu} / \mathrm{hr}\right)$ \\
\hline Total steam heat produced & $1730 \mathrm{MW}\left(5.9 \times 10^{9} \mathrm{Btu} / \mathrm{hr}\right)$ \\
\hline
\end{tabular}

to that being studied by GE and the German KFA. 50 The steam generator is heated with helium exhausted from the reformer and produces steam at $950^{\circ} \mathrm{F}$ and $2400 \mathrm{psi}$. This steam is used to produce base-load power and to supply feed steam for the methane-steam reformer. The base-load plant is patterned after an HTGR cycle ${ }^{51}$ as detailed by the cycle conditions listed in Table 29. Deviations from the standard HTGR cycle are: (1) the auxiliary equipment is assumed to be motor driven; (2) the feed heating is external; and (3) part of the high-pressure turbine exhaust is fed to the reformer and the remainder fed to the reheater, which is also external. 
ORNL-DWG 76-13249
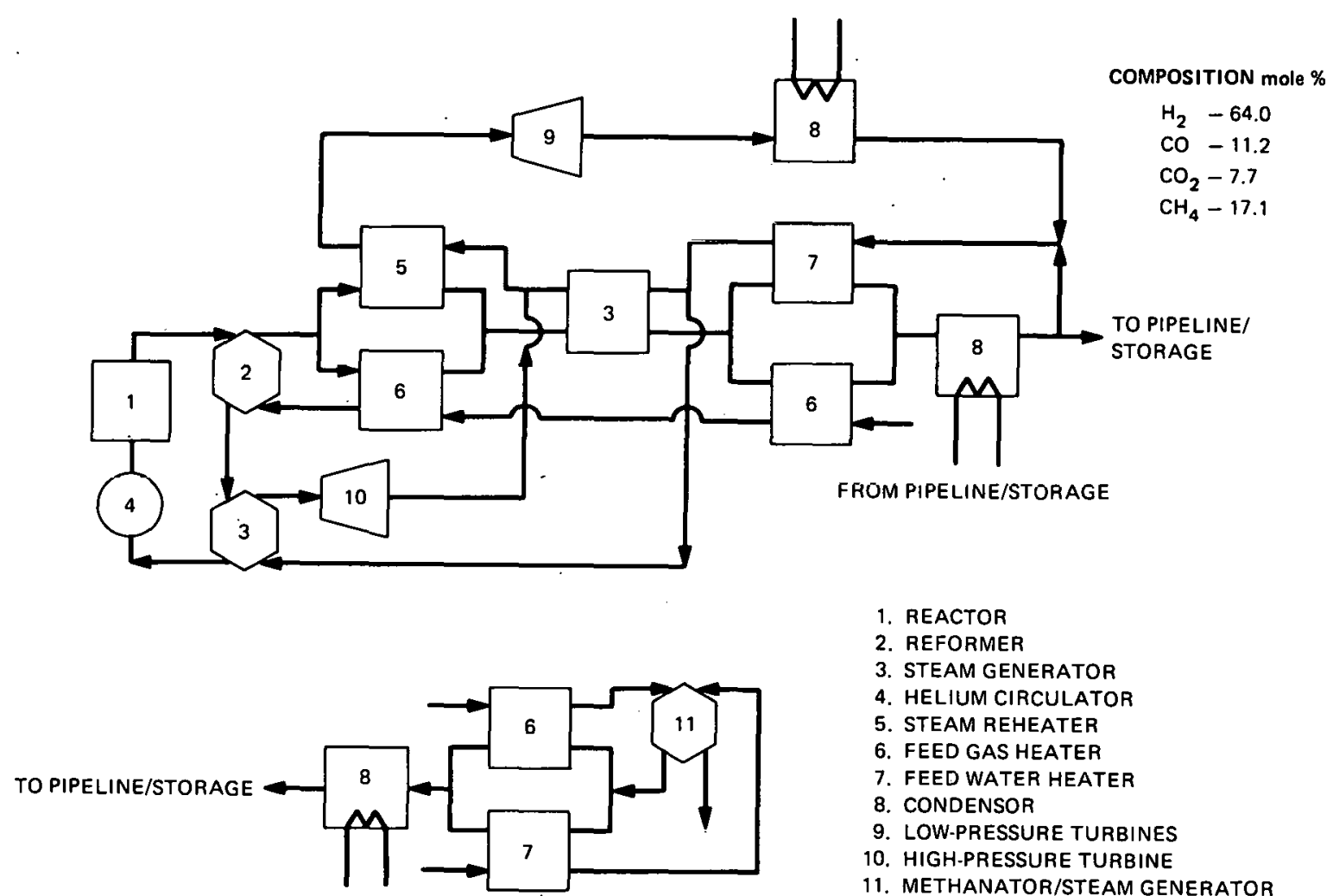

1. REACTOR

2. REFORMER

3. STEAM GENERATOR

4. HELIUM CIRCULATOR

5. STEAM REHEATER

6. FEED GAS HEATER

7. FEED WATER HEATER

8. CONDENSOR

9. LOW-PRESSURE TURBINES

10. HIGH-PRESSURE TURBINE

11. METHANATOR/STEAM GENERATOR

Fig. 25. Schematic of the EVA-ADAM energy transport and storage system.

The reformer feed steam is mixed with preheated methane and catalytically reacted in the reformer. The reaction is assumed to reach equilibrium and is exhausted through the inner tube which cools the product gases and supplies heat for the reaction. The product gas stream is split so that $20 \%$ goes to a steam reheater where it is cooled by superheating the steam to $1000^{\circ} \mathrm{F}$. The other $80 \%$ preheats the steam and methane feed. The product gases are again cooled in a steam generator which produces intermediate pressure steam for the process. The product gases are then used to provide heat to preheat the methane and to provide feed-water heating. Final gas cooling and water removal take place in a waste heat condenser. The dry synthesis gas is then either sent to an underground storage or it is transported in a compressed-gas pipeline.

In either system, the synthesis gas is removed from storage or the pipeline, preheated, and sent to a methanator. Within the methanator the heat of reaction is removed to produce steam at $825^{\circ} \mathrm{F}$ and $1000 \mathrm{psi}$. The product gas, primarily methane and steam, is cooled and the water condensed by preheating the feed gas and feed water. The product is finally cooled, and the remaining water is removed in a waste heat condenser. The methane product is returned by pipeline or sent to another storage area. 
Table 29. Base-load turbine-generator plant design data

\begin{tabular}{|c|c|c|c|c|}
\hline Item & $\begin{array}{l}\text { Temperature } \\
\quad\left({ }^{\circ} \mathrm{F}\right)\end{array}$ & $\begin{array}{l}\text { Pressure } \\
\quad \text { (psi) }\end{array}$ & $\begin{array}{l}\text { Enthalpy } \\
(\text { Btu/1b) }\end{array}$ & $\begin{array}{l}\text { Entropy } \\
\left(B t u / 1 b-{ }^{\circ} F\right)\end{array}$ \\
\hline Turbine throttle & 950 & 2400.00 & 1427.9 & 1.5099 \\
\hline Governing stage bow 1 & 944 & 2283.07 & 1427.9 & 1.5147 \\
\hline $\begin{array}{l}\text { Governing stage expansion line end point and } \\
\text { upper energy end point, high-pressure bowl }\end{array}$ & 871 & 1761.96 & 1399.4 & 1.5188 \\
\hline $\begin{array}{l}\text { High-pressure section expansion line end } \\
\text { point }\end{array}$ & 594 & 594.10 & 1286.8 & 1.5303 \\
\hline High-pressure section upper energy end point & 597 & 594.10 & 1288.3 & 1.5318 \\
\hline Reheater inlet & 596 & 589.90 & 1288.3 & 1.5325 \\
\hline Reheater outlet & 1018 & 579.30 & 1527.3 & 1.7257 \\
\hline Intermediate-pressure section bowl & 1017 & 554.00 & 1527.3 & 1.7305 \\
\hline $\begin{array}{l}\text { Intermediate-pressure section expansion line } \\
\text { end point }\end{array}$ & 661 & 143.30 & 1356.9 & 1.7445 \\
\hline $\begin{array}{l}\text { Intermediate-pressure section upper energy } \\
\text { end point }\end{array}$ & 664 & 143.30 & 1358.4 & 1.7459 \\
\hline Low-pressure section bow 1 & 663 & 139.00 & 1358.4 & 1.7492 \\
\hline Low-pressure section expansion line end point & 101 & 0.98 & 1011.4 & 1.8116 \\
\hline Low-pressure section upper energy end point & 101 & 0.98 & 1040.3 & 1.8631 \\
\hline Condenser hot well & 101 & 0.98 & 69.1 & 0.1315 \\
\hline Feedwater pump outlet & 106 & 3000.00 & 81.9 & \\
\hline Final feedwater after waste heat input & 565 & 3000.00 & 564.1 & \\
\hline
\end{tabular}


The peaking plant was sized to receive the entire thermal production in a 6-hr period. The turbine generator plant does not follow a particular cycle, but the cycle conditions (Table 30) represent a lower limit for fossil-type systems.

\subsubsection{Economic methodology}

The economic analysis for the EVA-ADAM peaking power and transportation system was conducted using the data listed in Table 31. The estimated capital cost of the VHTR was taken to be between $\$ 600$ and $\$ 800$ mlliion. ${ }^{4}$ The $\$ 600$-million VHTR may be considered either a lower estimate VHTR or one without an IHX. The VHTR capital costs are that of a nuclear island consisting of a reactor, a steam generator, and a reformer: These costs do not include reactor or material development and were assumed to be independent of the steam-to-methane ratio. The high-pressure storage areas for the peaking system were assumed to have the same costs as those for conventional storage of hydrogen and methane. These costs were developed from data in ref. 52 and are listed in Table 32 for various storage techniques. The turbine generator costs were derived with the aid of ref. 53.

Transportation costs were calculated assuming a conventional gas pipeline and electric driven compressors. The pipe and pump costs were derived from ref. 54 .

Heat exchangers for the EVA-ADAM loop were priced on the basis of cost per unit area of heat transfer surface. Each exchanger was assigned a basic unit cost based on the maximum operating temperature, pressure, and material considerations. The heat transfer surface areas were calculated after determining the heat transfer rates, mean temperature differences, and assumed overall heat transfer coefficients. Additionally, the costs of piping, valves, labor, controls, etc., were determined by multiplying the exchanger costs by an adjustment factor. The methanator capital costs were based on cost per unit area of heat transfer surface. This assumes that the reaction is heat-transfer-limited and is justified by the relatively high temperature at which the methanator would operate.

The annual operating and maintenance (O\&M) costs were obtained as a multiple of the equivalent O\&M costs for an HTGR obtained from the ORCOST computer code.55 The component costs of staff, maintenance, material, supplies, and expenses were each increased by $50 \%$ to adjust for the additional plant size; insurance, fees, administrative, and general expenses were not. Using the data from this code, a linear relationship between $0 \& M$ costs and power plant size was derived. Additionally, catalyst costs were added to the O\&M costs. The catalyst was assumed to have a life expectancy of four years at a unit cost of $\$ 300 / \mathrm{ft}^{3}$. The volume of catalyst needed was calculated using the assumption of a first-order reaction and the method developed in ref. 56. 
Table 30. Peak-load turbine-generator plant design data

\begin{tabular}{|c|c|c|c|c|}
\hline Item & $\begin{array}{l}\text { Temperature } \\
\quad\left({ }^{\circ} \mathrm{F}\right)\end{array}$ & $\begin{array}{l}\text { Pressure } \\
\quad(p s i)\end{array}$ & $\begin{array}{l}\text { Enthalpy } \\
(B t u / 1 b)\end{array}$ & $\begin{array}{c}\text { Entropy } \\
\left(B t u / 1 b-{ }^{\circ} F\right)\end{array}$ \\
\hline Turbine throttle & 825 & 1250.00 & 1392.8 & 1.5474 \\
\hline Governing stage bowl & 820 & 1189.10 & 1392.8 & 1.5524 \\
\hline $\begin{array}{l}\text { Governing stage expansion line end point and } \\
\text { upper energy end point, high-pressure bowl }\end{array}$ & 751 & 906.40 & 1364.2 & 1.5566 \\
\hline $\begin{array}{l}\text { High-pressure section expansion line end } \\
\text { point }\end{array}$ & 431 & 214.50 & 1227.2 & 1.5715 \\
\hline High-pressure section upper energy end point & 433 & 214.50 & 1228.7 & 1.5732 \\
\hline Reheater inlet & 433 & 213.00 & 1228.7 & 1.5739 \\
\hline Reheater outlet & 825 & 209.10 & 1437.3 & 1.7705 \\
\hline Low-pressure section bowl & 824 & 200.00 & 1437.3 & 1.7753 \\
\hline Low-pressure section expansion line end point & 101 & 0.98 & 1025.1 & 1.8360 \\
\hline Low-pressure section upper energy end point & 101 & 0.98 & 1058.1 & 1.8948 \\
\hline Condenser hot well & 101 & 0.98 & 69.1 & 0.1315 \\
\hline Feedwater pump outlet & 104 & 1562.50 & 75.8 & \\
\hline Final feedwater after waste heat input & 311 & 1562.50 & 283.4 & \\
\hline
\end{tabular}


Table 31. EVA-ADAM cost estimate basis

\begin{tabular}{ll}
\hline Nuclear fuel & $\$ 0.45 / 10^{6} \mathrm{Btu}$ \\
Electricity & $\$ 0.012 / \mathrm{kWhr}$ \\
Fixed charge rate & 0.15 \\
Interest during construction & $8 \%$ \\
Date of first commercial operation & 1982 \\
Standard operating year & 310 days \\
Steam: methane ratio & 2 \\
\hline
\end{tabular}

Table 32. Cost comparison for methane and hydrogen storage at $15.6^{\circ} \mathrm{C}\left(60^{\circ} \mathrm{F}\right)$ [estimated capital cost for storing $1 \mathrm{~kg}$-mole at 6.894 $\mathrm{MPa}(1000 \mathrm{psi})]$

\begin{tabular}{lcc}
\hline \multicolumn{1}{c}{ Storage system } & \multicolumn{2}{c}{ Cost (\$) } \\
\cline { 2 - 3 } & $\mathrm{CH}_{4}$ & $\mathrm{H}_{2}$ \\
\hline Underground storage (aquifer) & 0.66 & 0.8162 \\
Dissolved-salt cavity & 1.89 & 2.32 \\
Mined cavern & 3.78 & 4.64 \\
Steel pipe (line packing) & 40.40 & 49.60 \\
Tank storage & 191.10 & 233.60 \\
\hline
\end{tabular}

\subsection{Heat Transfer Salt}

The EVA-ADAM system considers storage in the form of chemical energy. The heat transfer salt (HTS) system is based on thermal energy storage as sensible heat high-temperature salt.

In our analysis of the technology applicabie to supplyluy liightemperature thermal energy to a refinery, including the study by. General $\Lambda$ tomic (GA), it became apparent that the HTS, selected from a number of possible alternative heat transport fluids, would also be applicable for thermal storage for generation of intermediate-load and peaking electricity. 


\section{3 .1 Heat source}

The requirement for nuclear reactor technology is no more severe than for existing HTGR technology - a core outlet temperature of approximately $1300^{\circ} \mathrm{F}$ (the standard HTGR design has a core outlet temperture of about $1400^{\circ} \mathrm{F}$ ). The reactor may be thought of as either a VHTR or a process-heat HTGR. In the study of heat transport to a refinery via HTS, GA indicated that two major modifications would be made to the HTGR PCRV internals: (1) the steam generators would be replaced by primary helium to secondary helium heat exchangers; and (2) the number of primary reactor cooling loops would be reduced (from 4 to 3 for the $2000-\mathrm{MW}(\mathrm{t}) \mathrm{plan} t) .42$

\section{$2.3 .2 \underline{\text { Salt }}$}

Heat transfer salt is a eutectic mixture of potassium nitrate $\left(\mathrm{KNO}_{3}\right)$, sodium nitrite $\left(\mathrm{NaNO}_{2}\right)$, and sodium nitrate $\left(\mathrm{NaNO}_{3}\right)$. Developed by du Pont in the 1930s for use in the chemical and petroleum process industries, HTS is economical and has good heat transfer properties. The usual composition by weight is $53 \% \mathrm{KNO}_{3}, 40 \% \mathrm{NaNO}_{2}$, and $7 \% \mathrm{NaNO}_{3} .57$ Some of the more important physical properties of HTS for this application include its low melting point $142^{\circ} \mathrm{C}\left(288^{\circ} \mathrm{F}\right)$, thermal conductivity $\left(0.33 \mathrm{Btu} \mathrm{hr} \mathrm{ft}^{-1}{ }^{\circ} \mathrm{F}^{-1}\right)$, specific heat $\left(0.373 \mathrm{Btu} 1 \mathrm{~b}^{-1}{ }^{\circ} \mathrm{F}^{-1}-\right.$ see Fig. 26), density (see Fig. 27), viscosity (see Fig. 28), and heat transfer coefficient ( 800 to $2900 \mathrm{Btu} \mathrm{hr} \mathrm{ft}^{-2}{ }^{\circ} \mathrm{F}^{-1}$, over a wide range of temperatures and velocities). Heat transfer salt has been widely used in many industrial applications and in very large volumes. For example, one Houdry catalytic cracking and refining unit uses on the order of $1 \times 10^{6}$ lb of HTS. 57

Vendor and open literature publications recommend use of HTS up to $1100^{\circ} \mathrm{F}, 58-63$ although data on thermal stability at high temperatures are not adequate. A literature study on HTS, along with some experimental data, are presented by Bohlmann in a 1972 report. 57 The generally accepted overall thermal decomposition reaction for HTS is:

$$
5 \mathrm{NaNO}_{2} \rightarrow 3 \mathrm{NaNO}_{3}+\mathrm{Na}_{2} \mathrm{O}+\mathrm{N}_{2} \text {. }
$$

This stoichiometry was used to analyze decomposition as a function of temperature. Despite the disparate conditions of the various investigations, the results are relatively consistent. Based on the data presented in Fig. 29, estimated amounts of salt replacement have been calculated for $1100^{\circ}$ and $1000^{\circ} \mathrm{F}$ operation.

Corrosion data presented in the aforementioned report indicate that HTS has been satisfactorily handled on a long-term basis in stainless steel equipment up to $1100^{\circ} \mathrm{F}$ and in carbon steel up to about $850^{\circ} \mathrm{F}$. 


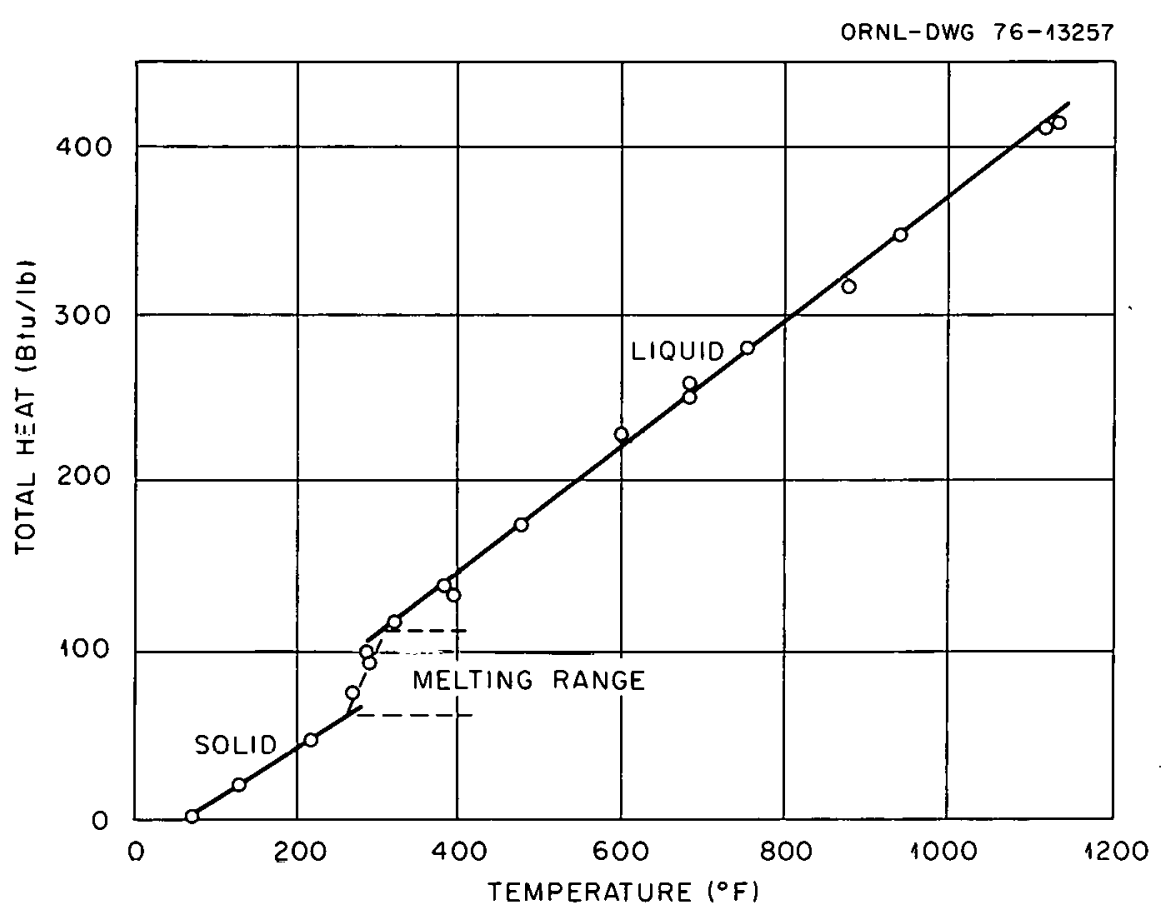

Fig. 26. Enthalpy of HTS vs temperature.

\subsubsection{System description}

Figure 30 is a schematic diagram of an electric peaking power generating system based un HTS energy storage. The economic analysis considers $1000^{\circ}$ and $1100^{\circ} \mathrm{F}$ maximum salt temperature with and without an IHX. The more conservat1ve case is illustrated $\left(1000^{\circ} \mathrm{F}\right.$ with IHX). The 3000-MW(t) system will provide $200 \mathrm{MW}(\mathrm{e})$ continuously and 3667 MW(e) for $6 \mathrm{hr} /$ day (peaking power). The system is designed to store 43,200 MWhr of thermal energy. The peaking plant turbine cycle is essentially the same as an HTGR power cycle, and the base-load turbine cycle is the same as a boiling-water-reactor power cycle.

\subsubsection{Economic analysis}

Table 33 presents a summary of the preliminary economic analysis nf the HTS peaking power storage plant. Case 4 at $1000^{\circ} \mathrm{F}$ with an IHX is the reference case.

Costs included for the VHTR and IHX are those derived in ORNL's VHTR assessment which were intended for higher temperature application. General Atomic's estimate of these costs, as presented in their refinery study, ${ }^{42}$ is markedly less. Obviously, a better definition of cost for this particular application is desirable. We believe ours is a very 


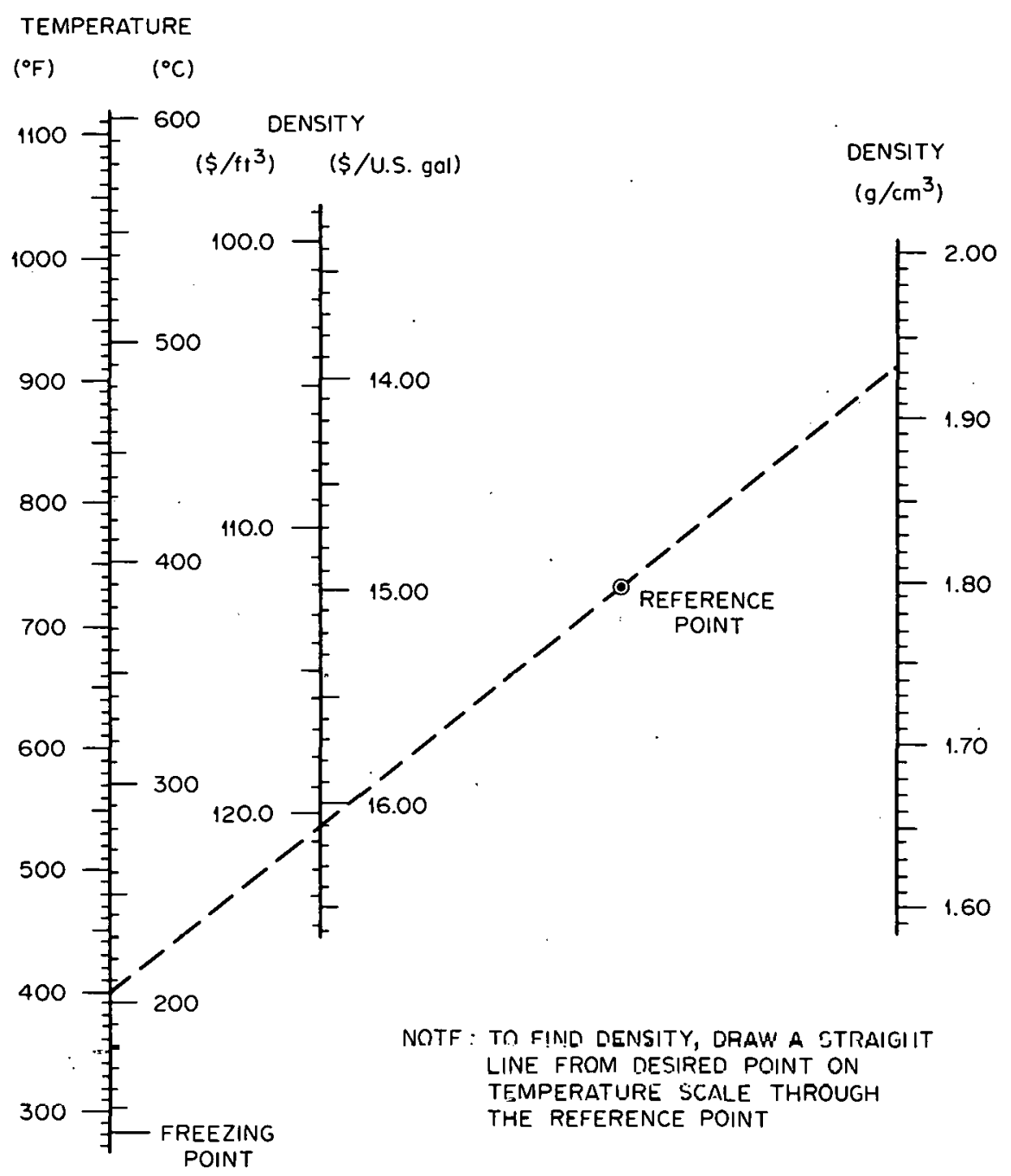

Fig. 27. Density of liquid HTS.

conservative assessment of the economic potential of the concept. There appears to be some reasonable possibility of improving the competitive position of the HTS storage system relative to current estimates with a more thorough and detailed analysis. 
ORNL DWG $76-20628$

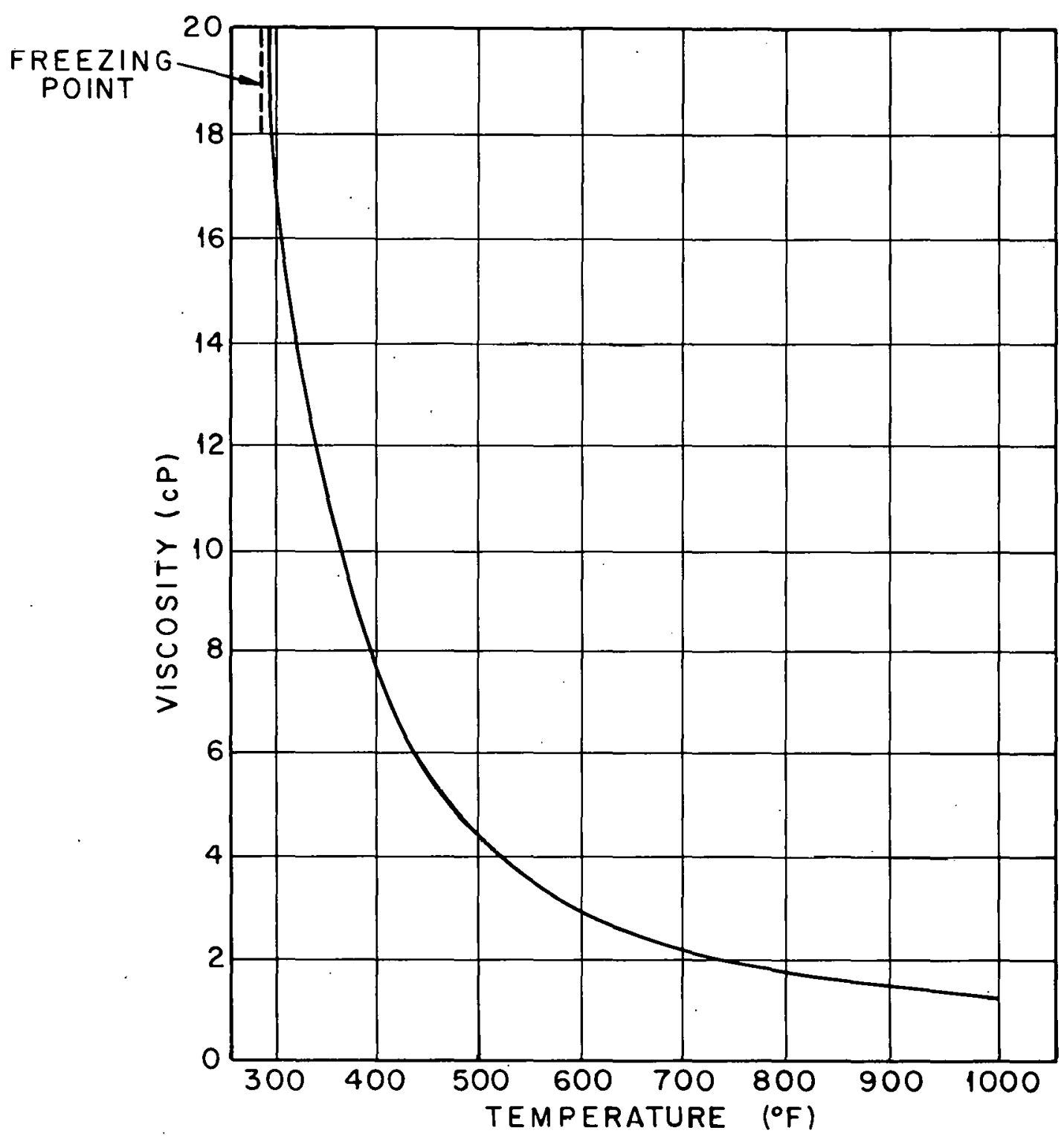

Fig. 28. Viscosity of liquid HITEC. 


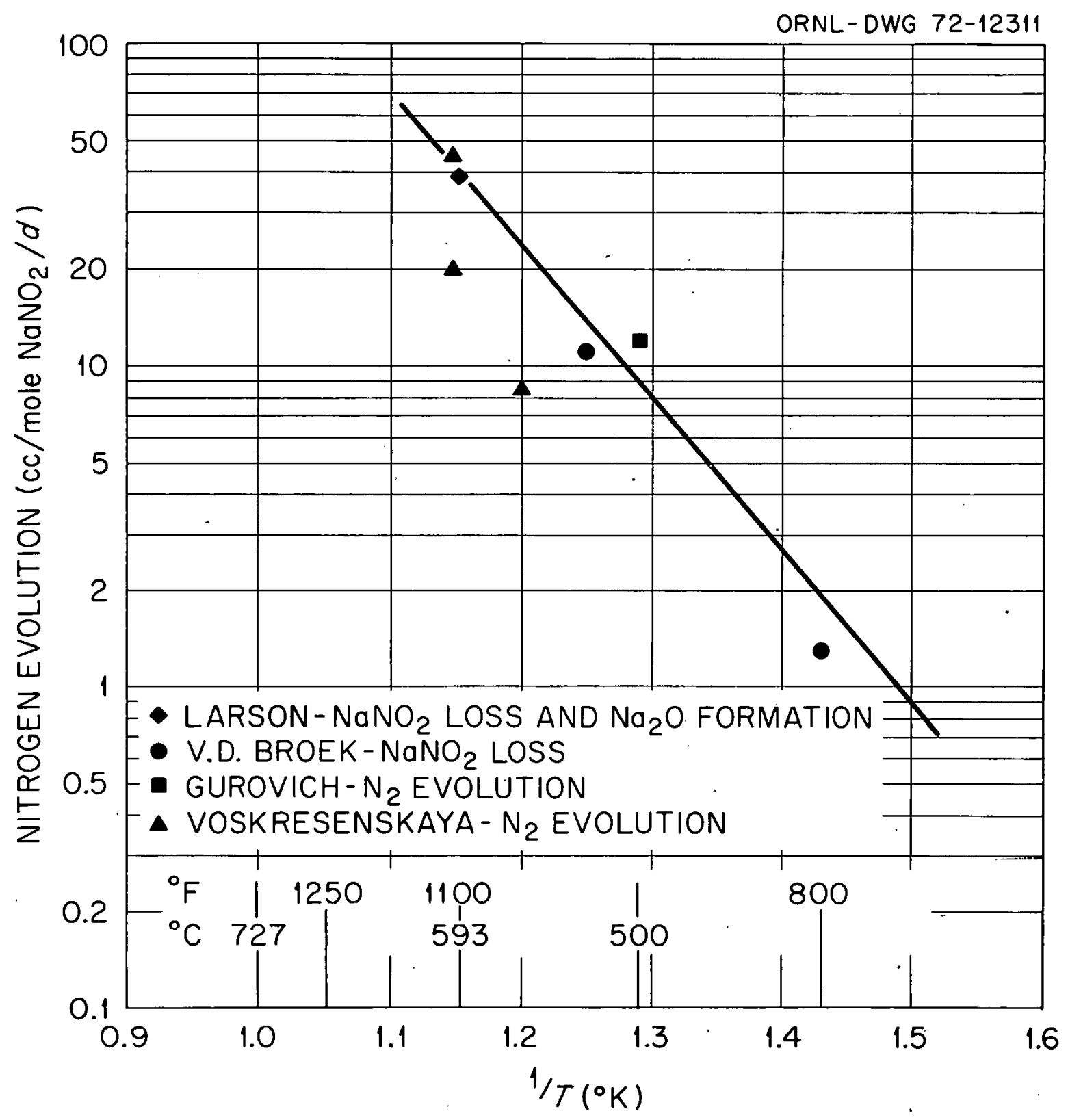

Fig. 29. Rate of nitrogen evolution from HTS vs temperature. 


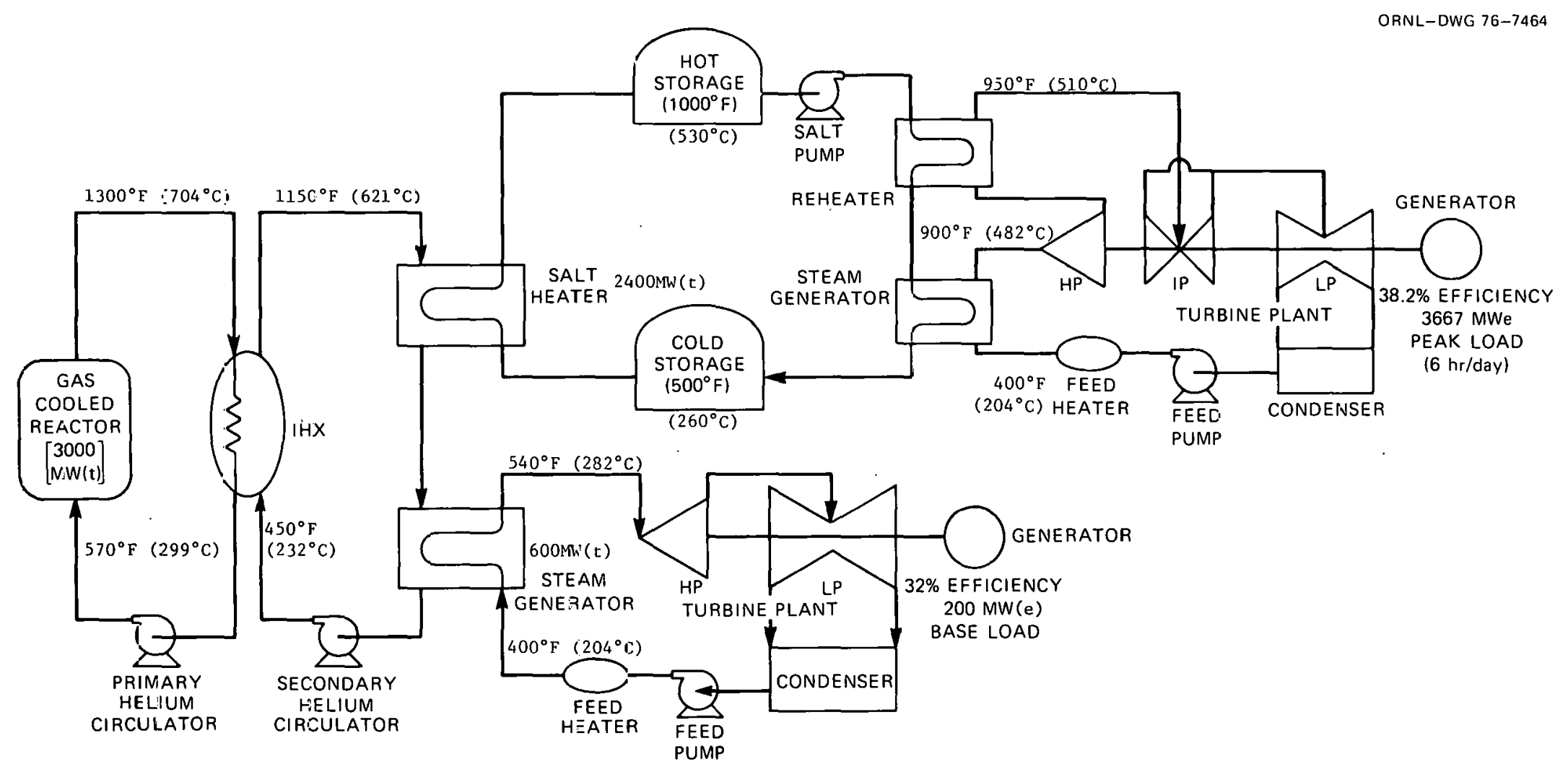

Fig. 30. VHTR peaking power system using HTS storage. 
Table 33. Pre.lminary economic analysis of HTS peaking power plant

\begin{tabular}{|c|c|c|c|c|c|}
\hline \multirow{3}{*}{ Item } & \multicolumn{4}{|c|}{ Direat and indirect costs $\left(\$ \times 10^{\epsilon}\right)$} & \multirow{3}{*}{ Comments } \\
\hline & \multicolumn{4}{|c|}{$\begin{array}{l}\text { Salt temperature of: } \\
1100^{\circ} \mathrm{F} \\
1000^{\circ} \mathrm{F}\end{array}$} & \\
\hline & $\begin{array}{l}\text { Withou: } \\
\text { IHX }\end{array}$ & $\begin{array}{l}\text { W1th } \\
\text { IHX }\end{array}$ & $\begin{array}{l}\text { Without } \\
\text { IHX }\end{array}$ & $\begin{array}{l}\text { With } \\
\text { IHX }\end{array}$ & \\
\hline \multicolumn{6}{|l|}{ Capital cost } \\
\hline VHTR & 600 & 600 & 600 & 600 & $\begin{array}{l}\text { Includes steam generator and process heat } \\
\text { exchanger. }\end{array}$ \\
\hline IHX & & 100 & & 100 & Based on data in VHTR evaluation report. \\
\hline $\begin{array}{l}\text { Turbine 1sland (HTGR cycle) } \\
\text { 3744-MW(e) peaking plant }\end{array}$ & 599 & 599 & 599 & 599 & $\begin{array}{l}\text { Scaled directtly from HTGR turbine island } \\
\text { cost data. }\end{array}$ \\
\hline $\begin{array}{l}\text { Turbine 1sland (BWR cycle) } \\
200-M W(e) \text { base load }\end{array}$ & 36 & .36 & 36 & 36 & $\begin{array}{l}\text { Scaled directly from BWR turbine island } \\
\text { cost data. }\end{array}$ \\
\hline Salt inventory & $\frac{140}{\left(6.7 \times 10^{8} 1 \mathrm{~b}\right)}$ & 140 & $\begin{array}{l}168 \\
\left(8.1 \times 10^{8} 1 \mathrm{~b}\right)\end{array}$ & 168 & $\begin{array}{l}\text { Based on } 20 c / 1 b \text { (scaled up from } 15 c / 1 b \text { ) } b, c \\
2400-M W(t) \text { storage for } 18 \mathrm{hr} \text {. }\end{array}$ \\
\hline Salt storage & $\left(6.4 \times 10^{6} \mathrm{ft}^{3}\right)$ & 95 & $\frac{114}{\left(7.4 \times 10^{6} \mathrm{ft}^{3}\right)}$ & 114 & $\begin{array}{l}\text { Estimated at } \$ 15 / \mathrm{ft}^{3} \text {; average density } \\
\quad 110 \mathrm{lb} / \mathrm{ft}^{3}\end{array}$ \\
\hline \multirow[b]{2}{*}{ Total capital cost } & 25 & 25 & 30 & 30 & \multirow[t]{2}{*}{ Estimated from data refinery study. ${ }^{b}$} \\
\hline & 1495 & 1595 & 1547 & 1647 & \\
\hline $\begin{array}{l}\text { Annual capital cost } \\
\text { Annual operating and maintenance } \\
\text { cost }\end{array}$ & $\begin{array}{r}224 \\
9\end{array}$ & $\begin{array}{r}239 \\
9\end{array}$ & $\begin{array}{r}232 \\
9\end{array}$ & $\begin{array}{r}247 \\
9\end{array}$ & $\begin{array}{l}15 \% \text { FCR. } \\
\text { Conservatively estimated at about twice conven- } \\
\text { tional HTGR plant of equivalent size. }\end{array}$ \\
\hline \multirow[t]{4}{*}{$\begin{array}{l}\text { Annual fuel cycle cost } \\
\text { Annual salt replacement cost }\end{array}$} & $\begin{array}{l}35 \\
56\end{array}$ & $\begin{array}{l}35 \\
56\end{array}$ & $\begin{array}{l}35 \\
20\end{array}$ & $\begin{array}{l}35 \\
20\end{array}$ & $\begin{array}{l}\text { Based on } 45 \mathrm{c} / 10^{6} \text { Btu at } 0.85 \text { plant factor. } \\
\text { Estimated from HTS decomposition rates.d }\end{array}$ \\
\hline & $\begin{array}{r}324 \\
18\end{array}$ & $\begin{array}{r}339 \\
18\end{array}$ & $\begin{array}{r}296 \\
18\end{array}$ & $\begin{array}{r}311 \\
18\end{array}$ & \multirow[t]{2}{*}{$12 \mathrm{mills} / \mathrm{kWhr} ; 1490 \times 10^{6} \mathrm{kWhr} /$ year at } \\
\hline & 296 & 321 & 278 & 293 & \\
\hline & \multicolumn{2}{|c|}{$6.97 \times 10^{9} \mathrm{kWhr} / \mathrm{yr}$} & \multicolumn{2}{|c|}{$6.83 \times 10^{9} \mathrm{kWhr} / \mathrm{yr}$} & $\begin{array}{l}39 \% \text { and } 38.2 \% \text { efficlencies for peaking power } \\
\text { cycles based on HTS at } 1100^{\circ} \text { and } 1000^{\circ} \mathrm{F} \\
\text { respectively. }\end{array}$ \\
\hline Unit cost of peaking power, $m i 1 \mathrm{is}_{\mathrm{s}} / \mathrm{kWhr}$ & 42.5 & 46.0 & 40.7 & 42.9 & $25 \%$ plant factor on a dally basis. \\
\hline
\end{tabular}

T. D. Anderson et al., An Assessment of Industrial Energy Options Based on Coal and Nuclear Systems, Report oRNL-4955, Oak R1dge National Laboratory, July 1975 .

$b_{J}$. Huntsinger et al., Process Heat in Petrolevon Refinery Applications - Final Report, Report GA-A13406, General Atomic Company, February 1976.

${ }^{c}$ E. G. Bohlman, Heat Trocnsfer Salt for High Terperature Stecon Generation, Report ORN/TM-3777, Oak R1dge National Laboratory, December 1972.

$d_{\text {Rates presented In F1g. } 27 .}$ 


\section{MATERIALS REQUIREMENTS FOR PROCESS HEAT EXCHANGERS}

Important factors that influence the selection of materials for heat exchanger applications are temperature, stress, environment, and operating lifetime. Although the stress on the PHX material will depend on the process design selected, the operation of the process at a pressure close to the coolant helium pressure will minimize tube stresses and creep rates in the PHX material. In view of the interaction between mechanical properties and environment, consideration must be given to the chemical compatibility of candidate materials with the process. The environments are expected to be made up of impure helium, hydrogen, steam, coal, ash, and various hydrocarbons.

In this analysis, families of alloys have been considered with the objective of recommending a smaller group of materials for each proposed operating condition. The families of materials selected are listed in Table 34 and cover the range of conventional construction materials currently used in high-temperature applications. Following a brief description of the critical operating conditions required for the steam reforming and steam-coall gasification processes, these families of materials will be reviewed with respect to the mechanical properties and compatibility requirements of the two processes. This is followed by a description of the Westinghouse thermochemical hydrogen process and a review of the materlals requirements for this process.

\subsection{Steam Reforming}

In conventional steam reforming plants, the energy for the endothermic reaction is supplied by burning ash- and sulfur-free hydrocarbons in preheated air. These combustion gases travel countercurrently to the process gae which flows through ratalyst-filled tubes. To reduce hydrocarbon consumption, nuclear process heat is being considered as the energy source for this process.

Where possible, the material evaluation of the VHTR reformer system will be based on the design of conventional fossil-fired reformers. A VHTR reformer design might incorporate straight tubes packed in a full tube field hung vertically from a single tubesheet. High-temperature helium enters at the bottom of the reformer and exits at the top. Process gases pass through the tubesheet and down the catalyst-filled tubes and are exhausted through semiflexible pigtails welded to the bottom of the tubes.

In conventional reformers, the pigtails are made from type 304 or 316 stainless steel. The catalyst tubes are typically $28 \mathrm{ft}$ long with a 1/2-in. wall thickness and are made from centrifugally cast alloys such as HK-40. The tubesheet is constructed of 304 stainless steel, wh1ch is clad on the top surface with a weld overlay of Incoloy 800 . 
Table 34. Representative candidate materials for initial screening

\begin{tabular}{ll}
\hline \multicolumn{1}{c}{ Categories of materials } & \multicolumn{1}{c}{ Exemplary grades } \\
\hline Stainless steels & Types $310,316,304$ \\
$\begin{array}{l}\text { Nickel-base alloys - solid solution } \\
\text { strengthened }\end{array}$ & Alloys 102,536,600,601, 617, \\
& $800 \mathrm{H}, 802,903, \mathrm{RA} 333$, \\
Nickel-base alloys - precipitation & Hastelloy X \\
strengthened & Alloys 702, X750, 901, n979, \\
& 718 Alloys U700, Waspaloy, Rene 95 \\
Cobalt-base alloys & Alloys L-605, HS-188 \\
Centrifugally cast alloys & Alloys HK-40, Supertherm, 519, \\
Oxide-dispersion-strengthened alloys & 657, Mo-Re 2, Manurite 36X \\
Refractory alloys & Alloys TDMi, TDMMiCR, IMMA-753 \\
Ceramic refractory & Molybdenum, Alloy TZM \\
\hline
\end{tabular}

\subsection{Steam-Coal Gasification}

In establishing criteria for the selection of material for the VHTR steam-coal gasifier, an earlier design study by the West Germans for the gasification of lignite can be used as a point of departure. 64 The proposed gasifier is a horizontal cylinder about $80 \mathrm{ft}$ long and $18 \mathrm{ft}$ in diameter. Coal is reacted in a fluidized bed in which a heat exchanger is located. Coal enters the gasifier at the upper right; ash and slag are withdrawn through an opening at the lower left. The bed is fluidized by high-temperature steam injected from below. Heated helium enters the heat exchanger from above, flows through tubes inside the bed, and then joins the collector tubes to leave the gasifier through an upper outlet. Although the specific operating temperature and pressure for the proposed gasifier were not specified, the design approach was to balance the pressure across the PHX tubes while operating the gasifier at the highest practical temperature. Operating temperatures of $1500^{\circ}$ to $1925^{\circ} \mathrm{F}$ were considered in the German study.

In addition to those corrosion conditions observed in steam reforming systems, materials in the fluidized-bed coal gasifiers will be subject to erosion-corrosion reactions with char and ash entrained in the steam and sulfidation from $\mathrm{H}_{2} \mathrm{~S}$ formed by the reduction of organic sulfur impurities in the coal. In their initial studies, the Germans explored the potential use of 310 stainless steel and Incoloy 800 for the tube material; however, these materials have shown only short-term usefulness in the $1700^{\circ}$ to $1900^{\circ} \mathrm{F}$ range. 


\subsection{High-Temperature Load-Carrying Capabilities}

With regard to the steam reformer and coal gasification systems, the principal factors influencing the useful life of the heat exchanger tubing will be load-carrying capability and corrosion resistance. The objective of this section will be to review the factors pertinent to the load-carrying abilities of candidate materials for heat exchanger tubing.

Commercial operation of these proposed systems will require the owners to obtain state and federal licenses. To obtain the appropriate license and insurance will require that the facilities be.designed and built in conformance with minimum standards provided by the technical community. In the petrochemical industry, the standards applied to gas-fired steam-methane reformers are those established by the American Petroleum Institute. Since no commercially operating coal-conversion system has been built in the United States, no precedent has been established regarding design and fabrication standards.

To protect the public, the design and fabrication of nuclear power stations are required to comply with Sect. III of the ASME Boiler and Pressure Vessel Code. With regard to the proposed nuclear-powered steam reformer and/or coal gasification systems, one could postulate that a failure of the process pressure vessel could lead to a rupture of the IHX. In turn, failure of the IHX could allow the release of reactor core gases. It is anticipated that this scenario could be used to require that the design and fabrication of the pressure vessels associated with steam reforming and coal gasification systems conform with Sect. III of the ASME Code. A review of the impact of such a decision on the selection of heat exchanger tube material follows.

Section III of the ASME Code was established to aid design and material selection for nuclear components. The ASME Code recognizes that different levels of importance can be associated with each component; therefore, there are three classes of nuclear components. Classes 1, 2, and 3 represent components with decreasing levels of design and inspection stringencies. Based on this scenario, the PHX would most likely be a class 1 component.

As written, Sect. III of the code gives design rules and stress intensity limits as a function of temperature up to $700^{\circ}$ and $800^{\circ} \mathrm{F}$ for ferritic and austenitic materials respectively. Code Case 1592 of Sect. III provides stress limits and revised design rules for the use of four alloys for class 1 components at temperatures in the creep range. This code case allows the use of 304 and 316 stainless steels to $1500^{\circ} \mathrm{F}$, Incoloy $800 \mathrm{H}$ to $1400^{\circ} \mathrm{F}$, and $2-1 / 4 \mathrm{Cr}-1$ Mo steel to $1200^{\circ} \mathrm{F}$. The maximum allowable stress intensities for these alloys for temperatures from $800^{\circ}$ to $1500^{\circ} \mathrm{F}$ are illustrated in Fig. 31 .

At these temperatures, creep strength is the limiting factor in the load-carrying capabilities of the candidate materials. At $1400^{\circ}$ to $1500^{\circ} \mathrm{F}$, the maximum allowable stress intensity limits for these Code Case 1592 approved materials range from 1100 to 3600 psi. Note that no materials have been approved for use at temperatures above $1500^{\circ} \mathrm{F}$.

When provided sufficient data, the Code Comnittees can establish stress intensity limits for Code-approved materials at temperatures in 


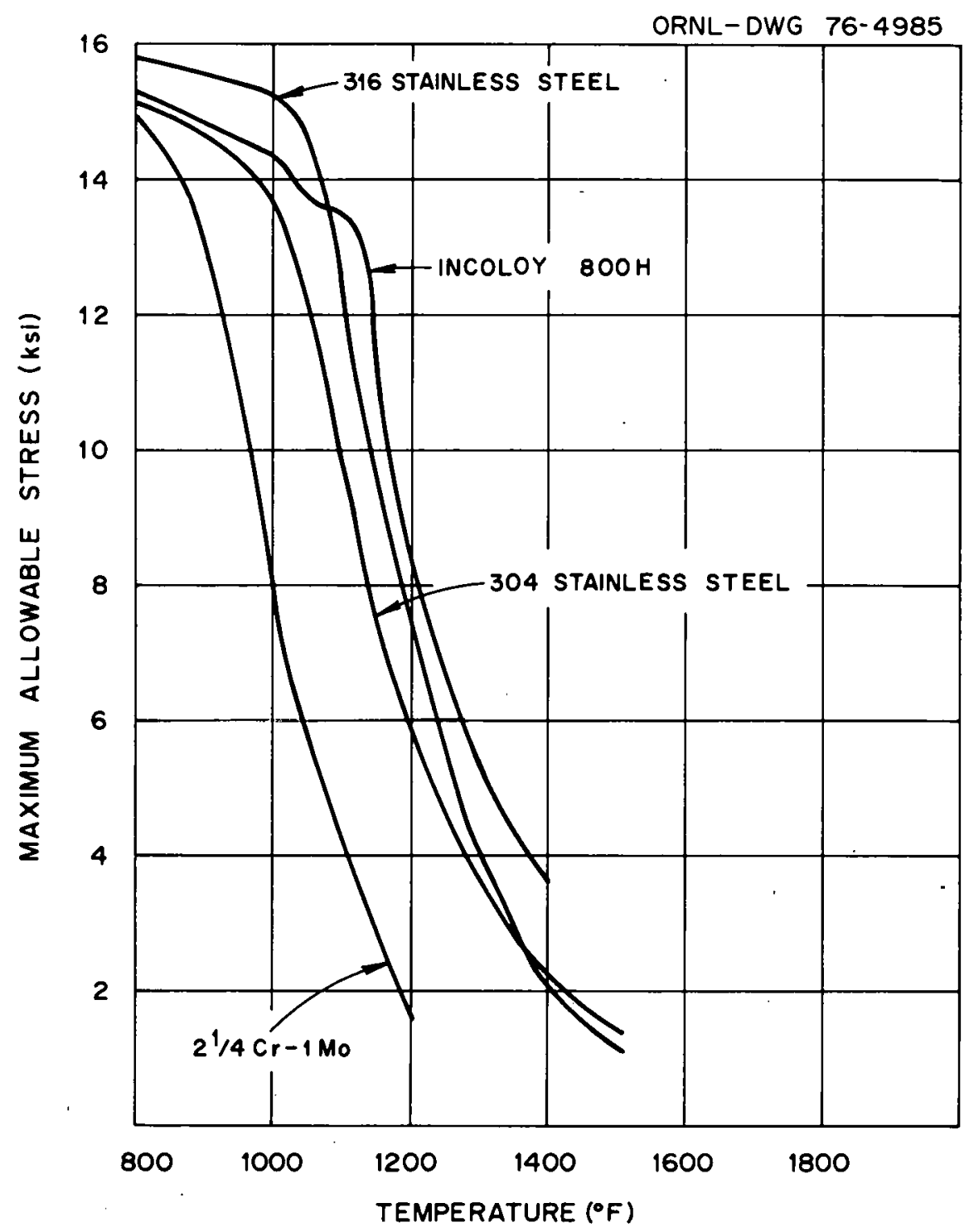

Fig. 31. Maximum allowable stress intensities for Code Case 1592 materials.

excess of $1500^{\circ} \mathrm{F}$. However, extrapolation of the maximum allowable stress limits (Fig. 31) to higher temperature indicates stress intensity limits for these materials at $1600^{\circ} \mathrm{F}$ would be near or below $1000 \mathrm{psi}$. One should be skeptical about recommending a material for a heat exchanger of this size which operates at $1600^{\circ} \mathrm{F}$ and which has stress allowables below 1000 psi.

Since additional alloys can be added to the Code, a review of the creep rupture strength of those candidate materials listed in Table 34 is useful, and such information has been generated by a special task group of the American Iron and Steel Institute (AISI). 65 Data from the 
Larson-Miller extrapolation of 6000- to 40,000-hr creep rupture were used to predict the stress rupture limits at temperatures ranging from $1500^{\circ}$ to $1800^{\circ} \mathrm{F}$ for a variety of materials. This analysis of the Larson-Miller extrapolation of stress rupture behavior for 5- to 30-year service (about 40,000 to $300,000 \mathrm{hr}$ ) indicates that: (1) solutionhardened nickel-base alloy (i.e., Inconel 600, 601, and Incoloy 800) had superior stress rupture properties when compared to stainless steel materials; (2) further improvement in stress rupture properties was observed with centrifugally cast alloys (i.e., HK40 and CF8M); (3) precipitation-strengthened nickel-base alloys (Waspaloy and D979) were stronger than any iron- or nickel-base alloy in the $1300^{\circ}$ to $1600^{\circ} \mathrm{F}$ range (however, above these temperatures these materials over age and rapidly lose strength and ductility); and (4) these data indicated that molybdenum and TZM alloys are candidates for process temperatures of $1700^{\circ}$ to $2200^{\circ} \mathrm{F}$. In conclusion, these data suggest that $1650^{\circ}$ to $1700^{\circ} \mathrm{F}$ could possibly be an upper limit for the use of the nickel-base and centrifugally cast alloys in long-term creep conditions. However, a review of stress rupture properties supplied by Huntington Alloy 66 for a variety of their solid-solution nickel-base alloys did not agree with the special task group's report. The Huntington Alloy data suggest that the stress rupture properties for their alloys are significantly lower than those indicated by the special task group.

Extrapolation of the ASME Code data indicates that stainless steels will not be expected to have sufficient creep rupture strength to be considered candidates for processes at temperatures in excess of $1550^{\circ} \mathrm{F}$. However, design requiring the replacement of tube materials on a threeto five-year basis may allow the use of stainless steel to process temperatures as high as $1600^{\circ} \mathrm{F}$.

In view of the variations in available stress rupture properties and in the high product reliability that will be required in nuclearly associated facilities, an accurate assessment of the upper temperature limit at which nickel-base alloys and centrifugally cast materials could be used cannot be made at this time. However, one would anticipate that use of these materials in designs that will require their replacement on a three- to five-year basis would allow their use at temperatures in excess of those estimated for the stainless steel materials.

\subsection{Materials Compatibility}

The purpose of this section is to review the potential compatibility problems that are expected to affect the service life of the PHX tube materials. This will be done by evaluating separately the corrosion of the randidate materials when exposed to impure helium and process environments.

It has been documented that the helium used as the primary coolant in the high-tempcrature reactor (HTR) contains reactive impurtties such as $\mathrm{H}_{2}, \mathrm{O}_{2}, \mathrm{CO}_{\mathrm{x}}$, and $\mathrm{CH}_{\mathrm{x}}$. The apparent sources of these impurities are out-gassing of the graphite moderator material and in-leakage. Structural and tubing materials exposed to this environment have been subject to' either internal oxidation or internal carburization of selected alloying elements, depending on impurity ratios present in the helium.67,68 
The oxidation potential of materials in the primary coolant stream is related to the $\mathrm{H}_{2}: \mathrm{H}_{2} \mathrm{O}$ ratio. Using the operating temperatures and the range of $\mathrm{H}_{2}: \mathrm{H}_{2} \mathrm{O}$ ratios observed in existing HTR test facilities, one would anticipate that nickel, cobalt, and copper would be reduced in this environment. On the other hand, manganese, chromium, silicon, aluminum, titanium, and niobium would be oxidized, and iron, molybdenum, and tungsten would respond intermediately.

The potential for selective carburization is dependent on the following partial pressure ratios: $\mathrm{P}_{\mathrm{CH}_{4}}: \mathrm{P}_{\mathrm{H}^{2}}$ and $\mathrm{P}_{\mathrm{CO}}^{2}: \mathrm{P}_{\mathrm{CO}^{2}}$. Using the primary helium maximum operating temperature and the range of $\mathrm{CH}_{4}, \mathrm{H}_{2}$, and $\mathrm{CO}_{2}$ observed in existing HTR test facilities, one finds that chromium, titanium, and aluminum would be carburized, whereas nickel, cobalt, and copper would be unaffected.

Note that the above observations are based on operating temperatures and impurity concentrations in the primary helium coolant. However, the secondary coolant will be isolated from the primary loop and will operate at a lower temperature. Since the secondary coolant loop does not contain graphite, the level of $\mathrm{CO}, \mathrm{CO}_{2}$, and $\mathrm{CH}_{\mathrm{X}}$ should be lower. In view of these factors, interactions between PHX materials and the secondary helium coolant should be less severe than those observed in the primary helium loop.

As indicated above, the process environment of both the steam reformer and coal gasification systems is expected to be highly corrosive. These environments will be strongly reducing and contain significant quantities of $\mathrm{CO}, \mathrm{H}_{2}$, and $\mathrm{CH}_{4}$. The coal gasification process will also contain quantities of $\mathrm{H}_{2} \mathrm{~S}$ and abrasive particles of ash and char. A brief description of the anticipated forms of corrosion which may influence the service life of the tube materials in these two systems follows.

- A catastrophic form of carburization of materials used at high temperatures in reducing environments has been encountered in the petroleum industry. 69 This form of carburization is called carbon dusting. It has been found by the petroleum industry that this can be retarded by using iron-chromium-nickel alloys containing nickel in excess of $20 \%$. Additional improvements could be realized with silicon additions up to $2 \%$; however, this level of silicon is not normally possible in wrought alloys but can be realized in centrifugally cast alloys.

Recently, U.S. Steel reported a failure in their Clean Coke process because of carbon dusting. ${ }^{70}$ They noted that type 316 stainless steel, used as a downcomer in the pyrolysis reactor in this system, was carburizing at a rate of $0.25 \mathrm{mil} / \mathrm{hr}$. The situation was rectified by maintaining the $\mathrm{H}_{2} \mathrm{~S}$ content of the system above $10 \mathrm{ppm}$ and by replacing the 316 material with Incoloy 800 .

An analysis of the resistance of a cross section of candidate materials to high-temperature sulfidation is currently being carried out by IITRI. 71 In this program, candidate materials are exposed to environments of $0.01,0.5$, and 1.0 vol\% $\mathrm{H}_{2} \mathrm{~S}$ for $1000 \mathrm{hr}$ at temperatures and pressures of $1800^{\circ} \mathrm{F}$ and $1000 \mathrm{psi}$. Based on preliminary results, a ranking of the materials in terms of their corrosion resistance to these environments (greatest to smallest) would be as follows: (1) $50 \mathrm{Cr}-50$ 
$\mathrm{Ni}$; (2) 308, 310, and 446 stainless steel and Inconel 793; (3) Inconel 601 and Incoloy 800 ; and (4) 304 and 316 stainless steel and Inconel 600. (The last group was found to have undergone considerable corrosion.) A possible compatibility problem that may significantly affect the reliability and durability of tube materials in fluidized-bed coal gasification systems is erosion. Experience with nonpressurized fluidizedbed combustion systems indicates that gas velocities between 2 and 10 fps are required to maintain a fluid bed. Therefore, heat exchanger tubes embedded in a fluidized bed would be exposed to coal, char, and ash particles traveling at these velocities. Note that significantly higher gas velocities can be expected in the product gas piping. Under these conditions, protective surface films can be destroyed by the erosive action, exposing the material to the hostile environment.

At this time, no experimental data are available regarding the erosion-corrosion process in gasification systems. In an effort to correct the situation, EPRI has established a program in which surveillance coupons will be placed in currently operating fluidizedbed systems.72 In addition, Argonne National Laboratory, IITRI, the National Bureau of Standards, and the University of California, Berkeley, are currently assembling test apparatus for the screening of candidate materials under erosion-corrosion conditions similar to those anticipated in coa1-conversion systems.

Nickel-chromium alloys have been observed to undergo severe internal oxidation in service. ${ }^{73}$ In these cases, the alloys become brittle, and the resulting fracture surface appears dark green. This form of attack has occurred primarily at temperatures of $1200^{\circ}$ to $1800^{\circ} \mathrm{F}$ in marginally oxidizing atmospheres where chromium is oxidized and nickel is reduced. In addition, this internal oxidation tends to occur only in combination with carburization or sulfidation corrosion. In the petrochemical industry, this form of attack is often observed in the high-nickel Inconel alloys; however, the presence of $10 \%$ to $15 \%$ iron appears to arrest the attack.

In view of the encouraging stress rupture properties of molybdenum and molybdenum alloys at temperatures of $1700^{\circ}$ to $2000^{\circ} \mathrm{F}$, these materials could be considered possible candidates; therefore, their compatibility characteristics will be considered. Vendor data indicate that molybdenum and molybdenum alloys should not be used in oxidizing conditions above $1000^{\circ} \mathrm{F} .74$ This information further suggests that these materials are not affected by $\mathrm{CO}, \mathrm{CO}_{2}, \mathrm{H}_{2} \mathrm{~S}$, or $\mathrm{H}_{2}$ at temperatures below $2000^{\circ} \mathrm{F}$. The potential for localized variations of conditions (from reducing to oxidizing) in both steam reforming and coal gasification systems makes an assessment of the reliability of molybdenum and molybdenum alloys in these systems difficult.

\subsection{Thermochemical Hydrogen Production}

Westinghouse has proposed a process for the generation of hydrogen by thermochemical water splitting in which a VHTR will supply both the thermal and electrical energy demands of the process. ${ }^{3}$ In this process, 
sulfuric acid saturated with $\mathrm{SO}_{2}$ is pumped through the anodic compartment; acid unsaturated with $\mathrm{SO}_{2}$ is pumped through the cathodic compartment. Hydrogen is liberated at the cathode, and $\mathrm{H}_{2} \mathrm{SO}_{3}$ is oxidized to $\mathrm{H}_{2} \mathrm{SO}_{4}$ at the anode. In the following operation, $\mathrm{H}_{2} \mathrm{O}$ is evaporated in the acid preheater from the aqueous $\mathrm{H}_{2} \mathrm{SO}_{4}$ solution. The concentrated acid is subsequently vaporized in the acid vaporizer and is fed to the decomposition reactor where the $\mathrm{SO}_{3}$ is decomposed to $\mathrm{SO}_{2}$ and $\mathrm{O}_{2}$. Subsequent operations involve the separation of $\mathrm{H}_{2} \mathrm{O}, \mathrm{SO}_{2}$, and $\mathrm{O}_{2}$. Nuclear heat will be required for the sulfuric acid vaporizer and sulfur trioxide reactor. (Figure 32 is a schematic of the system.)

Although significant compatibility problems exist throughout this process, the purpose of this section is to discuss the VHTR process interfaces. As indicated above, these interfaces occur at the sulfur trioxide reduction reactor and at the sulfuric acid vaporizer.

Operating conditions that have been proposed for these two components $^{75}$ are listed in Table 35 .

Table 35. Proposed operating conditions for the sulfur trioxide reduction reactor and sulfuric acid vaporizer

\begin{tabular}{|c|c|c|c|c|}
\hline \multirow[b]{2}{*}{ Unit } & \multirow[b]{2}{*}{ Location } & \multicolumn{3}{|c|}{ Operating conditions } \\
\hline & & $\begin{array}{c}\text { Temperature } \\
\left({ }^{\circ} \mathrm{F}\right)\end{array}$ & $\begin{array}{l}\text { Pressure } \\
\text { (psia) }\end{array}$ & $\begin{array}{l}\text { Composition of } \\
\text { environment } \\
\text { (vol } \%)\end{array}$ \\
\hline $\begin{array}{l}\mathrm{SO}_{3} \text { reduction } \\
\text { reactor }\end{array}$ & $\begin{array}{l}\text { Process stream } \\
\text { input } \\
\text { Process stream } \\
\text { output }\end{array}$ & $\begin{array}{r}800 \\
1600\end{array}$ & $\begin{array}{l}55 \\
45\end{array}$ & $\begin{array}{ll}18 \% & \mathrm{H}_{2} \mathrm{O} \\
82 \% & \mathrm{SO}_{3} \\
12 \% & \mathrm{O}_{2} \\
18 \% & \mathrm{H}_{2} \mathrm{O} \\
48 \% & \mathrm{SO}_{2} \\
2.2 \% & \mathrm{SO}_{3}\end{array}$ \\
\hline & $\begin{array}{l}\text { Helium Input } \\
\text { Helium output }\end{array}$ & $\begin{array}{l}1700 \\
1100\end{array}$ & $\begin{array}{r}1000 \\
980\end{array}$ & $\begin{array}{l}\text { Helium } \\
\text { Helium }\end{array}$ \\
\hline Acid vaporizer & $\begin{array}{l}\text { Process stream } \\
\text { input } \\
\text { Process stream } \\
\text { output } \\
\text { Helium input } \\
\text { Helium output }\end{array}$ & $\begin{array}{l}577 \\
800 \\
900 \\
700\end{array}$ & $\begin{array}{l}\sim 60 \\
55 \\
65 \\
50\end{array}$ & $\begin{array}{l}\text { Concentrated } \\
\mathrm{H}_{2} \mathrm{SO}_{4} \\
18 \% \mathrm{H}_{2} \mathrm{O} \\
82 \% \mathrm{SO}_{3} \\
\text { Hel1um } \\
\text { Helium }\end{array}$ \\
\hline
\end{tabular}

Later estimates indicate that the acid vaporizer components could operate in an environment of concentrated $\mathrm{H}_{2} \mathrm{SO}_{4}$ at pressures of 50 to $125 \mathrm{psig}$ and temperatures of $150^{\circ}$ to $620^{\circ} \mathrm{F}$. Generally, materials that could be expected to withstand these conditions are the noble metals gold, platinum, and tantalum - and high-silicon alloys such as Duriron and Hastelloy D. A discussion of the usefulness of these materials in these process conditions follows. 


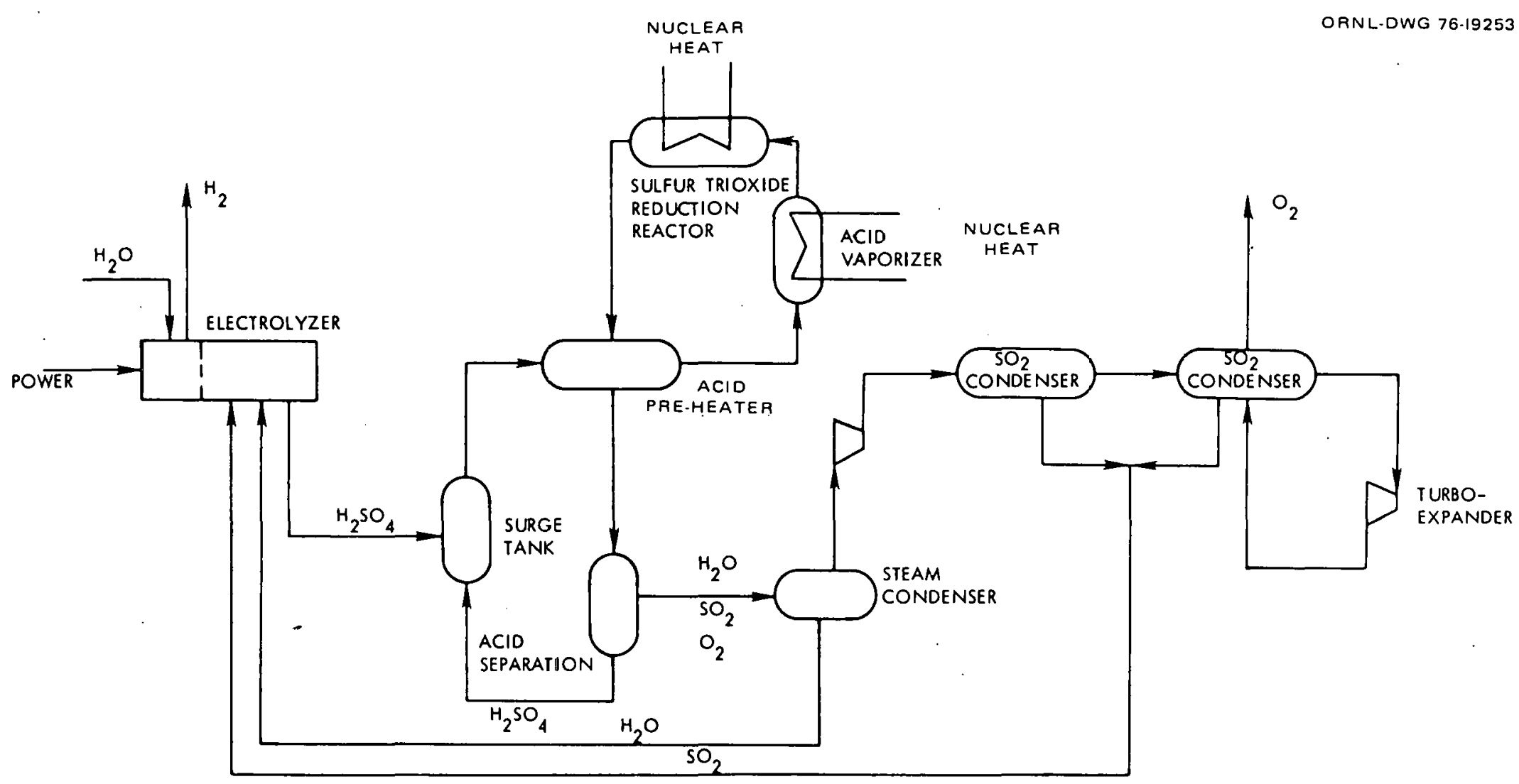

Fig. 32. Sulfur cycle schematic flowsheet. 
Obviously, the use of gold, platinum, or tantalum as heat exchanger tubing would be economically prohibitive. Furthermore, the economics of plating or lining a less resistant metal with platinum or gold has been reviewed recently by $U E \& C .75$ This effort indicated that even a 1-milthick coating would be prohibitive at today's prices.

Tantalum, on the other hand, is not as expensive as gold and platinum and is being used by the chemical industry as tube liners for the evaporation of $\mathrm{HCl}, \mathrm{HNO}_{3}$, and $\mathrm{H}_{3} \mathrm{PO}_{4}$. Although the use of tantalum is limited by its susceptibility to hydrogen embrittlement at temperatures above $750^{\circ} \mathrm{F}$, this should not be a restriction in the thermochemical hydrogen process. Therefore, a careful economic analysis should be made of the potential for using tantalum and tantalum alloys as tube liners in the acid vaporizer.

The next group of potential candidate materials is those utilizing the corrosion resistance of silicon. One candidate from this group is Duriron, a $14.5 \%$ silicon, $85 \%$ iron castable alloy. Vendor data suggest that corrosion rates for Duriron in $80 \% \mathrm{H}_{2} \mathrm{SO}_{4}$ at temperatures up to $430^{\circ} \mathrm{F}$ are below 1 mil per year. In addition, corrosion rates less than 1 mil per year were observed in $98.3 \% \mathrm{H}_{2} \mathrm{SO}_{4}$ at temperatures as high as $640^{\circ} \mathrm{F}$. These data further show that sulfur dioxide dissolved in either water or sulfuric acid corrodes Duriron at a rate of 1000 mils per year; however, the addition of $4.5 \%$ chromium to Duriron reduces this corrosion rate to 4 mils per year. With the chromium addition, the alloy is sold as Durichlor 51 or Superchlor. A summary of the nominal composition and properties of Duriron and its related alloys is listed in Tables 36 and 37. A review of the properties reveals that these materials have several significant limitations with regard to mechanical properties and thermal shock characteristics. Because of the brittleness of this material, operation at differential pressures in excess of $50 \mathrm{psi}$ is not recommended. Furthermore, Duriron castings are virtually unmachinable and can be welded only with difficulty. At present, Duriron can be cast only into 1-in. $x$ 3-ft tubes or into 1/2-in. x 6-ft $\times$ 8-ft sheets; therefore, use of this material in a conventional shell-and-tube heat exchanger is not practical. United Engineers and Constructors, however, has recommended the use of this material in plate-type heat exchangers.

Table 36. Nominal composition of Duriron-type alloys and of Hastelloy D

\begin{tabular}{lcccc}
\hline & \multicolumn{3}{c}{ Alloy (\%) } \\
\cline { 2 - 5 } Element & Duriron & Durichlor 51 & Superchlor & Hastelloy D \\
\hline Silicon & 14.5 & 14.5 & 14.5 & 8.5 to 10.0 \\
Carbon & 0.85 & 0.85 & 0.85 & 0.12 to 1.25 \\
Manganese & 0.65 & 0.65 & 0.65 & 0.5 to \\
Chromium & & 4.50 & 4.50 & 1.0 \\
Iron & Balance & Balance & Balance & 2.0 \\
Cobalt & & & & 1.5 \\
Copper & & & & 2.0 to 4.0 \\
\hline
\end{tabular}


Table 37. Ncminal properties of Duriron-type alloys and of Hastelloy D

\begin{tabular}{|c|c|c|c|c|}
\hline \multirow[b]{2}{*}{ Property } & \multicolumn{4}{|c|}{ A11oy } \\
\hline & Duriron & Durichlor 51 & Superchlor & Hastelloy D \\
\hline Tensile strength, psi & 16,000 & 16,000 & 29,000 & 115,000 \\
\hline Elongation, \% & 0 & 0 & 0 & 1 \\
\hline Reduction of area, $\%$ & 0 & 0 & 0 & 1 \\
\hline Hardness, Brinell & 520 & 520 & 520 & 360 \\
\hline Compression strength, psi & 100,000 & 100,000 & 100,000 & \\
\hline Specific gravity & 7.0 & 7.0 & 7.0 & 7.8 \\
\hline Melting point, ${ }^{\circ} \mathrm{F}$ & 2,300 & 2,300 & 2,300 & 2,065 to 2,220 \\
\hline
\end{tabular}


Despite these numerous limitations, Duriron-type materials continue to be used in the chemical processing industry. With regard to the thermochemical hydrogen process, the Durichlor 51 material should be considered a candidate material for the acid vaporizer.

Hastelloy $\mathrm{D}$ is another high-silicon alloy (10\% $\mathrm{Si}$ ) which appears to be a candidate for use in the acid vaporizer. A review of the corrosion resistance of Hastelloy D in sulfuric acid (Table 38) reveals that this material is resistant to the acid at all concentrations at temperatures up to the normal boiling point of the acid. The vendor indicates that the alloy develops maximum resistance to corrosion after a six-week exposure. ${ }^{76}$ During this period a protective sulfate film is thought to form. Tables 36 and 37 summarize the physical and mechanical properties of Hastelloy D. These data suggest that Hastelloy D may have improved strength and toughness when compared to the Duriron materials. Although Hastelloy $D$ is available as a centrifugal casting, it does not appear to be any easier to weld than Duriron. In view of its availability in tube shapes and improved toughness, Hastelloy D should be considered a candidate for the thermochemical process.

Table 38. Corrosion rates of Hastelloy D in sulfuric acid

\begin{tabular}{ccccc}
\hline $\begin{array}{c}\text { Concentration of } \\
\text { sulfuric acid } \\
(\text { wt \%) }\end{array}$ & $\begin{array}{c}\text { Penetration } \\
\text { temperature }\end{array}$ & $150^{\circ} \mathrm{F}$ & $\begin{array}{c}\text { Normal } \\
\text { boiling } \\
\text { point }\end{array}$ & $\begin{array}{c}\text { Boiling } \\
\text { temperature } \\
\left({ }^{\circ} \mathrm{F}\right)\end{array}$ \\
\hline 2 & 1 & 6 & 4 & 212 \\
5 & 1 & 5 & 7 & 212 \\
10 & 1 & 5 & 13 & 212 \\
25 & 1 & 2 & 9 & 224 \\
50 & 1 & 1 & 11 & 264 \\
60 & 1 & 6 & 8 & 291 \\
77 & 3 & 2 & 29 & 383 \\
80 & 1 & 2 & 36 & 395 \\
85 & 1 & 2 & 91 & 450 \\
90 & 1 & 2 & 191 & 510 \\
96 & 1 & 1 & 86 & 604 \\
\hline
\end{tabular}

Table 35 indicates that the $\mathrm{SO}_{3}$ reduction reactor is currently designed to operate at a helium inlet temperature of $1700^{\circ} \mathrm{F}$ and with a pressure differential up to 955 psi across the heat exchanger wall. Based on the discussion of the high-temperature load-carrying capability of tube materials for the steam reforming and coal gasification systems, 
the proposed operating conditions for the $\mathrm{SO}_{3}$ reduction reactor do not appear to be realistic. As indicated earlier, $1650^{\circ}$ to $1700^{\circ} \mathrm{F}$ appears to be the upper limit for use of conventional alloys in heat exchangers designed to operate under balanced pressure conditions. Redesign of the $\mathrm{SO}_{3}$ reduction reaction to operate with a balanced pressure and with an anticipated heat exchanger tube life of five years would make this system more realistic with respect to material strength limitations.

A review of Table 35 further indicates that the heat exchanger tube material within the sulfur trioxide reactor will be exposed to an environment consisting principally of $\mathrm{SO}_{2}$ and $\mathrm{SO}_{3}$ and containing lesser concentrations of $\mathrm{O}_{2}$ and $\mathrm{H}_{2} \mathrm{O}$. Generally, those alloys having the necessary creep strength to be considered for this application will have sufficient levels of nickel and chromium to resist corrosion by the $\mathrm{O}_{2}$ and $\mathrm{H}_{2} \mathrm{O}$ in this environment. However, the $\mathrm{SO}_{2}$ and $\mathrm{SO}_{3}$ could have a more significant impact on the corrosion rates of the tube materials. For iron-chromium-nickel alloys, the best corrosion resistance to $\mathrm{SO}_{2}$ and $\mathrm{SO}_{3}$ is obtained with high-chromium contents and with nickel levels below 35\%. Nickel content in excess of this amount tends to decrease the resistance to sulfur attack. Alloys with $20 \%$ chromium or less offer little resistance and are rapidly deteriorated. These criteria suggest that Incoloy 800 is marginally acceptable. Centrifugally cast alloys such as HK40 and Supertherm appear to be good candidates for this application both in terms of corrosion and strength properties.

\subsection{Summary}

The preceding has been an analysis of the high-temperature loadcarrying capability and compatibility characteristics of a cross section of materials which could be considered as PHX tube materials in the steam reforming, steam-coal gasification, and Westinghouse thermochemical hydrogen processes. A summary of significant observations follows.

1. Extrapolation of stress intensity limits for Code Case 1592 materials suggests that design stress allowables for stainless steels at temperatures above $1550^{\circ} \mathrm{F}$ will be too low to allow reliable long-term use.

2. A revision of the Code to allow designs of components with three- to five-year lifetimes could increase the range of temperature utilization for stainless steels to $1600^{\circ} \mathrm{F}$. However, the impact of taking this step for the steam reformer, steam-coal gasifier, and $\mathrm{SO}_{3}$ reduction reactor may be economically unacceptable.

3. Due to the wide variation in extrapolations of stress rupture properties for solid-solution nickel alloys alld centrifugally cast materials at the proposed process operating temperatures, an assessment of the maximum temperature at which these materials can be used reliably cannot be made at this time. 
4. In the proposed steam reformer environment, catastrophic failure of the PHX tube material by carburization and metal dusting is possible. The use of catalyst tube materials having high levels of nickel and silicon (i.e., HK40) has reduced the frequency of this type of failure in the petroleum industry.

5. Erosion and sulfidation effects are expected to influence the service life of PHX tube materials in the steam-coal gasification process. Currently, however, no experimental data are available to allow an assessment of the effect of erosion in this process. Preliminary sulfidation experiments conducted at IITRI suggest that, of the candidate materials being considered, 310 and 314 stainless steel, Inconel 601, and Incoloy 800 are more resistant to sulfidation than are 304 and 316 stainless steel and Incone1 600 .

6. Heat exchanger materials in the acid vaporizer component of the Westinghouse thermochemical process are expected to be in an environment of concentrated sulfuric acid at temperatures of $620^{\circ}$ to $800^{\circ} \mathrm{F}$. Gold and platinum could be used to resist corrosion in this environment, but the cost of these materials makes their use prohibitive; thus, tantalum is more attractive. High-silicon alloys such as Duriron and Hastelloy D may have sufficient corrosion resistance, but their poor fabrication and low ductility suggest marginal use in this application. 


\section{REFERENCES}

1. General Atomic Company, High-Temperature Nuclear Heat Source Study, GA-A13158, Dec. 30, 1974.

2. General Electric Company, The VHTR for Process Heat (Draft), vols. I and II, GEAP-14018, September 1974.

3. Westinghouse Astronuclear Laboratory, Westinghouse Electric Corporation, The Very High Temperature Reactor for Process Heat, WANL-2445-1, December 1974.

4. I. Spiewak et al., Assessment of Very High Temperature Reactors in Process Applications, ORNL/TM-5242, Oak Ridge National Laboratory, Oak Ridge, Tenn., November 1976.

5. Office of the Minister für Wirtschaft, Mittelstand und Verkehr des Landes Nordrhein-Westfalen, Dusseldorf, Gasification of Coal with Nuclear Process Heat, translated by R. G. Mansfield, ORNL/tr-4002, Oak Ridge National Laboratory, Oak Ridge, Tenn., July 1974.

6. Stone \& Webster and. General Atomic Company, Firul Report Application Study of a Nuclear Coal Solution Gasification Process for Oklahoma Coal, vols. I and II, OCR-RDR-86, May 1972.

7. General Atomic Company, Studies of the Use of High-Temperature Nuclear Heat from a HTGR for Hydrogen Production, GA-A13391, prepared under contract for NASA, Sept. 30, 1975.

8. J. J. Williams et al., Evaluation of a Coal Liquefaction Process Using Either a Nuclear or Fossil Heat Source, UE\&C/UCC-760223, United Engineers \& Constructors, February 1976.

9. GA HTGR Concept for $1600^{\circ} \mathrm{F}$ Process Temperature, ERDA/NASA Information Meeting, Use of VHTR for Process Heat, Washington, D.C., June $6,1975$.

10. H. Juentgen et al., "Kinetics, Heat lransfer, and Engineering Aspects of Coal Gasification with Steam Using Nuclear Heat," session III of British Nuclear Energy Society International Conference, The High Temperature Reactor and Process Applications, November 1974, London, p. 12.

11. K. H. Van Heek, H. Juentgen, and W. Peters, "Fundamental Studies on Coal Gasification in the Utilization of Thermal Energy from Nuclear High Temperature Reactors," J. Inst. Fuel, pp. 249-58 (June 1973).

12. A. M. Squires, "Steam-Oxygen Gasification of Fine Sizes of Coal in a Fluidized Bed at Elevated Pressure," Parts I-III, Trans. Inst. Chem. Eng. 39 (1961). 
13. S. P. Chauhan et al.; (Hydro) Gasification of Battelze Treated Coal (BTC), 1975.

14. C. Y. Wen and 0. C. Abraham, "A Kinetic Study of the Reaction of Coal Char with Hydrogen-Steam Mixtures," Fuel Gasification, Advances in Chemistry, Series G9, American Chemical Society, 1969.

15. J. D. Blackwood and F. McGrary, "The Carbon-Steam Reaction at High Pressure," Aust. J. Chem. 11: 16 (1958).

16. H. C. Hottel and J. B. Howard, New Energy Technology, MIT Press, Cambridge, Mass., 1971.

17. C. G. Von Fredersdorff and M. A. Elliott, "Coal Gasification," Chap. 20 in Chemistry of Coal Utizization, H. H. Lowry, ed., supp1. vol., John Wiley \& Sons, Inc., New York, 1963.

18. Personal communication, John E. Jones, Oak Ridge National Laboratory, Oak Ridge, Tenn., February 1976.

19. J. J. Williams et al., Evaluation of a Coal Liquefaction Process Using Either a Nuclear or Fossil Heat Source, UE\&C/UCC-760223, February 1976, pp. 27-28.

20. California Institute of Technology, Jet Propulsion Laboratory, Hydrogen Tomorrow: Demands and Technology Requirements, Review Draft, 5040-I, Oct. 30, 1975.

21. Westinghouse Astronuclear Laboratory, Studies of the Use of Heat from High Temperature Nuclear Sources for Hydrogen Production Processes (Draft Final Tasks I and II Report), NAS 3-18934, July 1975 .

22. Institute of Gas Technology, Survey of Hydrogen Production and Utilization Methods, vol. 1, Executive Summary, NAS 8-30757, prepared for NASA, Huntsville, Alabama, August 1975.

23. M. G. Bowman, "Fundamental Aspects of Systems for the Thermochemical Production of Hydrogen from Water," p. 251 in Proceedings of First National Topical Meeting on Nuclear Process Heat Applications, Los Alamos, New Mexico, October 1-3, 1974, LA-5795-C, November 1974.

24. Personal communication, C. E. Bamberger and J. Braunstein to I. Spiewak, Oak Ridge National Laboratory, Oak Ridge, Tenn., June $16,1975$.

25. Institute of Gas Technology, A Preliminary Systems-Engineering Study of an Advanced Nuclear-Electrolytic Hydrogen Production Facility, NAS 8-30757, prepared for NASA Marshall Space Flight Center. 
26. D. M. Mitsak and J. F. Kamody, "Koppers-Totzek: Take a Long Hard Look," p. 36 in Proceedings of Second Annual Symposizm on Coal Gasification, Liquefaction, and Utilization: Best Prospects for Commercialization, Pittsburgh, Pennsylvania, August 5-7, 1975.

27. General Electric Company, The VHTR for Process Heat, vol. I, GEAP-14018, September 1974, Pp. 1-15.

28. Dow Chemical Company, New Energy Sources for Process Heat, report to the National Science Foundation, June 1975, p. 68.

29. National Petroleum Council, U.S. Energy Outlook: Coal Availability, 1973, Appendix 0, pp. 249-87.

30. J. C. Gillis et al., Survey of Hydrogen Production and UtiZization Methods, vol. 2, Institute of Gas Technology, August 1975, pp. 343-76.

31. Llewellyn King, ed., Weekly Energy Report, July 15, 1974, pp. 6-7.

32. W. G. Dupree, Jr., and J. S. Corsentino, United States Energy Through the Year 2000 (Revised), U.S. Department of the Interior, Bureau of Mines, December 1975.

33. United Engineers \& Constructors Inc., An Evaluation of Pollution and Water Consumption by Selected Coal Conversion Processes, February 1976 .

34. D. J. Blickwede and T. F. Barnhart, "The Use of Nuclear Energy in Steelmaking - Prospects and Plans," Proc. First National Topical Meeting on Nuclear Process Heat Applications, Los AZamos, New Mexico, October 1-3, LA-5795-C, November 1974, p. 169.

35. American Iron and Steel Institute, PZanning Document - A Materials Evaluation and Testing Program for the VHTR/Reformer Process Heat System, American Iron and Steel Institute, Washington, D.C., submitted to Energy Research and Development Administration, May 1975 .

36. American Iron and Steel Institute, Report of the Concepts Working Group of the AISI Task Force on Nuclear Steelmaking, American Iron and Steel Institute, August 1975.

37. R. N. Quade, Chairman, General Atomic, Report of the Reformer Working Group of the HTGR Nuclear Steelmaking Group, August 1975.

38. D. J. Blickwede, Nuclear Steelmaking - Prospects in the USA (Bethlehem Steel Company) transmitted to Association of Iron and Steel Engineers, September 22, 1975. 
39. T. F. Barnhart, Chairman, U.S. Steel Corporation, Report of the Technical and Economic Evaluation Working Group, September 1975.

40. J. J. Williams and J. B. Newman, Engineering Evaluation of Process Heat Applications for Very High Temperature Nuclear Reactors, UE\&C-ERDA-750630 (Revised), February 1976.

41. H. Murata, "Design and Development of an HTGR for Multi-Purpose Utilization in Japan, Japan Atomic Energy Research Institute, Proc. First National Topical Meeting on Nuclear Process Heat Applisations, Los AZcomos, New Mexico, October 1974, LA-5795-C, November 1974, p. 136 .

42. J. Huntsinger et al., Process Heat in Petroleum Refinery Applications - Final Report, GA-A13406. (Revised), General Atomic Company, February 1976.

43. Resource Analysis and Management Group, An Evaluation of the Very High Temperature Reactor (VHTR) as an Energy Source for Tar Sand and Oil Shale Recovery and Processing, Resource Analysis and Management Group, Oklahoma City, prepared for Oak Ridge National Laboratory, June 1975.

44. R. E. Hanneman et al., Closed Loop Chemical Systems for Energy Transmission, Conversion and Storage, 74CRD-211, General Electric Company, September 1974.

45. R. Schulton et a1., Chemical Latent Heat for Transport of Nuclear Energy Over Long Distances, BNES International Conference, November 1974 .

46. J. G. Delene, personal communication with E. C. Fox, Oak Ridge National Laboratory, Hebruary $1 y / 6$.

47. Federal Energy Administration, Project Independence, November 1974.

48. Energy Research and Development Administration, A National Plan for Energy Research Development and Demonstration: Creating Energy Sources for the Future, vol. 1, The Plan, ERDA-48, June 1975.

49. M. H. Lietzke, personal communication with L. C. Fuller, E. C. Fox, Oak Ridge National Laboratory, Oak Ridge, Tenn., November 1975.

50. K. Kugeler et al., The Pebble Bed High Temperature Reactor as $A$ Source of Nuclear Process Heat, vol. 4, a common study by Kernforschunganlage, Julich, Germany and the General Electric Company, August 1974 .

51. United Engineers and Constructors, 770 MWe Central Station Power Plants Investment Cost Study, vol. V, High 'l'emperature Gas-Cooled Reactor Plant, USAEC Report WASH-1230 (vol. I), 1973. 
52. American Gas Association, A Hydrogen Energy System, August 1972.

53. CONCEPT - A Computer Code for Conceptual Cost Estimates of SteamElectric Power Plants, Phase IV User's Manual, ERDA-108.

54. F. Abidi, "Pipeline System Costs Estimated," OiZ Gas J. 99 (October 13, 1975).

55. ORCOST II - A Computer Code for Estimating the Cost of Power from Steam Electric Power Plants, ERDA-76-38.

56. D. W. Allen and W. H. Yen, "Methanator Design and Operation," Chem. Eng. Prog. 69(1): 75-79 (January 1973).

57. E. G. Bohlman, Heat Transfer Salt for High Temperature Steam Generation, ORNL/TM-377 Oak Ridge National Laboratory, Oak Ridge, Tenn., December 1972 .

58. H. P. Voznick and V. W. Uh1, "Molten Salt Heat for Heat Transfer," Chem. Eng. 70: 129 (May 27, 1963).

59. A. A. Bruhn, "Capital Costs Trimmed by $20 \%$ by Heat Transfer Process," Chem. Process. 33(8): 15-30 (August 1970).

60. J. Freedman and A. A. Bruhn, "Diluted Salt Transfers Heat," Oiz Gas J. 76 (1970).

61. E. I. duPont de Nemours and Company, DuPont Hitec ${ }^{R}$ Heat Transfer Salt, E. I. duPont de Nemours and Company, Explosives Department, Chemical Products Sales Division, Wilmington, Deleware.

62. American Hydrotherm Corporation, Hydrotherm Molten SaZt Heat Transfer System, American Hydrotherm Corporation, 470 Park Avenue, South, New York, N.Y.

63. V. W. UhI and H. P. Voznick, "High Temperature Heating Media," Chem. Eng. Prog. 59(5): 33 (May 1963).

64. Rudolf Schulten and Kurt Kugeler, "Coal Gasification and Other Nuclear Process Heat Applications," Proceedings of First. National Topical Meeting on Nuclear Process Heat Applications, Los Alomos, N.M., Oct. 1-3, 1974, LA-5795, November 1974, p. 210.

65. The American Iron and Steel Institute, Planning Document - A Materials Evaluation and Testing Program for the VHTR/Reformer Process Heat System, Washington, D.C. (submitted to ERDA, May 1975).

66. Huntington Alloy Products Division, Huntington AZZoys Technical Buzletin, Huntington, W. Va. 
67. F. N. Mazandarany, Effects of Elevated Temperature Exposure to a Simulated HTGR Primary Coolant Environment on Several Unstressed Austenitic AlZoys, General Atomic, GA-A13462, August 1975.

68. D. S. Wood, M. Farrow, and W. T. Burke, "A Preliminary Study of the Effect of Helium Environment on the Creep and Rupture Behavior of Type 316 Stainless Steel and Incoloy 800," Effects of Environment on Material Properties in Nuclear Systems, British Nuclear Energy Society Conference on Corrosion, 1971, pp. 213-20.

69. I. Koszman, "Factors Affecting Catastrophic Carburization (Metal Dusting)," Proc. High Temperature Gas-Metal Reaction in Mixed Environments, AIME, May 9-10, 1972.

70. USS Engineers and Consultants, Inc., Clean Coke Process - Summary of Bench Scale Studies, Interim Report for March 1972-Apri1 1974, USS-INT-001.

71. Vern Hil1, Materials Properties Council Mtg., Illinois Institute of Technology Research Institute, August 1975.

72. Electric Power Research Institute, Technical Division Progress Report, Fossil Fuel and Advanced Systems Division, Palo Alto, Calif., July 1975 .

73. F.'S. Lang and H. R. Copson, "Some Experiments on Internal Oxidation of Ni-Cr Alloys," Corrosion 15: 196 (1959).

74. J. Z. Briggs and M. G. Manzone, Less Comonon AlZoys of Molybdenum, Technical Bulletin, Climax Molybdenum Company, 1962.

75. Conversation with D. M. Axelrod, United Engineers and Constructors Inc., Philadelphia, Pa., November 1975.

76. Cabot-Stellite Division of-Cabot Corporation, "Technical Bulletin (A1loy Production)," 1974 . 
ORNL/TM-5410

\section{INTERNAL DISTRIBUTION}

$\begin{array}{ll}\text { 1. T. D. Anderson } \\ \text { 2. } & \text { S. Baron } \\ \text { 3. J. H. Coobs } \\ \text { 4. } & \text { R. H. Cooper } \\ \text { 5. W. E. Cooper } \\ \text { 6. } & \text { F. L. Culler } \\ \text { 7. } & \text { J. G. Delene } \\ \text { 8. J. R. DiStefano } \\ \text { 9. } \text { W. P. Eatherly } \\ \text { 10. M. S. Edwards } \\ \text { 11. J. R. Engel } \\ \text { 12. G. G. Fee } \\ \text { 13. } \\ \text { E. C. Fox } \\ \text { 14. L. C. Fuller } \\ \text { 15. W. R. Gambill } \\ \text { 16. M. J. Gog1ia } \\ \text { 17. J. F. Harvey } \\ \text { 18. } & \text { H. W. Hoffman } \\ \text { 19. } & \text { F. J. Homan } \\ \text { 20. J. E. Jones, Jr. } \\ \text { 21. } & \text { P. R. Kasten }\end{array}$

22. 0. H. Klepper

23. M. Levenson

24. C. C. Littlefield

25. R. E. MacPherson

26. A. P. Malinauskas

27. W. J. McCarthy, Jr.

28. J. P. Nichols

29. H. Postma

30. M. W. Rosenthal

31. T. H. Row

32. M. D. Silverman

33-125. I. Spiewak

126. J. J. Taylor

127. D. B. Trauger

128. G. D. Whitman

129. W. J. Wilcox

130. ORNL Patent Office

131-132. Central Research Library

133. Document Reference Section

134-135. Laboratory Records Department

136. Laboratory Records (RC)

\section{EXTERNAL DISTRIBUTION}

137. Director, Division of Fossil Energy Research, ERDA, Washington, D.C. 20545

138. Assistant Administrator for Fossil Energy, ERDA, Washington, D.C. 20545

139. Director, Division of Coal Conversion and Utilization, ERDA, Washington, D.C. 20545

140. Mayo Carrington, Division of Coal Conversion and Utilization, ERDA, Washington, D.C. 20545

141. R. E. Vener, Division of Coal Conversion and Utilization, ERDA Washington, D.C. 20545

142. Fred Witmer, Division of Coal Conversion and Utilization, ERDA, Washington, D.C. 20545

143. Director, Division of Nuclear Research and Applications, ERDA, Washing ton, D.C. 20545

144. T. Beresovski, Division of Nuclear Research and Applications, ERDA, Washington, D.C. 20545 
145. D. E. Erb, Division of Nuclear Research and Applications, ERDA, Washington, D.C. 20545

146. K. 0. Laughon, Division of Nuclear Research and Applications, ERDA, Washington, D.C. 20545

147. J. C. Montgomery, Division of Nuclear Research and Applications, ERDA, Washington, D.C. 20545

148. R. G. Oehl, Division of Nuclear Research and Applications, ERDA, Washington, D.C. 20545

149. J. H. Swisher, Division of Conservation Research and Technology, ERDA, Washington, D.C. 20545

150. A. T. McMain, General Atomic Co., P.0. Box 81608, San Diego, Calif. 92138

151. R. N. Quade, General Atomic Co., P.0. Box 81608, San Diego, Calif. 92138

152. G. H. Farbman, Westinghouse Electric Corp., Astronuclear Laboratory, P.O. Box 10864, Pittsburgh, Pa. 15236

153. A. R. Jones, Westinghouse Electric Corp., Astronuclear Laboratory, P.0. Box 10864, Pittsburgh, Pa. 15236

154. A. E. Kakretz, General Electric Co., Fairfield, Conn. 06431

155. 0. G. Woike, General Electric Co., P.0. Box 15132, Cincinnati, Ohio 45215

156. J. H. Crowley, United Engineers \& Constructors, 1401 Arch St., Philadelphia, Pa. 19105

157. J. B. Newman, United Engineers \& Constructors, 1401 Arch St., Philadelphia, Pa.' 19105

158. D. J. Blickwede, Bethlehem Steel Corp., Bethlehem, Pa. 18016

159. T. F. Barnhart, U.S. Steel Corp., 125 Jamison Lane, Monroeville, $\mathrm{Pa} .15146$

160. H. W. Paxton, U.S. Steel Corp., 125 Jamison Lane, Monroeville, Pa. 15146

161. R. W. Wendes, Amoco Oil Co., Box 6110A, Chicago, Ill. 60680

162. D. C. Azbill, Shell Oil Co., One Shell Plaza, P.0. Box 2463, Houoton, Tox. 77001

163. F. M. Richmond, Universa1-Cyclops, 650 Washington Rd., Pittsburgh, $\mathrm{Pa}$. 15228

164. Derek Gregory, Institute of Gas Technology, 3424 South State St., Chicago, I11. 60616

165. R. J. Jiacoletti, Los Alamos Scientific Laboratory, P.0. Box 1663, Los Alamos, N.M. 87544

166. Donald Bogart, National Aeronautics and Space Administration, 6390 Nelwood Rd.; Cleveland, Ohio 44135

167. D. R. Stone, National Aeronautics and Space Administration, Washington, D.C. 20546

168. Jack G. Connors, Battelle-Columbus Laboratory, 505 King Ave., Columbus, Ohio 43201

169. F. E. Faris, Interdevelopment, Inc., Suite 1014, Rutherford B. Hayes Bldg., 2361 S. Jefferson Davis Hwy., Arlington, Và. 22202

170. Seymour Alpert, Electric Power Research Institute, 3412 Hillview Ave., Palo Alto, Calif. 94304 
171. A. Flowers, American Gas Association, 1515 Wilson Blvd., Arlington, Va. 22209

172. W. C. Helt, National Coal Association, 1103 17th St., NW, Washington, D.C. 20036

173. W. W. Talley, Resource Analysis \& Management Group, 2500 First National Center, Oklahoma City, Okla. 73102

174. Don Crego, Gilbert Associates, 525 Lancaster Ave., Reading, Pa. 19603

175. M. Steinberg, Brookhaven National Laboratory, Upton, N.Y. 11973

176. Engineering Technology Division, ORO, Oak Ridge, Tenn. 37830

177. Research and Technical Support Division, ORO, Oak Rídge, Tenn. 37830

178-204. Technical Information Center, Oak Ridge, Tenn. 37830 